ALEXANDRE MAGNO PARENTE DA ROCHA

\title{
IDENTIFICAÇÃO NEBULOSA DA CONCENTRAÇÃO DE OXIGÊNIO DISSOLVIDO DO TANQUE DE AERAÇÃO DE UMA ESTAÇÃO DE TRATAMENTO DE ESGOTOS POR LODOS ATIVADOS
}

Dissertação apresentada à Escola Politécnica da Universidade de São Paulo para obtenção do título de Mestre em Engenharia

São Paulo

Fevereiro/2003 
ALEXANDRE MAGNO PARENTE DA ROCHA

\section{IDENTIFICAÇÃO NEBULOSA DA \\ CONCENTRAÇÃO DE OXIGÊNIO \\ DISSOLVIDO DO TANQUE DE}

AERAÇÃO DE UMA ESTAÇÃO DE

TRATAMENTO DE ESGOTOS POR

LODOS ATIVADOS

Dissertação apresentada à Escola Politécnica da Universidade de São Paulo para obtenção do título de Mestre em Engenharia

Área de Concentração: Engenharia de Sistemas Orientador: Prof. Dr. Cláudio Garcia

São Paulo

Fevereiro/2003 


\section{AGRADECIMENTOS}

Agradeço primeiramente ao Criador de tudo que existe nesse mundo, o responsável pela inteligência humana, DEUS.

Agradeço também aos meus pais e a minha esposa pelo incentivo recebido durante todo o tempo de desenvolvimento deste trabalho.

À doutoranda Rosimeire Aparecida Jerônimo e ao aluno de graduação do LAC Carlos Eduardo Neri de Oliveira pela ajuda imprescindível na execução das simulações.

Ao meu orientador, Prof ${ }^{\circ}$ Dr. Claudio Garcia, pela paciência e sugestões que foram de grande valia.

Um agradecimento especial à Companhia de Saneamento Básico do Estado de São Paulo (Sabesp), pela inspiração e incentivo do trabalho.

E não poderia deixar de agradecer ao povo trabalhador do estado de São Paulo que além de ter me acolhido em sua terra, proporcionou a oportunidade de que eu pudesse concluir mais uma etapa de meu crescimento humano. 


\section{Resumo}

As estações de tratamento de esgotos por lodos ativados são caracterizadas por modelos cinéticos de comportamento não linear de difícil parametrização. A utilização de técnicas de identificação paramétricas para a modelagem de tais estações produz modelos com parâmetros sem significado operacional e variantes no tempo. Por outro lado, a lógica nebulosa permite ao usuário de modelos baseados em tal técnica uma parametrização mais próxima do raciocínio humano. A facilidade da parametrização nebulosa reside na atribuição de valores lingüísticos às variáveis de entrada do modelo.Esta dissertação utiliza técnicas de modelagem nebulosa, como ANFIS e regras limitadas, para identificar o comportamento da concentração de oxigênio dissolvido do tanque de aeração do benchmark de uma planta de tratamento de esgotos por lodos ativados com remoção de nitrogênio.

\section{Abstract}

Activated sludge wastewater treatment plants are characterized by kinetic models of highly nonlinear behavior, whose time varying parameters are very difficult to calibrate. The use of parametric identification techniques to build models of such plants results in models with parameters without operational meaning.. Alternatively, the fuzzy logic enables users of models, which are based on this technique, a parametrization similar to human reasoning. The simplicity of the fuzzy logic consists of the attribution of linguistic labels to the model input variables.This dissertation uses fuzzy logic techniques, such as ANFIS and limited rules, to identify the behavior of the dissolved oxigen in the aeration tank of a benchmark activated sludge wastewater treatment plant, with nitrogen removal. 


\section{ÍNDICE}

Capítulo 1. Introdução …............................................................................................9

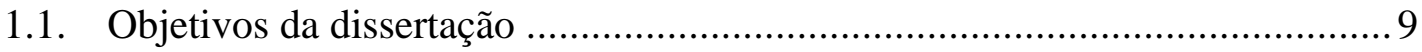

1.2. Motivação.........................................................................................

1.3. Estudo de referências bibliográficas sobre modelagem de processos de tratamento de esgotos por lodos ativados ............................................................ 12

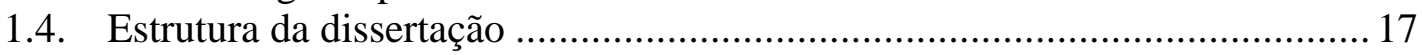

Capítulo 2. Descrição do Processo de Tratamento de Esgotos.................................. 19

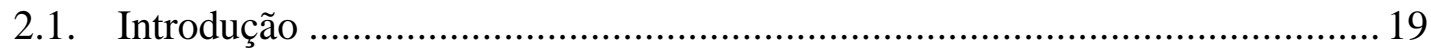

2.2. Descrição do processo de tratamento de esgotos por lodos ativados ..............20

2.2.1. Remoção de matéria carbonácea ………………………………….........2

2.2.2. Remoção biológica de nitrogênio ............................................................2 26

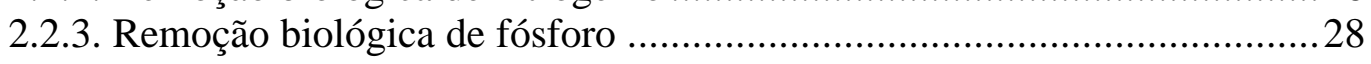

Capítulo 3. Identificação Nebulosa ............................................................................33

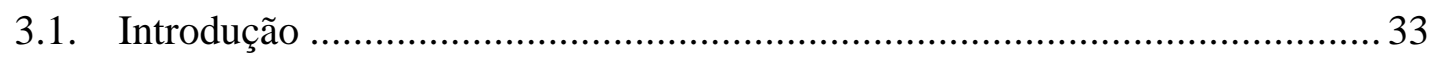

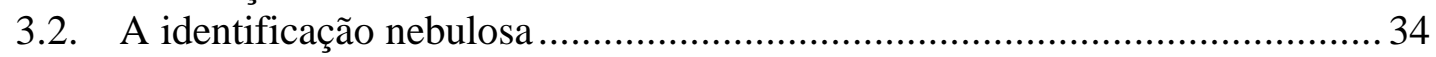

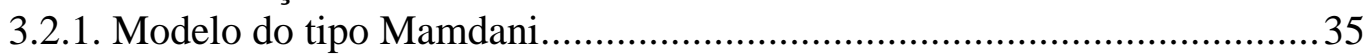

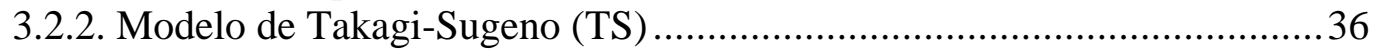

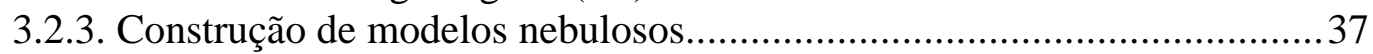

3.2.4. Modelagem neuro-nebulosa (neuro-fuzzy) .............................................. 40

3.2.5. Modelagem baseada em técnicas de discretização nebulosa .......................43

3.2.6. Modelagem baseada em técnicas de discretização nebulosa com número

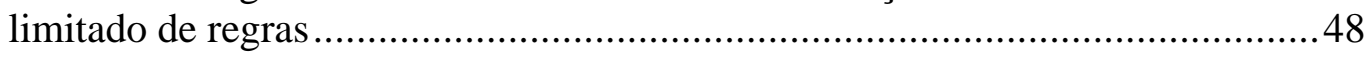

Capítulo 4. Desenvolvimento do Trabalho .......................................................50

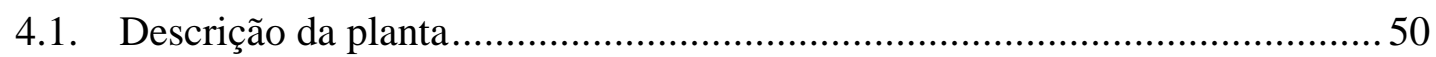

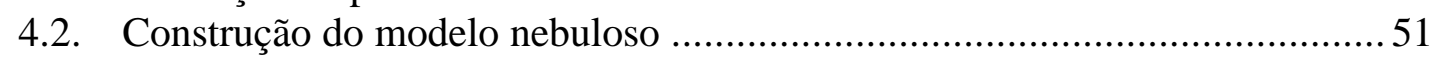

4.2.1. Escolha das variáveis de entrada ...........................................................51

4.2.2. Escolha do tempo de amostragem ...........................................................60

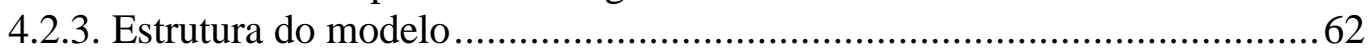

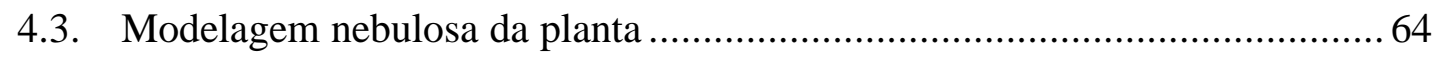

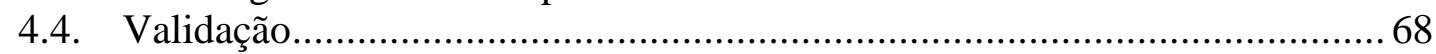

Capítulo 5. Conclusões e perspectivas de trabalhos futuros ...................................... 74

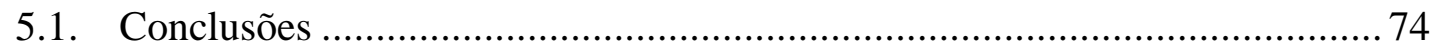

5.2. Perspectivas de trabalhos futuros .............................................................. 76 


\section{Lista de Figuras}

Figura 2.1. Planta Típica de uma ETE por Lodos Ativados .................................... 19

Figura 2.2. Sistema Contínuo de Lodos Ativados.................................................22

Figura 2.3. Processo de remoção biológica de fósforo .............................................. 30

Figura 3.1. Representação de obtenção de saída para modelo TS ............................. 36

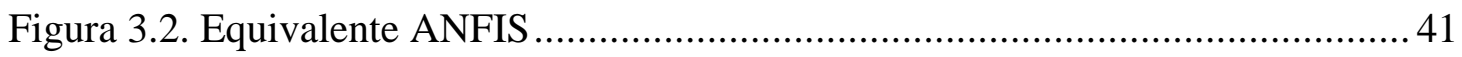

Figura 4.1. Configuração do benchmark ASWWTP-USP) ...................................... 50

Figura 4.2 Perturbação em degrau na concentração de amônia afluente..................... 52

Figura 4.3 Resposta do OD à perturbação em degrau na concentração de amônia

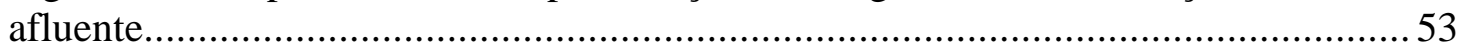

Figura 4.4 Perturbação em degrau na concentração afluente de $S_{\text {s }}$........................... 53

Figura 4.5 Resposta do OD à perturbação em degrau na concentração afluente de $S_{\mathrm{s}} 54$

Figura 4.6 Perturbação em degrau na vazão de ar na $2^{\mathrm{a}}$ zona aeróbia 54

Figura 4.7 Resposta do OD à perturbação em degrau na vazão de ar na $2^{\mathrm{a}}$ zona aeróbia.

Figura 4.8 Perturbação em degrau na vazão de recirculação de lodo

Figura 4.9 Resposta do OD à perturbação em degrau na vazão de recirculação de lodo 56

Figura 4.10 Perturbação em degrau na vazão de esgotos afluente. 56

Figura 4.11 Resposta do OD à perturbação em degrau na vazão de esgotos afluente. 57

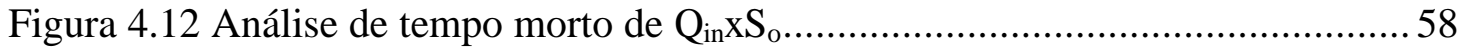

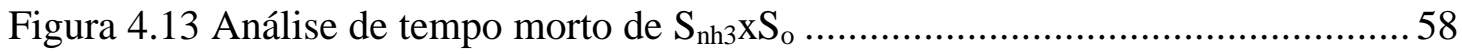

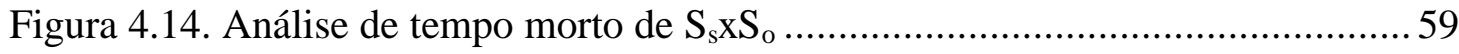

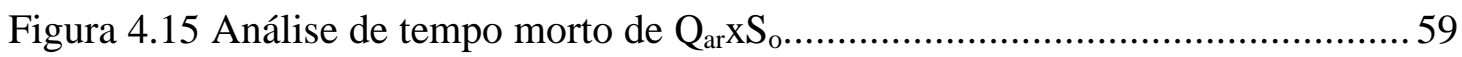




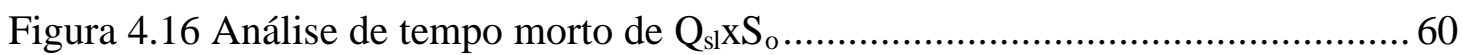

Figura 4.17 Análise de correlação linear ..............................................................61

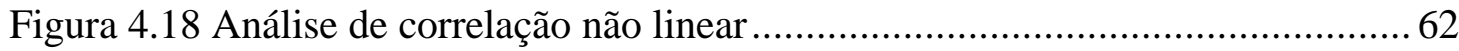

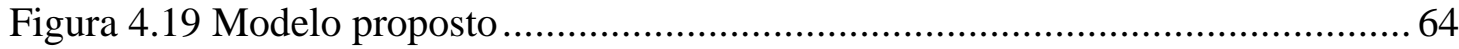

Figura 4.20 Sinal de entrada de vazão de esgotos afluente.......................................65

Figura 4.22 Sinal de entrada de DQO rapidamente biodegradável afluente................66

Figura 4.23 Sinal de entrada de vazão de ar na $2^{\text {a }}$. zona aeróbia ...............................66

Figura 4.24 Sinal de entrada de vazão de recirculação de lodo ..................................6 67

Figura 4.25 Diagrama de Validação do Modelo .......................................................6 68

Figura 4.26. Saída de Validação do Modelo para 1 Regressor por variável de entrada73

Figura 4.27. Comparativo da saída de validação dos modelos com o processo para 1

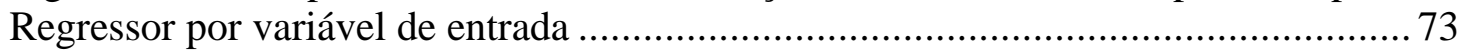




\section{Lista de Tabelas}

Tabela 4.1. Comparativo do ISE para 1 Regressor por Variável de Entrada...............69

Tabela 4.2. Comparativo do ISE para 2 Regressores por Variável de Entrada ...........69

Tabela 4.3. Comparativo do ISE para 3 Regressores por Variável de Entrada ...........69

Tabela 4.5. Comparativo do erro máximo para 1 Regressor por Variável de Entrada. 70

Tabela 4.6. Comparativo do erro máximo para 2 Regressores por Variável de Entrada70

Tabela 4.7. Comparativo do erro máximo para 3 Regressores por Variável de Entrada70

Tabela 4.8. Comparativo do erro máximo para 4 Regressores por Variável de Entrada71

Tabela 4.9. Parâmetros antecedentes para 1 Regressor por Variável de Entrada ........ 71

Tabela 4.10. Comparativo dos parâmetros conseqüentes para 1 Regressor por

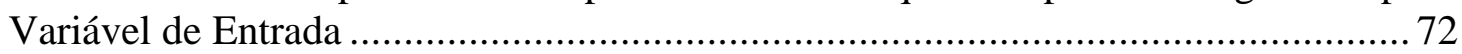

Tabela 4.11. Centros de clusters da técnica de regras limitadas para 1 Regressor por

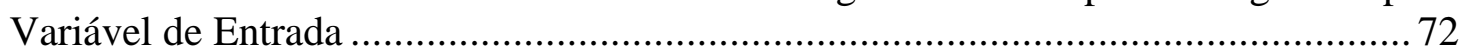




\section{Capítulo 1. Introdução}

\subsection{Objetivos da dissertação}

Nesse trabalho propõe-se o desenvolvimento de um modelo nebuloso que descreva o comportamento da concentração de oxigênio dissolvido (OD) no tanque de aeração de uma planta simulada de tratamento de esgotos. Esse modelo de referência (benchmark) é intitulado ASWWTP-USP (Sotomayor et al., 2001). A variável de processo OD foi escolhida para modelagem pelo impacto que seu controle tem no custo de consumo de energia elétrica de uma estação de tratamento de esgotos (Sampaio e Gonçalves, 1999) e pela sua importância no controle operacional deste processo (Van Haandel e Marais, 1999 e Von Sperling, 1997).

\subsection{Motivação}

A água é um recurso natural reconhecidamente essencial para a existência de vida na Terra: todo ser vivo do planeta é constituído em sua maior parte desse fluido. Os seres humanos passam seus primeiros nove meses de vida cercados por ele e seu corpo necessita de 2 a 3 litros diários dessa substância para a manutenção de uma vida saudável. Entretanto, apesar de mais de $70 \%$ da superfície deste planeta ser coberta de água, apenas uma pequena parte é própria para consumo humano ou utilização na agricultura (cerca de $0,3 \%$ ).

A influência do homem sobre os recursos hídricos que o cercam é muito grande. Em regiões densamente povoadas, como é o caso da Região Metropolitana de São Paulo (RMSP), o lançamento contínuo de cargas orgânicas e tóxicas em suas bacias hidrográficas tem provocado a degradação de seus recursos hídricos. Essa degradação apresenta o efeito de impulsionar a captação de água bruta para abastecimento público em regiões cada vez mais distantes, gerando conseqüentemente maiores investimentos para a garantia da universalização do 
serviço. Outra conseqüência desse fato é o aumento no aparecimento de doenças de veiculação hídrica que se torna um problema de saúde pública, seja pela elevação dos índices de mortalidade infantil ou pelos gastos incrementados no setor. Assim, os investimentos em coleta e tratamento de esgotos em países em desenvolvimento, como o Brasil, têm crescido progressivamente. As regiões mais populosas desses países, por todos os problemas de crescimento desordenado, demandam soluções e investimentos de grande escala para o saneamento ambiental. Por outro lado, a consciência ambiental crescente de suas sociedades acarreta uma legislação correspondente mais restritiva e uma cobrança de ações positivas por parte do Estado. Tais demandas, porém, esbarram na escassez de espaço físico e recursos financeiros para o tratamento de volumes de esgotos que só crescem com o passar dos anos. Essa busca de um equacionamento adequado da obtenção de efluentes com parâmetros de qualidade determinados, volumes crescentes e recursos escassos tem apontado para uma fundamental otimização das plantas de tratamento de esgotos existentes. Nesse sentido, a automação e, de modo intrínseco, o estabelecimento de estratégias de controle operacional, pode ser uma ferramenta valiosa para a melhoria de desempenho dessas plantas.

A automação da operação de estações de tratamento de esgotos, apesar de já acontecer desde o final dos anos 60 do século passado na Europa e nos Estados Unidos, pode ser considerada ainda muito incipiente. A monitoração e controle das plantas têm ocorrido em alguns processos unitários, visando a observação e controle de parâmetros determinados. Na década seguinte, algum avanço foi conseguido com a disseminação do controle de oxigênio dissolvido. Algumas razões podem ser citadas para esse lento avanço na automação de estações de tratamento de esgotos (Beck, 1986, Olsson, 1993 e Jeppsson, 1996):

- Entendimento: o processo de tratamento de esgotos é bastante complexo e não é trivial entendê-lo e otimizá-lo. Além disso, poucos engenheiros de controle têm dedicado pesquisas direcionadas a estações de tratamento de esgotos. 
- Instrumentação inadequada: a maior parte da instrumentação utilizada para monitoramento e controle das plantas ainda não é confiável e necessita de uma manutenção contínua.

- Motivos econômicos: há uma dificuldade por parte das empresas de saneamento ambiental em detectar o retorno econômico de investimentos vultosos em um sistema de controle mais avançado.

- Treinamento: ainda há uma ausência de treinamento adequado de operadores e engenheiros de processo para que tenham um entendimento básico de algoritmos e estratégias de controle a fim de perceberem o potencial do uso da automação.

Entretanto, o interesse pela utilização de formas de controle mais sofisticadas está crescendo. Para Lindberg (1997), as seguintes razões podem ser mencionadas:

- Com a tendência de um contínuo crescimento da vazão de esgotos a serem tratados pelas plantas existentes, o controle e a otimização podem ser ferramentas valiosas para que o tratamento dessas vazões ocorram nos mesmos volumes construídos.

- Exigências mais rígidas da qualidade dos efluentes.

- As multas relacionadas à qualidade dos efluentes lançados diretamente nos corpos receptores têm sido mais severas.

- Há uma consciência ambiental crescente por parte da sociedade, focada principalmente em questões como sustentabilidade e consumo de energia. 
- Alguns medidores e atuadores estão melhorando de qualidade devido a um contínuo desenvolvimento.

- Cada vez mais aparecem alternativas de processo de tratamento que são difíceis de controlar manualmente.

Portanto, a existência de modelos que reflitam o comportamento dinâmico de estações de tratamento de esgotos ou mesmo de alguns de seus processos unitários, se torna uma ferramenta valiosa para o entendimento do processo. Esse entendimento pode auxiliar no estabelecimento de estratégias de controle operacional de maior eficiência bem como no desenvolvimento de sistemas de suporte a decisão, simuladores para treinamento de operadores e de projetos novos, sensores virtuais ou mesmo otimizações de plantas. A utilização de métodos não-lineares de modelagem lingüística para a execução desse trabalho tem seu grande incentivo na possibilidade de utilizar o conhecimento empírico humano do operador na "parametrização" das regras de inferência. Nesse sentido, o caráter não linear do processo biológico de tratamento de esgotos bem como a grande interação entre os efeitos de suas variáveis são fatores adicionais para o estímulo da utilização da técnica de modelagem escolhida.

\subsection{Estudo de referências bibliográficas sobre modelagem de processos de tratamento de esgotos por lodos ativados}

Como já foi mencionado, plantas de tratamento de esgotos com desempenho operacional adequado têm sido uma importante ferramenta para a obtenção de resultados positivos tanto no que se refere ao saneamento ambiental como na área de saúde pública. 
Para que essas plantas obtenham um desempenho mínimo aceito pelos agentes de fiscalização responsáveis, é necessário que os operadores tenham um conhecimento do processo que basicamente se origina da experiência de campo. Assim, plantas de tratamento de esgotos por lodos ativados, que são extremamente mecanizadas, são operadas a contento tendo desempenhos operacionais diferenciados dependendo do grau de experiência de seu quadro de operadores. Nolasco e Helou (1998) observaram que um melhor entendimento de como o processo de tratamento se comporta permite a obtenção de um controle operacional mais apurado e uma conseqüente otimização da capacidade instalada. Por outro lado, Chan et al. (1987), Nolasco et al. (1994), Vanrolleghem et al. (1996) e Lant e Steffens (1998) ressaltaram que a otimização de estações de tratamento de esgotos é incentivada por uma necessidade de adiamento de investimentos de ampliação das plantas em operação decorrente da atratividade econômica negativa da prestação do serviço bem como da baixa disponibilidade de área livre nas grandes cidades para a construção de tais estações, além da busca de reduções de custos operacionais como energia elétrica. Nesse sentido, especialistas e concessionárias operadoras de saneamento ambiental por todo o mundo têm envidado esforços na busca da otimização de suas plantas de tratamento de esgotos, visando detectar "gargalos" de processo e assim maximizar os desempenhos funcionais de cada processo unitário, mantendo padrões de lançamento de efluentes dentro do que exige a respectiva legislação. Uma das possíveis estratégias de otimização é o desenvolvimento de automação dos processos unitários das plantas de tratamento de esgotos.

Como a automação de plantas de tratamento de esgotos exige investimentos relativamente elevados, seria interessante que ela fosse desenvolvida não apenas levando em consideração a experiência dos operadores mas também um melhor conhecimento do comportamento do processo. Daí a necessidade do desenvolvimento de simuladores baseados em modelos matemáticos bem construídos.

O benchmark desenvolvido por Sotomayor et al. (2001) modela uma planta de lodos ativados com pré-desnitrificação. Esse benchmark consiste em um simulador 
desenvolvido em plataforma MATLAB/Simulink v.5.3 (MathWorks, 1999) baseado no modelo fenomenológico de bioreator ASM1 da IAWPRC (Henze et al., 1987) e no modelo do decantador de múltiplas camadas proposto por Takács et al. (1991) para o decantador secundário.

Porém, Jeppsson (1993) considerou que os modelos matemáticos propostos pela IAWPRC são bastante complexos e inadequados para o projeto do controle, pois são compostos de treze equações diferenciais não lineares interrelacionadas que contém uma quantidade significativa de parâmetros razoavelmente desconhecidos e difíceis de se estimar on-line. Nesse sentido, Ketchen (1997) observou que muitos desses parâmetros são diretamente medidos enquanto outros assumem valores adotados na literatura. Além disso, Dunn et al.(1992) argumentaram que os parâmetros dessas equações variam com a composição e temperatura dos esgotos bem como com a biomassa heterotrófica presente, que geralmente não é mensurável.

Levando esses fatores em consideração, Lindberg (1997) utilizou dados operacionais de uma planta piloto construída na principal estação de tratamento de esgotos de Uppsala (Suécia) para a modelagem do comportamento de algumas variáveis importantes do processo, como concentração de nitrato, a função de transferência de oxigênio $\left(K_{L} a\right)$ e a taxa de respiração $(R(t))$ visando o estabelecimento de estratégias de controle mais eficientes. Para a modelagem da concentração de nitrato foi empregada uma estrutura ARX, onde as entradas adotadas foram vazão de etanol, a vazão mássica afluente de substrato solúvel e a vazão mássica recirculada de nitrato (considerando as duas vazões mássicas de recirculação: a interna e a de lodo recirculado). Para a modelagem da função de transferência de oxigênio $\left(K_{L} a\right)$ e da taxa de respiração $(R(t))$, foi utilizado um Filtro de Kalman tendo como variáveis de entrada a concentração de oxigênio dissolvido no tanque de aeração e a vazão de ar neste tanque.

Ghavipanjeh et al. (2001) desenvolveram identificação linear do comportamento da concentração de nitrato ao redor de um nível de regime permanente no compartimento de pré-desnitrificação, obtendo-se assim um modelo discreto 
reduzido de segunda ordem. Essa identificação visava estabelecer um controle PIP ("proportional-integral-plus") baseado em modelo para manutenção da concentração de nitrato da câmara anóxica de um benchmark em um valor determinado.

Sotomayor et al. (2000) utilizaram o Filtro de Kalman Extendido contínuo-discreto para a obtenção dos modelos das concentrações de nitrato e oxigênio dissolvido de um benchmark de planta com remoção de nitrogênio. Tal técnica se mostrou bastante adequada para a modelagem das variáveis deste processo.

Libelli e Giovannini (1997) desenvolveram um estimador discreto de tempo real da população microbiana bem como de sua respectiva taxa de crescimento específico. Para tal, utlizaram a concentração de nitrato, a taxa de diluição, a taxa de recirculação de lodo, a taxa de compactação do decantador secundário e o fator de crescimento dos microrganismos autotróficos como entradas do modelo.

Catunda et al. (1998) elaboraram um método alternativo para a medição da Taxa de Consumo de Oxigênio (TCO) a partir da modelagem da equação discreta da dinâmica da concentração de OD (através de regressão linear), obtendo vantagens comparativas ao método clássico de medida de tal variável do processo. Essa modelagem considerou como entradas as concentrações de OD no instante anterior e no afluente, a concentração de OD de saturação, a vazão de entrada do afluente, o coeficiente global de transferência de oxigênio e a vazão de ar inserido no sistema.

Aubrun et al. (2001) desenvolveram um sensor virtual (software sensor) de DQO do afluente a ser tratado utilizando um Filtro de Kalman de entrada desconhecida (UIFK) para um processo anaeróbio. As variações de DQO foram modeladas usando somente medidas on-line da vazão afluente, da vazão de gás metano produzido e o pH do efluente produzido pelas fases de metanogênese e acidogênese.

É importante ressaltar que além de testar diferentes estratégias operacionais e avaliar diferentes técnicas de controle e otimização de plantas de tratamento de esgotos, o desenvolvimento de simuladores e/ou modelos destas plantas de saneamento 
ambiental tem papel significativo no treinamento de seus operadores. Nesse sentido, diversos trabalhos têm aparecido na literatura. Entre eles: Jeppsson e Olsson (1993), Jeppsson (1996), Lindberg (1997), Hasselblad et al. (1998), Julien et al. (1998), Cheng e Ribarova (1999) e Queinnec e Dochain (2001). Analogamente, diversos pacotes de simulação de estações de tratamento de esgotos existem atualmente, tais como GPS-X, BIOWIN, AQUASIM, EFOR, STOAT, WEST e DSP.

A maior parte dos simuladores acima mencionados é elaborada utilizando modelos fenomenológicos da IAWPRC (principalmente o modelo $\mathrm{n}^{\circ} 1$ ), o que torna suas respectivas parametrizações significativamente complexas, visto que nem todos os parâmetros são conhecidos pelos operadores (por exemplo, taxas de crescimento dos microrganismos e frações do substrato). Assim, dependendo da composição do esgoto afluente à estação e de fatores particulares à sua biota, poderá haver variação significativa dos parâmetros cinéticos envolvidos.

Jeppsson (1996) acentua que o uso de técnicas de identificação lineares paramétricas tem sua eficácia comprometida pelo caráter acentuadamente não linear dos processos biológicos de tratamento de esgotos e pela ausência de significado físico dos parâmetros identificados nos modelos matemáticos.

Desse modo, o que se observa na respectiva literatura é que grande parte das abordagens de modelagem de estações de tratamento de esgotos derivam de duas vertentes: os modelos fenomenológicos baseados na cinética do processo (Henze et al., 1987), como o modelo $\mathrm{n}^{\circ} 1$ da IAWPRC, e modelos baseados nas relações de entrada-saída (Carvalho et al., 1999 e Sotomayor et al., 2000).

O que se propõe nesse trabalho é o estudo de uma estrutura de modelagem de processos que tem merecido recentemente estudos mais aprofundados: a utilização de técnicas baseadas em regras. Tais técnicas se utilizam do conhecimento prático do operador sobre o referido processo, dessa maneira baseando a modelagem em variáveis lingüísticas o que torna mais próximo do operador o modelo construído. Nesse sentido, as variáveis lingüísticas do processo de modelagem e/ou de controle 
baseado em regras têm muito mais significado para o operador do que os parâmetros cinéticos dos modelos fenomenológicos já mencionados.

\subsection{Estrutura da dissertação}

Nesta seção é apresentada a estrutura da dissertação. A dissertação é composta de 5 capítulos que são descritos a seguir:

Capítulo 1- Introdução. Este capítulo trata do objetivo e motivações que levaram ao desenvolvimento do trabalho. As motivações são complementadas por uma revisão bibliográfica acerca das abordagens que estão sendo empregadas para a modelagem dos processos de tratamento de esgotos.

Capítulo 2- Descrição do processo de tratamento de esgotos. Neste capítulo, é apresentada uma descrição do processo de tratamento de esgotos por lodos ativados, destacando a seqüência física de uma planta, os conceitos de remoção biológica de matéria carbonácea, bem como a remoção de nutrientes (nitrogênio e fósforo).

Capítulo 3- Identificação nebulosa. Neste capítulo são abordados os modos mais comuns de modelagem nebulosa (Mamdani e Takagi-Sugeno) e os passos necessários para a construção de modelos nebulosos. Nesta seção, também é realizada uma descrição de métodos de modelagem nebulosa derivadas do método de Takagi-Sugeno que serão utilizados nesta dissertação (ANFIS e técnica de discretização nebulosa).

Capítulo 4- Desenvolvimento do trabalho. Este capítulo trata do projeto de um modelo nebuloso do comportamento da concentração de oxigênio dissolvido do tanque de aeração do benchmark ASWWTP-USP. É feita uma comparação da utilização de modelagem neuro-nebulosa, pelo uso da ferramenta ANFIS do toolbox fuzzy da plataforma Matlab, com a modelagem através do uso de técnica de discretização nebulosa. 
Capítulo 5- Conclusões. Neste capítulo, são apresentadas considerações a respeito dos resultados obtidos com as duas técnicas de modelagem nebulosa, através da observação de gráficos da variável de saída do modelo bem como a estrutura final proposta com seus parâmetros otimizados 


\section{Capítulo 2. \\ Descrição do Processo de Tratamento de Esgotos}

\subsection{Introdução}

Os esgotos têm seu processamento em etapas físicas, biológicas e químicas ao passarem por uma estação de tratamento, antes de serem lançados no corpo receptor. Um diagrama de uma planta típica é mostrado na figura 2.1:

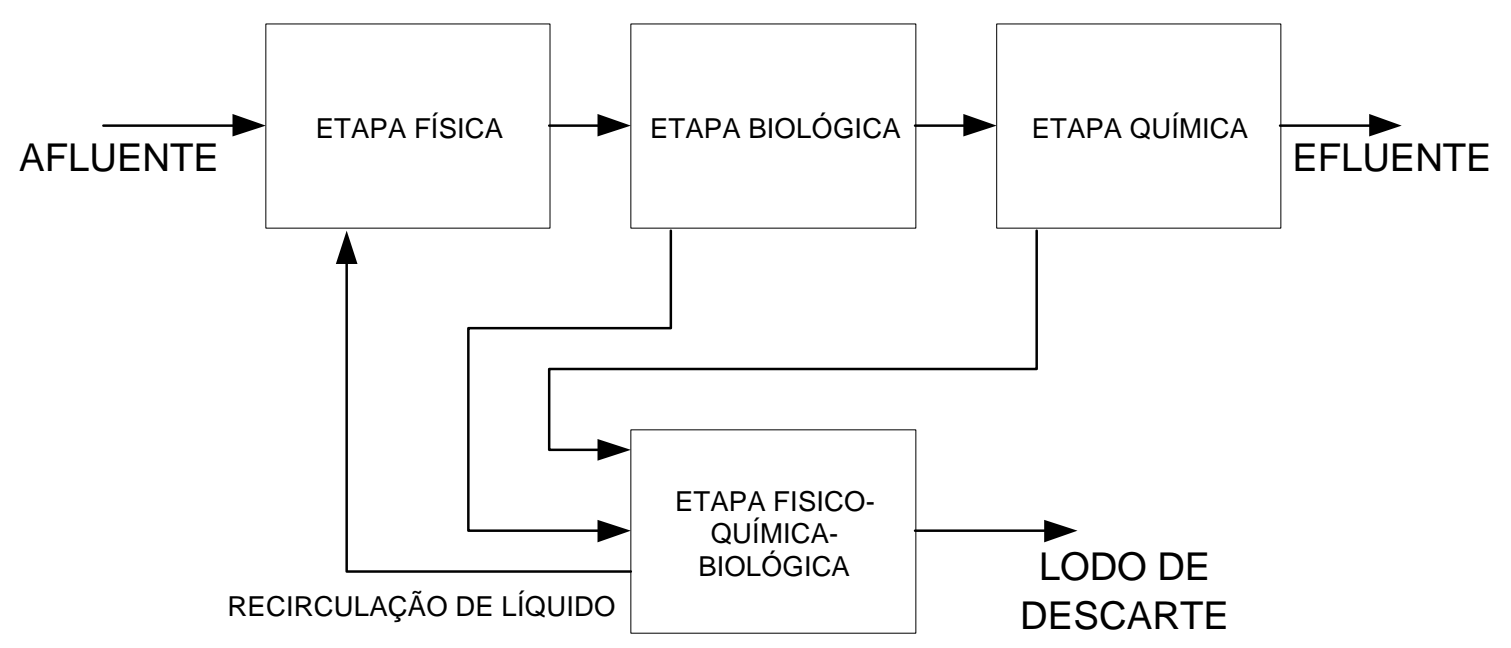

Figura 2.1. Planta Típica de uma ETE por Lodos Ativados

A etapa física é responsável pela remoção de parte dos sólidos sedimentáveis, o que possibilita unidades de processo subseqüentes de menores dimensões.

A etapa biológica remove a matéria orgânica e, quando assim projetada, também os nutrientes. Nessa unidade de processo ainda ocorre a separação sólido-líquido através de decantação. 
Dependendo de como será utilizada a água do corpo receptor onde os efluentes serão lançados, pode-se acrescentar após a etapa biológica uma unidade de processamento químico para desinfecção, visando a eliminação de organismos patogênicos, possibilitando o reuso por parte do homem.

O processo de tratamento de esgotos também necessita de uma etapa física-químicabiológica de tratamento do lodo descartado (rejeito do tratamento). Esse lodo deve ser estabilizado, ou seja, deve ter sua matéria orgânica removida, e ter seu volume reduzido de maneira que possa ser disposto ou utilizado em local adequado.

\subsection{Descrição do processo de tratamento de esgotos por lodos ativados}

As primeiras formas de tratamento de águas residuárias, que datam do final do século XVIII, tinham como foco principal a remoção de sólidos sedimentáveis através de simples decantação, sendo o exemplo mais conhecido o tanque Imhoff. Essas formas de tratamento só podiam depurar parcialmente os esgotos, devido à baixa sedimentabilidade de grande parte do material orgânico encontrado nas águas residuárias.

O processo de tratamento de esgotos por lodos ativados foi introduzido nas primeiras décadas do início do século passado, tendo como característica principal uma remoção mais completa de matéria orgânica através de processos biológicos. Nesta época, foi observado que havia remoção de matéria orgânica em águas residuárias quando estas últimas eram aeradas e que, ao mesmo tempo, se formavam flocos macroscópicos de microorganismos cuja separação da fase líquida podia ser realizada por decantação simples, obtendo-se desse modo um lodo biológico. Entretanto, a constatação valiosa de foi que esse lodo ao ser adicionado a outra batelada de esgotos, ocasionava um incrível aumento de eficiência de remoção de 
material orgânico e um crescimento adicional de lodo. Assim, o termo "lodo ativado" se deve a essa capacidade do lodo biológico acelerar a remoção do material orgânico.

Nos início dos experimentos com tratamento de águas residuárias, o processo de tratamento por lodos ativados ocorria em regime de bateladas. Os esgotos eram introduzidos em um reator biológico que continha o lodo ativado e depois que o reator estivesse cheio, era feita a aeração do conteúdo, removendo assim o material orgânico. A aeração, então, era desligada e, através de decantação acontecia a separação sólido-líquido. Um novo ciclo de tratamento ocorria após a descarga do efluente tratado.

Desde sua descoberta até os dias de hoje, o processo de lodos ativados não sofreu mudança quanto ao seu princípio: a obtenção de remoção de matéria orgânica dos esgotos através de um contato permanente com o lodo ativado conjugado a uma aeração da mistura. Entretanto, no decorrer dos anos que se seguiram à descoberta do sistema de lodos ativados, muitas contribuições importantes melhoraram o desempenho do sistema.

Um avanço inicial no desenvolvimento do sistema de lodo ativado foi a inclusão de um decantador de lodo à jusante do reator biológico, criando uma alternativa contínua desse processo de tratamento de esgotos. A figura 2.2 representa um sistema contínuo de lodo ativado. 


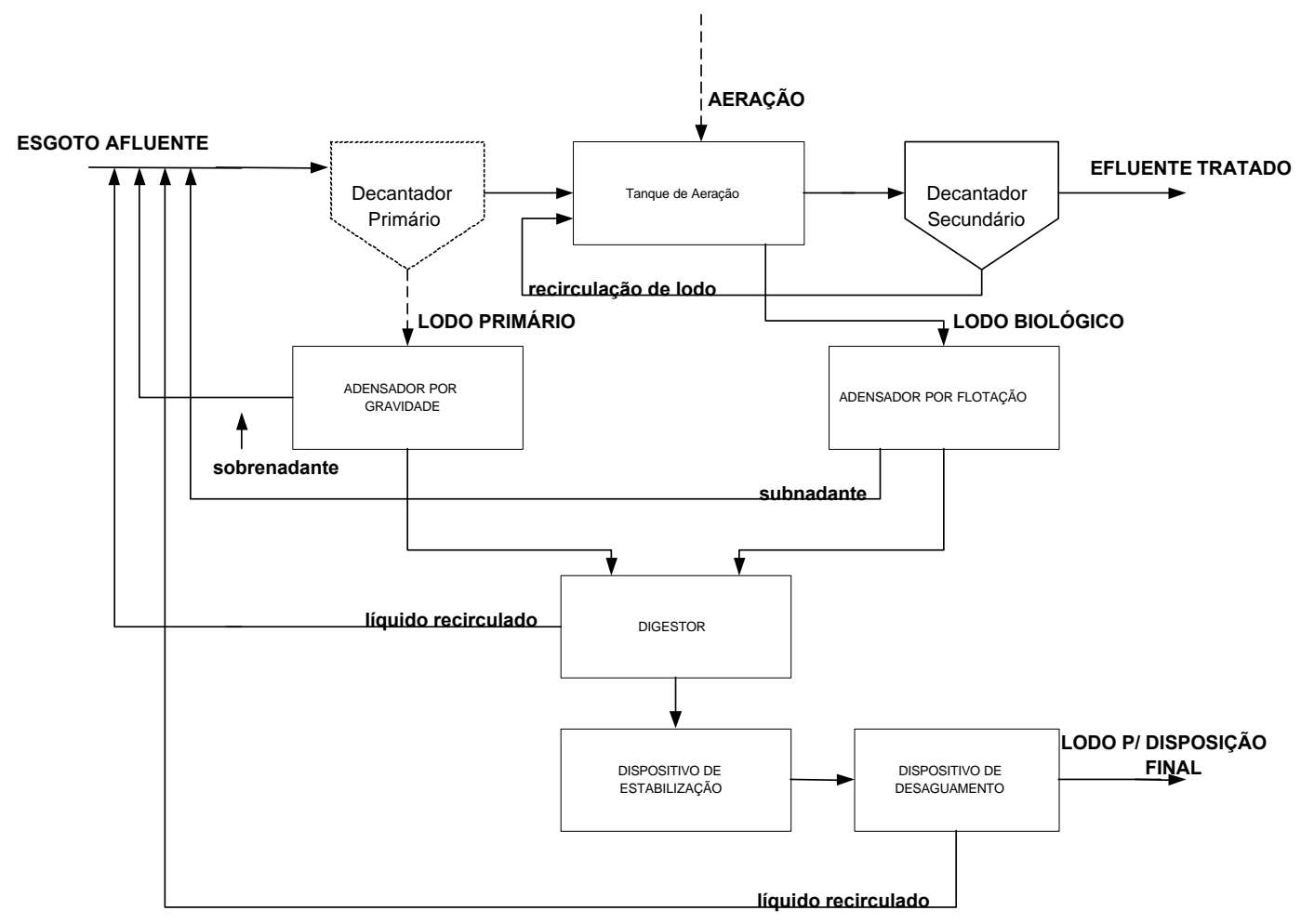

Figura 2.2. Sistema Contínuo de Lodos Ativados

O esgoto afluente à estação de tratamento passa por um decantador primário (opcional) para remoção de cerca de $30 \%$ da matéria orgânica, o que implica em reatores biológicos com volumes menores e uma redução significativa da potência dos dispositivos de aeração instalados. Nos reatores biológicos, a matéria carbonácea é oxidada pelos microorganismos mantidos em suspensão pelo sistema de aeração, formando o que é freqüentemente denominado licor misto. A ininterrupta entrada de esgotos no reator biológico provoca uma descarga contínua do licor misto para o decantador secundário, onde há uma separação sólido (lodo)- líquido (efluente). $\mathrm{O}$ efluente é descarregado em um corpo d'água receptor, enquanto uma parte do lodo produzido é recirculado para o reator biológico, sendo chamado de lodo de retorno.

Na figura 2.2 pode-se ainda verificar que há uma fase do processo de tratamento que se ocupa do lodo de excesso que é gerado. Esse lodo ativado de excesso é descarregado do reator biológico para que não haja um crescimento contínuo de lodo no sistema, o que acarretaria um aumento da sua concentração. Deve-se manter a 
concentração de lodo de uma maneira que não exceda um valor máximo, não comprometendo desse modo a função de separador de fases do decantador secundário. Para que essa importante função do decantador secundário tenha o desempenho esperado, ao se atingir um valor de concentração máxima haverá descarga de lodo para que a massa e a concentração de lodo permaneçam constantes. Para que isso ocorra, faz-se que a descarga seja igual à produção de lodo. Portanto, esse rejeito (o lodo) deve ter tratamento adequado de modo que fique nas condições exigidas pela legislação para disposição final. Uma primeira etapa de adensamento desse lodo é realizada com o objetivo de uma redução inicial de seu volume, reduzindo os volumes necessários para os processos unitários subseqüentes. O lodo adensado ainda possui uma fração significativa de material orgânico biodegradável que deverá ser reduzida em um digestor através de um processo de estabilização. A estabilização de material orgânico biodegradável do lodo tem o objetivo de impedir sua putrefação. Esse estágio de tratamento é seguido por um processo unitário que é responsável pela remoção de grande parte da umidade do lodo (desaguamento), obtendo-se um lodo com um teor de sólidos consideravelmente maior, possibilitando sua utilização na agricultura, reflorestamento e outras formas de disposição permitidas.

Um processo adicional foi introduzido na década de cinqüenta que complementava aquele referente à remoção de matéria carbonácea: a nitrificação, que visava uma redução da demanda de oxigênio dos efluentes que continham amônia.

No entanto, na década de sessenta ainda do último século, houve a percepção que a remoção de matéria carbonácea não era suficiente para que os efluentes tratados lançados nos corpos d'água receptores não causassem nesses últimos sérios desequilíbrios ambientais. Constatou-se que a descarga de efluentes ainda ricos em nutrientes, principalmente nitrogênio e fósforo, estimulava o crescimento exacerbado de algas em lagos, lagoas e represas, provocando um fenômeno que é denominado eutrofização. Assim, desenvolveu-se um tratamento terciário que engloba aqueles já descritos, acrescido ainda de uma remoção de nutrientes (nitrogênio e fósforo). 
A remoção biológica de nitrogênio ocorre através de processos seqüenciais de nitrificação e desnitrificação. Na nitrificação há a oxidação biológica da amônia para nitrato utilizando-se oxigênio como oxidante enquanto a desnitrificação se desenvolve pela redução biológica de nitrato para nitrogênio molecular utilizando-se material orgânico como redutor.

Em países tropicais como o Brasil, apesar da maior parte das estações de tratamento de lodos ativados existentes não terem sido projetadas para que houvesse nitrificação, esse fenômeno ocorre porque as elevadas temperaturas aumentam a taxa de crescimento das bactérias nitrificadoras. Essa nitrificação não planejada acarreta uma deterioração da qualidade dos efluentes devido à desnitrificação inevitável no ambiente anóxico do decantador secundário. A desnitrificação ocasiona a liberação de nitrogênio molecular, que em seu movimento de ascensão se agrega aos flocos de lodo em sedimentação de alta concentração de material orgânico biodegradável, fazendo com que eles flotem e sejam descarregados juntamente com o efluente final, degradando sua qualidade. Esse fenômeno também provoca uma redução da massa de lodo presente no sistema, tornando-a insuficiente para a degradação do material orgânico afluente (Van Haandel e Marais, 1999).

É importante salientar que um parâmetro de controle operacional importante para determinar o tipo de material orgânico removido pelas plantas de lodos ativados (carbonáceo e/ou nitrogenado) é a idade do lodo. A idade do lodo é o tempo que uma célula bacteriana permanece no tratamento. Em sistemas de lodos ativados, por haver recirculação de lodo para a entrada do bioreator, a idade do lodo é maior que o tempo de detenção hidráulica do esgoto neste mesmo bioreator. A quantidade do lodo a ser recirculado depende fundamentalmente da qualidade do lodo sedimentado no decantador secundário: quanto maior a concentração desse lodo, menor poderá ser a vazão de recirculação, para que seja mantida uma determinada concentração de sólidos no reator. Uma idade do lodo de 4 a 10 dias caracteriza uma planta como sendo convencional (remoção somente de matéria carbonácea), ao passo que uma idade do lodo igual ou superior a 10 dias classifica uma planta como de aeração prolongada. 


\subsubsection{Remoção de matéria carbonácea}

A base para o entendimento dos fundamentos da remoção de matéria carbonácea em processos de tratamento de esgotos reside no fato de que um alimento afluente (substrato) é fornecido a microrganismos que o metabolizam, isto é, incorporam parte do material biodegradável, enquanto o que resta é oxidado.

A concentração de substrato pode ser quantificada utilizando-se uma medida representada pelo teste da demanda química de oxigênio (DQO), onde uma amostra do esgoto afluente é misturada a uma substância consideravelmente ácida juntamente com outra catalizadora (sulfato de prata) sob uma temperatura de ebulição, fazendose assim que praticamente toda a matéria orgânica seja oxidada (Van Haandel e Marais, 1999). O resultado final (depois de cerca de duas horas) será quantificado como uma concentração de oxigênio consumida durante a reação (Standard Methods, 1997).

A biomassa é representada em termos de sólidos em suspensão (SS) (Von Sperling, 1997), pois a composição da biomassa se caracteriza pela presença de sólidos suspensos no reator (no caso de crescimento disperso). Entretanto, a conversão de substrato orgânico ocorre somente devido a uma fração orgânica dos sólidos suspensos presentes no reator, que é freqüentemente expressa em termos de sólidos suspensos voláteis (SSV). A fração inorgânica da biomassa não desempenha funções de tratamento biológico.

As bactérias heterotróficas oxidam o material orgânico transformando em gás carbônico mais água, utilizando OD para tal. Isso ocorre se for mantido um fator de carga alimento/microrganismos $(\mathrm{A} / \mathrm{M})$ adequado para as condições do bioreator. Quando a concentração de substrato (alimento) for elevada, tem-se um fator de carga elevado, ocasionando uma pobre eficiência em sua remoção. Se houver uma redução adequada do fator de carga, haverá uma eficiência na remoção de matéria carbonácea. Porém, se esse fator de carga for muito reduzido devido à muito baixa 
concentração de substrato, prevalecerá o mecanismo de respiração endógena característico de sistemas de aeração prolongada.

\subsubsection{Remoção biológica de nitrogênio}

O processo de remoção de nitrogênio de esgotos se fundamenta em dois subprocessos: a nitrificação e a desnitrificação.

\subsubsection{Nitrificação}

A nitrificação ocorre nas zonas aeradas do bioreator. Ela acontece por meio das bactérias nitrificadoras que utilizam oxigênio para transformar nitrogênio amoniacal primeiramente para nitrito e posteriormente a nitrato. É importante considerar que as bactérias nitrificadoras têm taxa de crescimento mais lenta que as que removem matéria carbonácea, necessitando portanto permanecerem mais tempo no bioreator para que possam remover o nitrogênio amoniacal. Dessa forma, a idade do lodo de plantas dimensionadas para que haja remoção de nitrogênio deverá ser mais elevada. Outros fatores, porém, influem na nitrificação. A temperatura acelera a taxa de crescimento das bactérias nitrificantes, fazendo por exemplo que a idade do lodo da planta para que ocorra nitrificação seja reduzida. $\mathrm{O}$ pH, segundo Von Sperling (1997), para que a taxa de nitrificação seja ótima e aproximadamente constante fica na faixa de 7,2 a 8,0. Abaixo de 7,2, a taxa de crescimento máxima das bactérias nitrificadoras decresce. A concentração de OD também influi diretamente no desempenho da nitrificação, pois se estiver abaixo de $0,2 \mathrm{mg} / \mathrm{L}$, esta última não se processa. Substâncias tóxicas podem também inibir seriamente o crescimento de bactérias nitrificantes que são mais sensíveis. 


\subsubsection{Desnitrificação}

A desnitrificação é o sub-processo da remoção de nitrogênio de esgotos que reduz nitratos a nitrogênio gasoso. A desnitrificação deve ser precedida da nitrificação, sendo seus microrganismos hetrotróficos do tipo facultativo. A desnitrificação provoca economia de oxigênio, pois ele é liberado pela redução dos nitratos, se tornando rapidamente disponível para a oxidação biológica da própria matéria orgânica (teoricamente economia de 62,5\% no consumo de OD). Outra economia significativa caso ocorra a desnitrificação é a de alcalinidade (por volta de 50\%).

Segundo Van Haandel e Marais (1999), as condições necessárias para a desnitrificação podem ser resumidas a seguir:

- Presença de uma massa bacteriana facultativa:

Uma bactéria é considerada facultativa quando pode utilizar tanto OD como nitrato para oxidação de material orgânico.

- Presença de nitrato e ausência de OD no licor misto:

Teores de OD no licor misto acima de 0,2 e $0,5 \mathrm{mg} / \mathrm{L}$ reduz substancialmente a taxa de desnitrificação.

- Condições adequadas para o desenvolvimento de microrganismos:

Podem ser destacados a temperatura, o pH e as substâncias tóxicas ou inibidoras. A temperatura tem efeito direto na taxa de crescimento das respectivas bactérias. $\mathrm{O} \mathrm{pH}$ ótimo para que a desnitrificação ocorra está na faixa de 6,5 a 7,5, com uma queda de $70 \%$ na taxa de desnitrificação para um pH de 6,0 e de 8,0. A desnitrificação ocorre após a nitrificação. Como as bactérias nitrificadoras são muito sensíveis a substâncias tóxicas, então a presença de tais substâncias nos esgotos pode reduzir significativamente também a desnitrificação. 
- Presença de um doador de elétrons (redutor de nitrato):

É essencial para a redução de nitrato. O doador de elétrons na desnitrificação é o material orgânico biodegradável. A alimentação deste doador de elétrons pode ser externa ou interna.

\subsubsection{Remoção biológica de fósforo}

\subsubsection{Introdução}

Van Haandel e Marais (1999) destacam que a remoção de nitrogênio não garante a inibição total do processo de eutrofização. Para que tal inibição ocorra, há a necessidade de uma remoção significativa de fósforo, visto que a limitação de lançamento de amônia nos corpos receptores não impede que determinados microorganismos sintetizem esta substância a partir de nitrogênio molecular.

O fósforo está presente nos esgotos em forma de fosfato. O fosfato, por sua vez, apresenta-se como fósforo inorgânico (ortofosfato e polifosfato) e o fósforo orgânico.

Segundo Von Sperling (1997), a caracterização das águas residuárias quanto às fontes e às quantidades de fósforo depende de alguns fatores, como uma fração significativa de despejos industriais, cargas não pontuais e pelos detergentes.

\subsubsection{Processo de remoção biológica de fósforo}

A explicação principal para o processo de remoção biológica de nitrogênio reside no efeito de estresse bacteriano provocado por uma zona aeróbia, o que acarreta a liberação de fósforo nesta zona do bioreator. Em zona subseqüente, o fósforo presente no líquido é assimilado em concentrações elevadas, o que proporciona uma remoção de fósforo através da remoção do lodo excedente. O lodo excedente removido possui teores deste macronutriente mais concentrado que plantas de 
tratamento que só removem matéria carbonácea. Van Haandel e Marais (1999) consideram que o processo de tratamento que remove fósforo faça com que o lodo excedente possua uma fração deste elemento de cerca de $38 \%$ contra $2,5 \%$ em outros processos de tratamento.

Os aspectos fundamentais para a remoção biológica de fósforo são os seguintes:

- a capacidade de determinados tipo de bactérias de armazenar quantidades significativas de fósforo na forma de polifosfatos. Estes microrganismos são denominados de Organismos Acumuladores de Fosfato (OAP).

- Estes microrganismos removem substratos simples de fermentação produzidos na zona aeróbia e os assimilam como produtos armazenados dentro de suas células.

- A energia produzida pela oxidação destes produtos armazenados é obtida na zona aeróbia. Nessa mesma zona, também há o aumento do armazenamento de polifosfatos na célula.

A zona anaeróbia é considerada um seletor biológico de microrganismos OAP, pois cria um ambiente propício para a assimilação de substrato por parte destes microrganismos antes daqueles não armazenadores de fósforo. Isto permite o desenvolvimento de uma grande quantidade de OAPs no sistema. O processo de remoção biológica de fósforo pode ser observado na figura 2.3. 


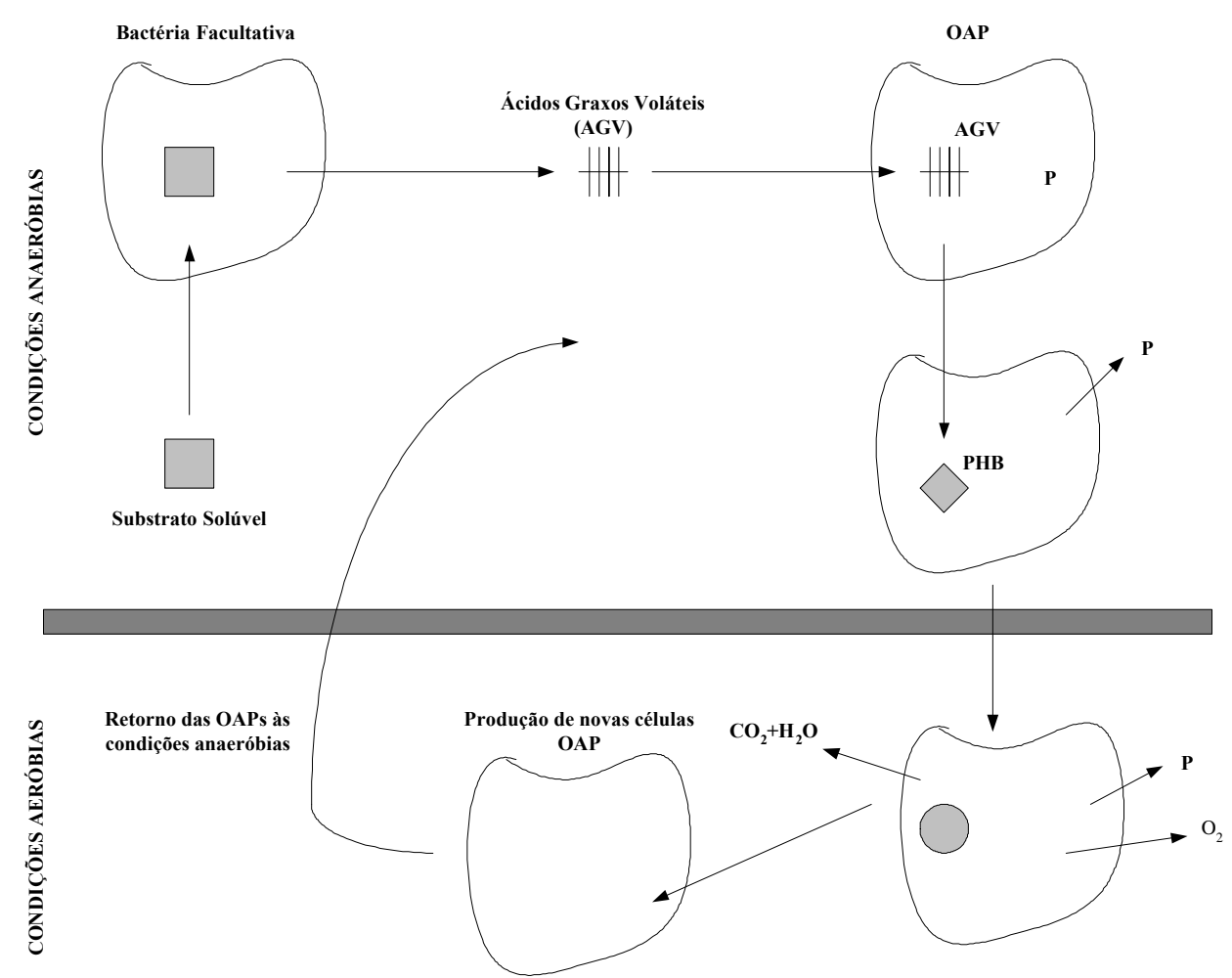

Figura 2.3. Processo de remoção biológica de fósforo (fonte: Von Sperling, 1997)

Os OAPs necessitam de alternância entre condições anaeróbias e aeróbias para que os mecanismos internos de armazenamento de energia sejam criados bem como moléculas orgânicas e polifosfatos.

Os organismos facultativos normalmente presentes nos esgotos e na zona anaeróbia convertem uma fração do substrato facilmente biodegradável a moléculas orgânicas de baixo peso molecular, como ácidos graxos voláteis que passam a se encontrar disponíveis no meio líquido. Os ácidos graxos voláteis são então rapidamente assimilados e acumulados dentro das células pelos OAPs. Estes microrganismos assimilam melhor estes produtos da fermentação do que outros normalmente presentes no processo, ocorrendo dessa forma uma seleção destes OAPs na zona anaeróbia. Os microrganismos liberam o fosfato previamente acumulado na etapa aeróbia, fornecendo energia para transporte do substrato e para a formação e armazenamento de produtos metabólicos orgânicos, como PHB (polihidroxibutirato). 
Nas condições aeróbias, o PHB é oxidado a gás carbônico e água. Os OAPs, então, armazenam em suas células o fosfato solúvel retirado da solução para geração de energia na etapa anaeróbia.

Assim, o fósforo que foi incorporado em grandes quantidades nas células de OAPs é removido juntamente com a remoção do lodo biológico excedente.

\subsubsection{Alguns fatores influentes na remoção biológica de fósforo}

Entre os fatores que mais influenciam o processo de remoção de fósforo no tratamento de águas residuárias estão:

a- Oxigênio dissolvido

A zona anaeróbia, como o próprio nome diz, não deve ter oxigênio dissolvido. A não satisfação dessa condição pode reduzir o desempenho da remoção de fósforo, visto que este processo depende da alternância entre condições anaeróbias e aeróbias. A literatura correlata menciona que a zona aeróbia deve manter uma concentração de OD entre 1,5 e 3,0 mg/L. Concentrações de OD abaixo dessa faixa podem ocasionar uma pobre redução de fósforo e uma nitrificação limitada, podendo ainda ocorrer o desenvolvimento de um lodo de má sedimentabilidade, deteriorando assim a qualidade do efluente por perda de sólidos. O excesso de concentração de OD compromete o desempenho do processo de desnitrificação com a presença de OD na primeira zona anóxica. Como conseqüência disso, poderá haver uma substancial elevação na concentração de nitratos, afetando a liberação de fósforo na zona anaeróbia.

\section{b- Temperatura}

Há indicações que para baixas temperaturas a taxa de liberação de fósforo seja menor, implicando na necessidade de maiores tempos de detenção na zona anaeróbia para que haja a conclusão da fermentação e um consumo suficiente de substrato. 
$\mathrm{c}-\mathrm{pH}$

Von Sperling (1997) sugere a seguinte correlação entre a variação de pH e a remoção de fósforo:

- a remoção de fósforo é mais eficiente com um pH entre 7,5 e 8,0.

- A remoção de fósforo tem seu desempenho bastante reduzido para valores de $\mathrm{pH}$ inferiores a 6,5, e o referido processo é totalmente perdido para um $\mathrm{pH}$ próximo a 5,0 .

d- Nitrato na zona anaeróbia

A redução de nitratos na zona anaeróbia utiliza os substratos para tal, reduzindo dessa maneira sua disponibilidade para assimilação pelos OAPs.

e- Idade do lodo

O estabelecimento da idade do lodo é um fator importante para o desempenho do processo de remoção de fósforo em plantas de tratamento de esgotos por lodos ativados, visto que o fósforo removido fica praticamente todo agregado ao lodo excedente que é retirado do sistema. Plantas com idade do lodo muito altas produzem pouco lodo excedente e, dessa forma, menor será a retirada de fósforo do sistema. Assim, sistemas de aeração prolongada não são indicados para plantas com remoção de fósforo. 


\section{Capítulo 3. \\ Identificação Nebulosa}

\subsection{Introdução}

A teoria convencional de sistemas se baseia em modelos matemáticos "crisp", tais como equações algébricas, diferenciais ou de diferenças. Para alguns sistemas, como por exemplo sistemas eletromecânicos, podem ser obtidos modelos matemáticos. Isso acontece porque as leis físicas que governam a dinâmica do processo são bem entendidas. Entretanto, para grande número de problemas práticos, é difícil a obtenção de um grau aceitável de conhecimento necessário para a modelagem física, sendo essa tarefa cara e demorada. Tais sistemas podem ser achados nas indústrias químicas e alimentícias, na biotecnologia, ecologia, finanças, sociologia, entre outras áreas. Uma parcela significativa sobre esses sistemas somente pode ser obtida pelo conhecimento de especialistas, operadores e projetistas do processo. Esse conhecimento, na maioria das vezes, pode ser vago e incerto para ser expresso por funções matemáticas. Entretanto, freqüentemente é possível descrever o funcionamento de sistemas por meio de linguagem natural, na forma de regras seentão.

A computação numérica precisa com modelos matemáticos somente faz sentido quando os parâmetros e os dados de entrada são bem conhecidos. Como isso não acontece com frequiência, é necessária uma estrutura de modelagem que possa processar de maneira adequada não só os dados obtidos, mas também a incerteza associada. A abordagem estocástica é uma maneira tradicional de tratar a incerteza. Entretanto, é entendido que nem todos tipos de incerteza podem ser tratados através de uma estrutura estocástica. Têm sido propostas várias alternativas, a lógica nebulosa é uma delas.

A identificação de sistemas dinâmicos do tipo entrada-saída tem uma grande aplicação prática no campo da pesquisa científica. Muitos sistemas reais são 
inerentemente não lineares e não podem ser representados por modelos lineares usados na identificação convencional de sistemas (Ljung, 1987). Recentemente, há uma forte concentração de estudos para o desenvolvimento de métodos de identificação de sistemas não lineares a partir de dados medidos. As redes neuronais artificiais e a lógica nebulosa pertencem às estruturas de modelo mais populares. Do ponto de vista da relação entrada-saída, os sistemas nebulosos são funções matemáticas flexíveis que podem aproximar outras funções ou simplesmente dados (medidas) com uma precisão desejada. Comparada com outras técnicas de aproximação bem conhecidas tais como redes neuronais artificiais, os sistemas nebulosos proporcionam uma representação mais transparente do sistema sob estudo, que se deve principalmente à possibilidade de interpretação lingüística na forma de regras. A estrutura lógica das regras facilita o entendimento e a análise do modelo de uma forma semi-qualitativa, próxima à maneira que os seres humanos pensam o mundo real (Babuska, 2001).

\subsection{A identificação nebulosa}

A identificação nebulosa é, para Shaw e Simões (1999), o estabelecimento de uma estrutura e de parâmetros de um modelo nebuloso, de tal maneira que o modelo tenha um comportamento próximo àquele do processo real. Essa operação acarreta na obtenção de um conjunto de regras (implicações nebulosas) e a geração de funções de pertinência. Isso pode ser conseguido por intermédio de obtenção de informações do especialista ou automaticamente por meio do método de equações relacionais.

Em sistemas baseados em regras, as relações entre as variáveis são representadas por intermédio de regras nebulosas se-então seguindo a forma geral:

Se proposição antecedente então proposição conseqüente.

A proposição antecedente é sempre uma proposição nebulosa do tipo x é A, onde x é uma variável lingüística e A é um termo lingüístico. Existirá um grau de pertinência (valor entre zero e um) para associar o quanto a variável $\mathrm{x}$ pertence ao termo 
lingüístico A. A proposição conseqüente terá forma diferenciada, dependendo do modelo nebuloso adotado:

- modelo nebuloso lingüístico (tipo Mamdani): o conseqüente é também uma proposição nebulosa.

- modelo nebuloso de Takagi-Sugeno (TS): o conseqüente é uma função linear.

\subsubsection{Modelo do tipo Mamdani}

As regras de um modelo nebuloso do tipo Mamdani podem ser representadas da seguinte forma:

$R_{i}:$ Se $\boldsymbol{x}$ for $A_{i}$ então $y=B_{i}, i=1,2, \ldots, k$,

onde: $A_{i}$ e $B_{i}$ são valores lingüísticos

$x$ é variável lingüística de entrada

$y$ é variável lingüística de saída

Um modo de se obter a saída neste tipo de modelo nebuloso é fazer a média ponderada da saída "crisp" de cada regra submetida às respectivas intensidades de disparo (o produto ou o mínimo dos graus de pertinência do termo antecedente) e às funções de pertinência da saída. As funções de pertinência usadas neste procedimento devem ser monotônicas. Outra forma de se obter a saída deste sistema de inferência nebulosa é aplicar a operação "max" às saídas nebulosas qualificadas (cada uma é igual ao mínimo de intensidade de disparo e à função de pertinência de cada regra). Várias abordagens podem ser utilizadas para a obtenção da saída "crisp" com base na saída nebulosa total, como por exemplo o centróide de área , bissetor de área, média de máximo, critério de máximo, etc. 


\subsubsection{Modelo de Takagi-Sugeno (TS)}

O modelo nebuloso de TS (Takagi e Sugeno, 1985) pode ser visto como uma combinação de modelagem lingüística e de regressão matemática, visto que os antecedentes descrevem regiões nebulosas no espaço de entrada nas quais as funções conseqüentes são válidas. As regras TS têm a seguinte forma:

$R_{i}:$ Se $\boldsymbol{x}$ for $A_{i}$ então $y_{i}=f_{i}(x), i=1,2, \ldots, k$

As funções $\boldsymbol{f}_{\boldsymbol{i}}$ são geralmente da mesma estrutura, sendo somente os parâmetros em cada regra são diferentes. Uma parametrização simples e prática é a forma afim (linear nos parâmetros):

$R_{i}:$ Se $\boldsymbol{x}$ for $A_{i}$ então $y_{i}=a_{i}{ }^{T} \boldsymbol{x}+b_{i}, i=1,2, \ldots, k$,

onde $\boldsymbol{a}_{\boldsymbol{i}}$ é um vetor de parâmetros e $\boldsymbol{b}_{\boldsymbol{i}}$ é um termo escalar.

A saída de cada regra, então, é uma combinação linear das variáveis de entrada mais um termo constante e a saída final é a média ponderada de cada saída de regra (conforme figura 3.1). Portanto, a saída de cada regra pode ser considerada uma função linear local, ou seja, um hiperplano local dentro do hiperespaço considerado.
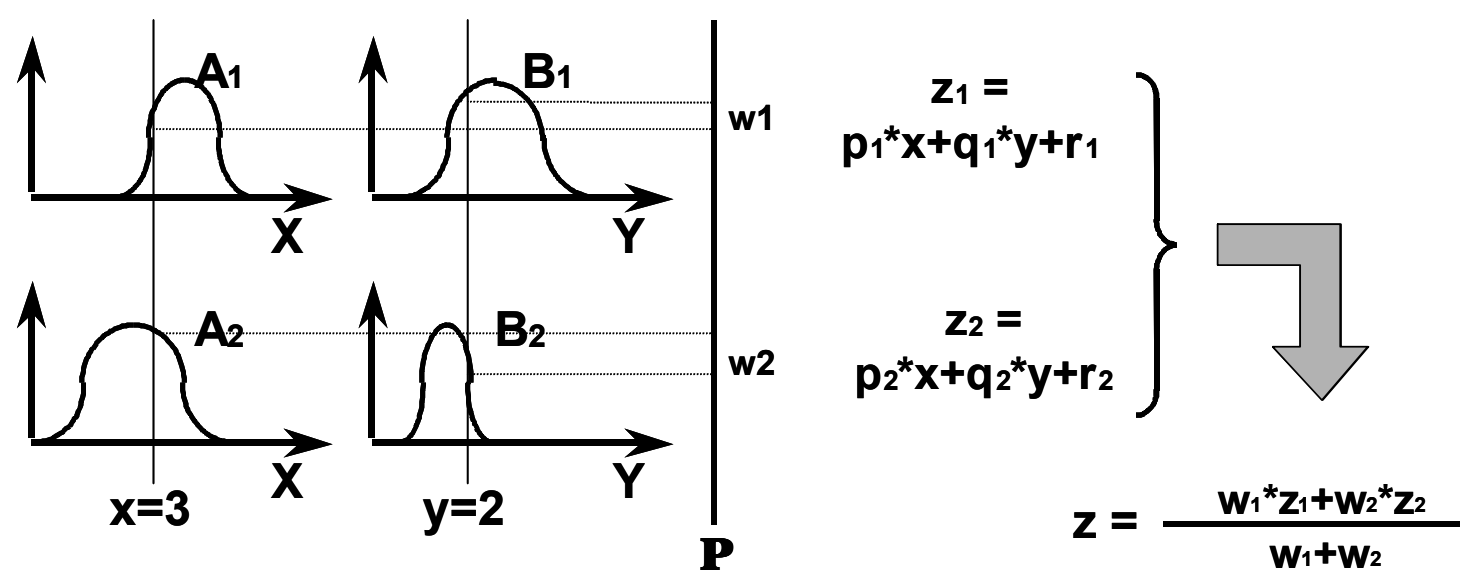

Figura 3.1. Representação de obtenção de saída para modelo TS 


\subsubsection{Construção de modelos nebulosos}

As duas fontes mais comuns de informação para a construção de modelos nebulosos são o conhecimento prévio do processo a ser modelado e dados (medidas do processo). O conhecimento prévio pode ser de natureza aproximada (informação qualitativa) proveniente de especialistas (projetistas, operadores, entre outros).

Os dados de processo podem ser obtidos tanto de forma automática (através de registros históricos armazenados por um programa supervisório) bem como através de medidas laboratoriais (em processos bioquímicos, por exemplo). A construção de modelos nebulosos através de dados do processo compreende métodos baseados em lógica nebulosa e raciocínio aproximado, mas também idéias oriundas do campo das redes neuronais, análise de dados e identificação convencional de sistemas. A aquisição ou sintonia de modelos nebulosos por intermédio de dados do processo é geralmente denominada de identificação nebulosa.

Podem ser destacadas duas formas de integração de conhecimento prévio e dados de processo em um modelo nebuloso:

- O conhecimento prévio do especialista é condensado em um conjunto de regras se-então. Dessa maneira, é criada uma certa estrutura do modelo. Os parâmetros dessa estrutura (funções de pertinência e parâmetros) podem ser sujeitos a um ajuste fino usando dados de entrada-saída. Os algoritmos de sintonia exploram o fato de que no nível computacional, um modelo nebuloso pode ser visto como uma estrutura em camadas (rede), similar a redes neuronais artificiais, para as quais podem ser aplicados algoritmos de aprendizado. Essa forma é geralmente denominada modelagem neuro-fuzzy (Jang, 1993).

- Nenhum conhecimento prévio do processo sob estudo é utilizado inicialmente para formular as regras e é construído um modelo nebuloso por intermédio de dados do processo. Espera-se que as regras extraídas e as funções de pertinência possam proporcionar uma interpretação posterior do comportamento do sistema. 
Essas técnicas podem ser combinadas, dependendo da aplicação. A seguir, são destacados os principais passos para a construção de um modelo nebuloso baseado em conhecimento e as técnicas principais para extrair uma sintonia fina dos modelos nebulosos por intermédio de dados do processo.

a- Estrutura e parâmetros

A estrutura determina a flexibilidade do modelo para a aproximação. Os parâmetros são então estimados para que se ajustem aos dados do processo. Um modelo com uma estrutura satisfatória deve ser capaz de aproximar funções mais complicadas, embora possua propriedades de generalização piores. Uma boa generalização acontece quando um modelo construído para um determinado conjunto de dados de processo é validado para outro conjunto de dados do mesmo processo.

A seleção de modelos nebulosos deve levar em consideração os seguintes fatores para a escolha de sua estrutura:

- Variáveis de entrada e saída: Em sistemas complexos, nem sempre é evidente quais são as variáveis que devem ser utilizadas como entradas do modelo. No caso de sistemas dinâmicos, deve-se estimar a ordem do sistema. No caso de modelagem nebulosa, o conhecimento prévio do processo a ser modelado, a percepção de seu comportamento e o propósito da modelagem são as típicas fontes de informação para essa escolha.

- Estrutura das regras: Envolve o tipo de modelo (Mamdani ou Takagi-Sugeno) e a forma do antecedente.

- Número e tipo de funções de pertinência de cada variável: Determina o nível de detalhe do modelo. $\mathrm{O}$ propósito da modelagem e o detalhe do conhecimento disponível influenciará essa escolha. 
- Tipo do mecanismo de inferência, operadores e método de defuzzificação: Essas escolhas são restringidas pelo tipo do modelo nebuloso (Mamdani, TS). Apesar dessas restrições, alguma liberdade de escolha ainda permanece como, por exemplo, os operadores (mínimo, máximo, produto, soma, ...).

Depois que se escolhe uma estrutura, o modelo nebuloso pode ter seus parâmetros ajustados para a obtenção de um comportamento mais aproximado do processo real. Portanto, há uma otimização dos parâmetros antecedentes e conseqüentes, o que em modelos lingüísticos como os do tipo Mamdani implica no ajuste fino da forma e posição das funções de pertinência bem como de quais regras serão significativas. Os modelos de Takagi-Sugeno, além dos parâmetros antecedentes ajustados de modo similar aos do tipo Mamdani, têm também os parâmetros de suas funções conseqüentes otimizados.

b- Projeto baseado em conhecimento

Babuska (2001) argumenta que para projetar um modelo nebuloso baseado em conhecimento disponível do especialista, os seguintes passos podem ser seguidos:

1. Selecionar as variáveis de entrada e saída, a estrutura das regras e os métodos de inferência e defuzzificação.

2. Decidir o número de termos lingüísticos para cada variável e definir as funções de pertinência correspondentes.

3. Representar o conhecimento disponível nos termos de regras nebulosas se-então. 
4. Validar o modelo (por exemplo ao usar dados de teste). Se o modelo não tiver uma resposta adequada, repetir os passos acima.

Deve ser ressaltado que o bom desempenho desse método depende do problema em questão e a quantidade e qualidade do conhecimento disponível. Para alguns problemas, o projeto baseado em conhecimento pode proporcionar modelos rápidos e úteis, enquanto para outros pode ser um procedimento ineficiente e moroso (especialmente quando é necessário um ajuste fino dos parâmetros do modelo). Portanto, é interessante combinar o projeto baseado em conhecimento com uma sintonia baseada em um conjunto de dados dos parâmetros do processo.

\subsubsection{Modelagem neuro-nebulosa (neuro-fuzzy)}

Jang (1993) propôs um tipo de modelagem nebulosa que utiliza uma estrutura de redes neuronais adaptativas em conjunto com estimativas de mínimos quadrados para a implementação de sistemas nebulosos. A utilização desta estrutura com tal objetivo se deve à inexistência de métodos padronizados de transformar conhecimento humano em uma base de regras de um sistema de inferência nebuloso bem como à necessidade de métodos eficientes para o ajuste das funções de pertinência e conseqüente minimização do erro de saída. Nesse sentido, a arquitetura Sistema de Inferência Nebulosa de Redes Adaptativas (ANFIS, em Inglês) pode ser uma ferramenta poderosa para a construção de um conjunto de regras nebulosas se-então com funções de pertinência adequadas.

Considerando-se, por exemplo, um sistema de inferência nebulosa de duas entradas, $x$ e $y$ e uma saída $z$, sendo composto por duas regras nebulosas de Takagi-Sugeno, tem-se:

Regra 1: Se x for $A_{1}$ e y for $B_{1}$, então $f_{1}=p_{1} x+q_{1} y+r_{1}$,

Regra 2: Se x for $A_{2}$ e y for $B_{2}$, então $f_{2}=p_{2} x+q_{2} y+r_{2}$ 
Então, a estrutura de Takagi-Sugeno pode ser representada pela figura 3.2.

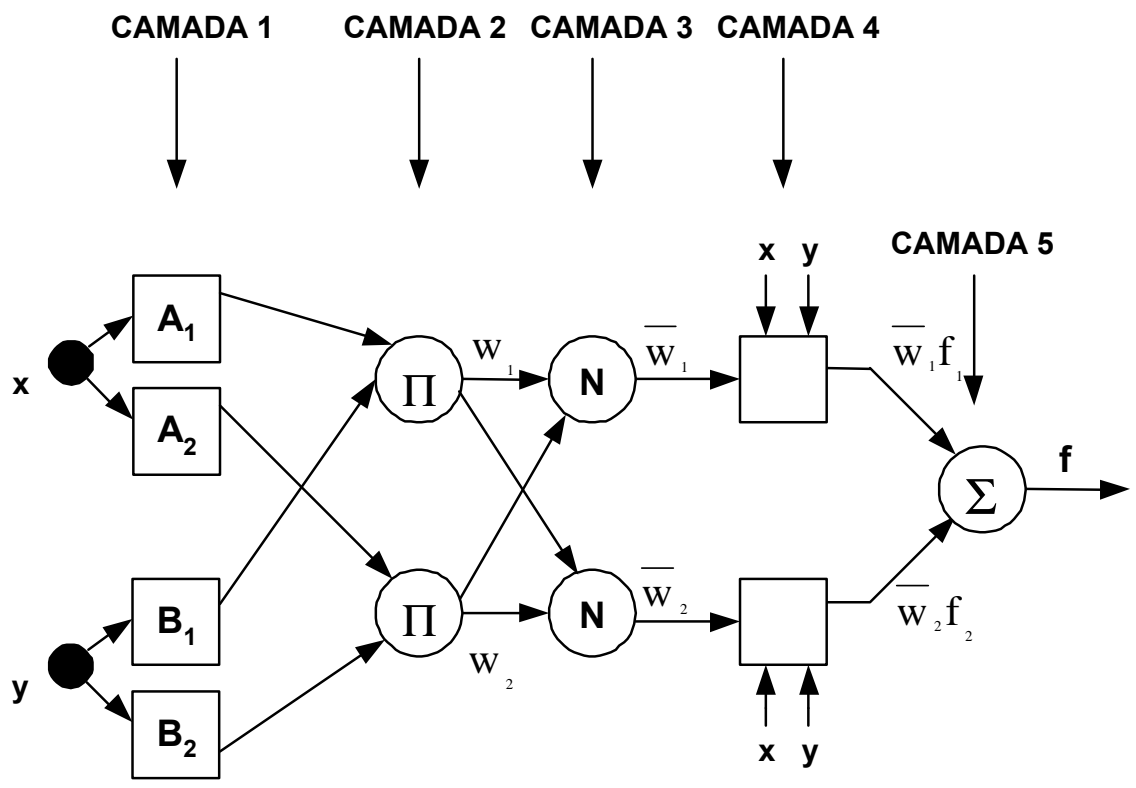

Figura 3.2. Equivalente ANFIS

As funções nó das camadas são da mesma família de funções conforme descrito abaixo:

Camada 1: Todo nó dessa camada é quadrado (possui parâmetros que podem ser ajustados) com uma função nó:

$O_{i}^{l}=\mu_{A_{i}}(x)$

onde $x$ é a entrada para o nó $i$ e $A_{i}$ é o valor lingüístico (alto, baixo, etc.) associado a essa função nó. Ou seja, $O_{i}{ }^{l}$ é a função de pertinência de $A_{i}$ e especifica o grau pelo qual um dado valor $x$ pertence ao conjunto $A_{i}$. Geralmente, é escolhida uma função de pertinência do tipo formato de sino que excursiona entre 0 e 1 , tal como:

$\mu_{A_{i}}(x)=\frac{1}{1+\left[\left(\frac{x-c_{i}}{a_{i}}\right)^{2}\right]^{b i}}$ 
onde $\left\{a_{i}, b_{i}, c_{i}\right\}$ é o conjunto de parâmetros antecedentes. Como os valores desses parâmetros mudam, as funções de pertinência seguem a mesma dinâmica, exibindo várias formas de funções de pertinência sobre o termo lingüístico $A_{i}$. De fato, funções de pertinência triangulares, trapezoidais ou gaussianas são também candidatas a serem funções de nó dessa camada. Os parâmetros dessa camada são denominados como antecedentes.

Camada 2: Todo nó dessa camada é circular (sem parâmetros ajustáveis) e tem como saída o produto dos sinais de entrada. Por exemplo:

$w_{i}=\mu_{A_{i}}(x) X \mu_{B_{i}}(x), \quad i=1,2$.

Cada saída de nó representa a intensidade de disparo de uma regra (outras formas de operadores T-norma que executam o $\mathbf{E}$ também podem ser utilizados como uma função nó nessa camada).

Camada 3: Todo nó dessa camada é circular. O iésimo nó calcula a razão da intensidade de disparo da i-ésima regra pela soma das intensidades de disparo de todas as regras:

$$
\overline{w_{i}}=\frac{w_{i}}{w_{1}+w_{2}}, \quad i=1,2
$$

As saídas dessa camada são denominadas de intensidades de disparo normalizadas.

Camada 4: Todo nó dessa camada é quadrado com uma função nó:

$$
O_{i}^{4}=\overline{w_{i}} f_{i}=\overline{w_{i}}\left(p_{i} x+q_{i} y+r_{i}\right)
$$

onde $\overline{w_{i}}$ é a saída da camada 3 e $\left\{p_{i}, q_{i}, r_{i}\right\}$ é o conjunto de parâmetros. Os parâmetros dessa camada são denominados de conseqüentes. 
Camada 5: O nó único dessa camada é circular representado pelo símbolo de somatório e calcula a saída como a soma de todos os sinais de entrada:

$O_{i}^{5}=\sum_{i} \overline{w_{i}} f_{i}=\frac{\sum_{i} w_{i} f_{i}}{\sum_{i} w_{i}}$

O software Matlab possui uma ferramenta ANFIS que utilizando uma estrutura de rede tal qual uma rede neuronal (Figura 3.1), mapeia as entradas através de funções de pertinência de entrada e parâmetros associados bem como as funções de saída e seus respectivos coeficientes. Os parâmetros associados a estas funções mudam durante o processo de aprendizado. O cálculo desses parâmetros é obtido através de um vetor gradiente, que proporciona uma avaliação de como o sistema de inferência nebuloso está modelando os dados de entrada e saída para um determinado conjunto de parâmetros. Uma vez obtido o vetor gradiente, podem ser aplicadas quaisquer das várias rotinas de otimização para ajustar os parâmetros com o propósito de reduzir um determinado erro (normalmente erros quadráticos). A ferramenta ANFIS utiliza retro-propagação ou mesmo uma combinação de estimação de mínimos quadrados e retro-propagação para estimar os parâmetros das funções (toolbox do Matlab).

\subsubsection{Modelagem baseada em técnicas de discretização nebulosa}

Wang e Langari (1996) utilizaram técnicas de discretização nebulosa como uma ferramenta para modelagem de processos. A idéia básica dessa técnica de modelagem reside na partição de um espaço real $\Omega \rightarrow[0,1]$ em conjuntos nebulosos $R_{1}, R_{2}, \ldots, R_{c}$, intitulados "conjuntos nebulosos de referência, que satisfaçam a seguinte condição:

$\forall x \in \Omega \quad \exists 1 \leq i \leq c$, tal que $\mu_{R_{i}}(x)>0$

sendo que cada ponto de $\Omega$ pertence ao menos a um $\operatorname{dos} R_{i}$. 
Os conjuntos nebulosos de referência podem ser gerados de diferentes formas: estatística ou definido pelos conhecimentos do usuário. Neste caso, empregou-se o método de clusterização e, em particular, o algoritmo de clusterização fuzzy c-means (Hellendoorn e Driankov, 1997).

Assim, para um determinado conjunto de pontos $A=\left\{x_{1}, x_{2}, \ldots, x_{n}\right\}$, cada ponto $x_{i}$ possui um grau de pertinência associado a cada cluster, formando a matriz cxn de partição dos agrupamentos nebulosos $U=\left[\mu_{i k}\right]$, cujas entradas satisfazem as seguintes condições:

$$
\sum_{i=1}^{c} \mu_{i k}=1 . \quad k=1,2, \ldots, n
$$

sendo c o número de pontos do conjunto A.

$0<\sum_{i=1}^{n} \mu_{i k}<n . i=1,2, \ldots, c$

sendo c o número de clusters.

onde $\mu_{i k}$ é o grau de pertinência de $x_{k}$ no $i$-ésimo agrupamento. $\mathrm{O}$ elemento da matriz de pertinência $\mu_{i k}$ é calculado pelo algoritmo FCM ao minimizar uma determinada função objetivo, que resulta

$$
\begin{aligned}
& \mu_{i k}=\sum_{j=1}^{c}\left[\left(\frac{\mathrm{x}_{\mathrm{k}}-z_{\mathrm{i}}}{x_{\mathrm{k}}-z_{\mathrm{j}}}\right)^{2 /(m-l)}\right]^{-1}, i=1,2, \ldots, c, k=1,2, \ldots, n \\
& \operatorname{para} x_{k}-z_{i} \neq 0 .
\end{aligned}
$$

$\mathrm{ou}$

$$
\sum_{i=1}^{n} \mu_{i k}=0\left(\text { para } x_{k}-z_{i}=0\right), \quad i=1,2, \ldots, c \quad k=1,2, \ldots, n
$$


onde $m>1$ é um parâmetro de projeto e $z_{i}$ é o valor médio dos clusters nebulosos (fuzzy mean), sendo calculado como:

$$
z_{i}=\frac{\sum_{k=1}^{n} x_{k}\left(\mu_{i k}\right)^{m}}{\sum_{k=1}^{n}\left(\mu_{i k}\right)^{m}}, \quad i=1,2, \ldots, c
$$

Por exemplo, seja:

$$
\begin{aligned}
& R_{1} \text { : se } u_{1}^{k} \text { for } \mu_{11}^{k} \text { e ...e } u_{p}^{k} \text { for } \mu_{1 p}^{k} \text { então } y_{1}^{k}=b_{10}+b_{11} u_{1}^{k}+\ldots+b_{1 p}^{k} u_{p}^{k} \\
& R_{2} \text { : se } u_{2}^{k} \text { for } \mu_{21}^{k} \text { e ...e } u_{p}^{k} \text { for } \mu_{2 p}^{k} \text { então } y_{2}^{k}=b_{20}+b_{21} u_{1}^{k}+\ldots+b_{2 p}^{k} u_{p}^{k} \\
& \text { - } \\
& \text { - } \\
& R_{h} \text { : se } u_{1}^{k} \text { for } \mu_{h 1}^{k} \text { e ...e } u_{p}^{k} \text { for } \mu_{h p}^{k} \text { então } y_{h}^{k}=b_{h 0}+b_{h 1} u_{1}^{k}+\ldots+b_{h p}^{k} u_{p}^{k}
\end{aligned}
$$

sendo $h=1,2, \ldots n$,

onde $p$ é o número de variáveis de entrada, $h$ o número de dados de entrada-saída e $\mathrm{n}$ é o número de regras dado por $c^{p}:\left\{u_{1}^{k}, u_{2}^{k}, \ldots, u_{p}^{k}\right\}$ e $\left\{y_{1}^{k}, y_{2}^{k}, \ldots, y_{h}^{k}\right\}$ são as variáveis de entrada e saída, respectivamente; $\mu_{i j}^{k}(i=1,2, \ldots, h, j=1,2, \ldots, p)$ são os graus de pertinência das variáveis de entrada. Essa formulação, como pode ser observado, tem a estrutura proposta por Takagi-Sugeno.

Para a obtenção dos parâmetros antecedentes, é utilizada a técnica de discretização nebulosa proposta acima. $\mathrm{O}$ cálculo das funções de pertinência das variáveis de entrada é realizado através da construção de conjuntos nebulosos de referência usando o método de clusterização nebulosa. É importante ressaltar que os parâmetros antecedentes são obtidos de forma independente dos parâmetros conseqüentes, o que simplifica consideravelmente o processo de construção do modelo de TakagiSugeno. Em outras palavras, toda a informação sobre as funções de pertinência das 
entradas é carregada pela matriz de partição $U=\left[\mu_{i j}\right]$, onde $i=1,2, \ldots, h, j=1,2, \ldots, p$ e $k=1,2, \ldots, n$. Dessa maneira, as funções de pertinência das variáveis de entrada são obtidas implicitamente.

Supõe-se, nesse método que as variáveis de entrada tenham todas o mesmo número de conjuntos nebulosos de referência (clusters nebulosos).

Os parâmetros consequentes são calculados como se segue:

$$
y^{k}=\frac{\sum_{i=1}^{h} w_{i}^{k} y_{i}^{k}}{\sum_{i=1}^{h} w_{i}^{k}}
$$

onde

$$
w_{i}^{k}=\mu_{i 1}^{k} \wedge \mu_{i 2}^{k} \wedge \ldots \wedge \mu_{i r}^{k}
$$

Definindo-se:

$$
v_{i}^{k}=\frac{w_{i}^{k}}{\sum_{i=1}^{h} w_{i}^{k}}
$$

então $y^{k}$ pode ser reescrito como:

$$
y^{k}=\sum_{i=1}^{h} v_{i}^{k} y_{i}^{k}=\sum_{i=1}^{h} v_{i}^{k}\left(b_{i 0}+b_{i 1} u_{1}^{k}+\ldots+b_{i p}^{k} u_{p}^{k}\right)
$$

Os parâmetros $b_{i j}(i=1,2, \ldots, h e j=0,1, \ldots, p)$ são estimados pela minimização da seguinte função objetivo: 
$J=\sum_{k=1}^{n}\left(y^{k}-\sum_{i=l}^{l} v_{i}^{k} y_{i}^{k}\right)^{2}=\|y-\phi b\|^{2}$

onde

$$
\begin{aligned}
& y=\left[y^{1} y^{2} \ldots y^{n}\right]^{T}=\left[y_{1} y_{2} \ldots y_{n}\right]^{T} \\
& b=\left[b_{10} \ldots b_{h 0} b_{11} \ldots b_{h 1} \ldots b_{1 p} \ldots b_{h p}\right]^{T}
\end{aligned}
$$

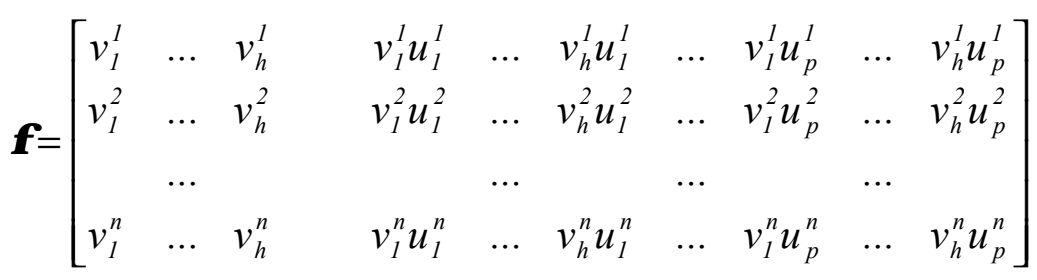

O vetor de parâmetros conseqüentes das funções de Takagi-Sugeno é calculado por

$$
b=\left(\phi^{T} \phi\right)^{-1} \phi^{T} y
$$

Para resolver a equação para cálculo dos parâmetros conseqüentes é proposto o seguinte conjunto de equações recursivas:

$$
\begin{aligned}
& f_{k}=C_{k-1}^{T} \varphi_{k}^{T} \\
& \tilde{a}_{k}=\left[1+f_{k}^{T} f_{k}\right]^{1 / 2} \\
& \dot{a}_{k}=\tilde{a}_{k}+1 \\
& \hat{a}_{k}=\frac{1}{\left(\tilde{a}_{k} \hat{a}_{k}\right)} \\
& \dot{o}_{k}=\hat{a}_{k} C_{k-1} f_{k} \\
& b_{k}=b_{k-1}+\dot{o}_{k}\left\{\frac{\tilde{a}_{k}}{\tilde{a}_{k}}\left(y_{k}-\ddot{o}_{k} b_{k-1}\right)\right\}
\end{aligned}
$$


$C_{k}=C_{k-1}-o_{k} f_{k}^{T}$

onde

$\varphi_{k}$ é a késima linha de $\varphi$

$C_{k}$ é a decomposição de Cholesky de $P_{k}$

$P_{k}=\left(\sum_{i=1}^{k} \ddot{o}_{i}^{T} \ddot{o}\right)^{-1}$

Portanto, esse algoritmo, no que se refere ao cálculo dos parâmetros antecedentes, obtém os graus de pertinência de cada ponto em relação a cada cluster de cada variável. Apesar da simplificação efetuada no cálculo dos parâmetros antecedentes e consequientes, o cálculo dos parâmetros antecedentes limita o algoritmo a uma estrutura de modelo para um pequeno número de variáveis de entrada e de clusters. Essa limitação ocorre devido à sobrecarga de esforço computacional, o que implica em lentidão de processamento e freqüentes problemas de consumo exagerado de memória (a maldição da dimensionalidade), visto que o acréscimo de variáveis de entrada e/ou de clusters produz um aumento exponencial de regras.

\subsubsection{Modelagem baseada em técnicas de discretização nebulosa com número limitado de regras}

Para contornar a limitação do modelo baseado em técnicas de discretização nebulosa, foi desenvolvido pelo aluno Carlos Eduardo Neri de Oliveira do Laboratório de Automação e Controle (LAC) da Escola Politécnica da Universidade de São Paulo uma variante desse algoritmo, que tem como principal atrativo a limitação do número de regras nebulosas.

A modificação empregada se baseia no conceito da não utilização de valores discretos das variáveis de entrada e seus respectivos graus de pertinência associados a clusters particulares de cada variável, mas sim ao estabelecimento de vetores de pontos que terão graus de pertinência maiores ou menores dependendo de sua 
distância a um centro de cluster $v_{i}$ no espaço $\mathfrak{R}^{\mathrm{p}}$. Esses graus de pertinência determinam a intensidade de disparo de cada regra. A pertinência de um ponto a um cluster pode ser calculada por:

$\mu_{i k}=\frac{1}{\sum_{j=1}^{c}\left(d_{k i} / d_{k j}\right)^{2 /(m-l)}}$

sendo $d_{i k}=\left\|z_{k}-v_{i}\right\|$

onde:

$z_{k}$ é o $k$-ésimo ponto

$v_{i}$ é o $i$-ésimo centro de cluster

Nesse modelo, cada cluster é associado a uma regra, de forma que o número de regras será sempre igual ao número de clusters. Os parâmetros conseqüentes são calculados através da minimização da somatória dos erros quadráticos. 


\section{Capítulo 4. \\ Desenvolvimento do Trabalho}

\subsection{Descrição da planta}

O benchmark da planta de lodos ativados tem a configuração da figura 4.1. O reator biológico possui uma zona anóxica (sem a presença de OD) devido à sua característica de remoção de nitrogênio (Van Haandel e Marais, 1999).

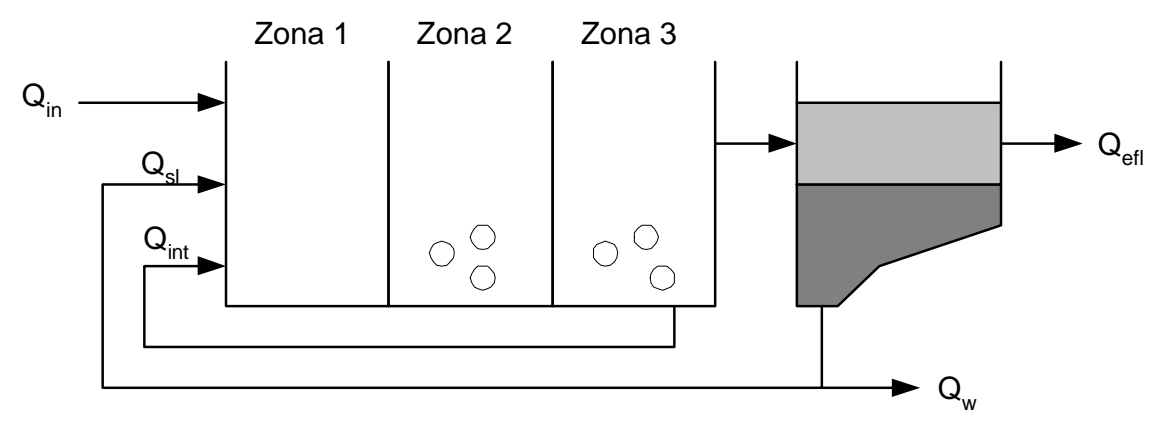

Figura 4.1. Configuração do benchmark ASWWTP-USP

A configuração da planta mostrada na figura 4.1 é uma planta de lodos ativados com pré-desnitrificação formada por um bioreator (composto de uma zona anóxica e duas aeróbias) e um decantador secundário. Cada uma das câmaras do bioreator tem um volume constante $\left(13 \mathrm{~m}^{3}, 18 \mathrm{~m}^{3}\right.$ e $20 \mathrm{~m}^{3}$, respectivamente) e é considerado um processo de mistura completa, ao passo que o decantador secundário (volume $=20 \mathrm{~m}^{3}$ ) é modelado como uma série de 10 camadas (um modelo uni-dimensional). $\mathrm{Na}$ operação nominal, a vazão média afluente, $Q_{i n}$, é $4,17 \mathrm{~m}^{3} / \mathrm{h}$, com uma concentração média de DQO rapidamente biodegradável, $S_{S}$, de $224 \mathrm{mg} / \mathrm{L}$ e um tempo de detenção hidráulica de 17,0 $h$ (para o volume total, isto é, bioreator mais decantador secundário). A vazão de recirculação interna é $Q_{i n t}=2 Q_{i n}$, a vazão de lodo de retorno é $Q_{s l}=0,5 Q_{i n}$ e a vazão de descarte de lodo é $Q_{W}=0,0258 \mathrm{~m}^{3} / \mathrm{h}$. As vazões de ar são $Q_{a r_{-} 2}=0,044 \mathrm{~m}^{3} / \mathrm{h}$ e $Q_{a r_{-} 3}=0,033 \mathrm{~m}^{3} / \mathrm{h}$ para a primeira zona aeróbia e a segunda zona aeróbia, respectivamente, sendo nula a vazão de ar na zona anóxica . Os valores dos 
parâmetros cinéticos do processo e demais variáveis de entrada são omitidos aqui, mas podem ser achados em Sotomayor et al. (2001).

\subsection{Construção do modelo nebuloso}

\subsubsection{Escolha das variáveis de entrada}

A construção do modelo nebuloso, como nos métodos de modelagem convencionais, deve seguir procedimentos adequados. O mais fundamental deles é a escolha das variáveis de entrada. No caso da modelagem proposta, procura-se o estabelecimento de variáveis de entrada que afetem diretamente o comportamento da concentração de oxigênio dissolvido. Algumas variáveis, somente com os conceitos consolidados sobre o processo de tratamento de esgotos por lodos ativados, poderiam ser escolhidas como entradas do modelo sem a necessidade da observação do comportamento da variável de saída a partir de uma perturbação imposta sobre as

primeiras. É o caso, por exemplo, da concentração de amônia afluente, que como já foi ressaltado neste texto, tem sua transformação a nitrito e nitrato (nitrificação) e em seqüência a nitrogênio gasoso (desnitrificação) alterando significativamente o perfil de OD no bioreator de tal planta. Outro exemplo de variável de entrada que pode ser considerada nesta modelagem com base somente nos conceitos de tratamento de esgotos por lodos ativados é a concentração de substrato rapidamente biodegradável afluente. Como tal alimento é facilmente degradado pelos microrganismos presentes no esgoto, percebe-se que quando sua concentração se altera significativamente, há uma mudança nas taxas de seu metabolismo, provocando alterações na dinâmica do OD. Através das figuras 4.2 e 4.3 observa-se que durante o tempo de simulação, para um aumento na concentração de amônia afluente de $100 \%$ a concentração de OD é reduzida de $35 \%$ (de 2,0 mg/L para 1,3 mg/L). Nas figuras 4.4 e 4.5, é constatada uma redução de $12,5 \%$ na concentração de OD para um aumento de concentração de substrato rapidamente biodegradável afluente de 100\%. Outras variáveis de entrada do benchmark, como é o caso da vazão de ar na segunda zona aeróbia, da vazão de recirculação de lodo e a vazão de esgotos afluente, também podem ser utilizadas 
como variáveis de entrada do modelo nebuloso (figuras 4.6 a 4.11). A vazão de ar pelo seu impacto direto na transferência de oxigênio para o líquido e a vazão de recirculação e a vazão de esgotos afluente por ser variável fundamental na alteração da concentração da população de microrganismos no tanque de aeração. Como as estações de tratamento de esgotos por lodos ativados no Brasil não são configuradas para remoção de nitrogênio, optou-se por não utilizar como variável de entrada a vazão de ar na $1{ }^{a}$ zona aeróbia, mantendo-a constante em seu valor nominal. As demais variáveis de entrada observadas não demonstraram impacto significativo com excursões de mesma faixa que aquelas supra-citadas, sendo mantidas constantes em seu valor nominal.

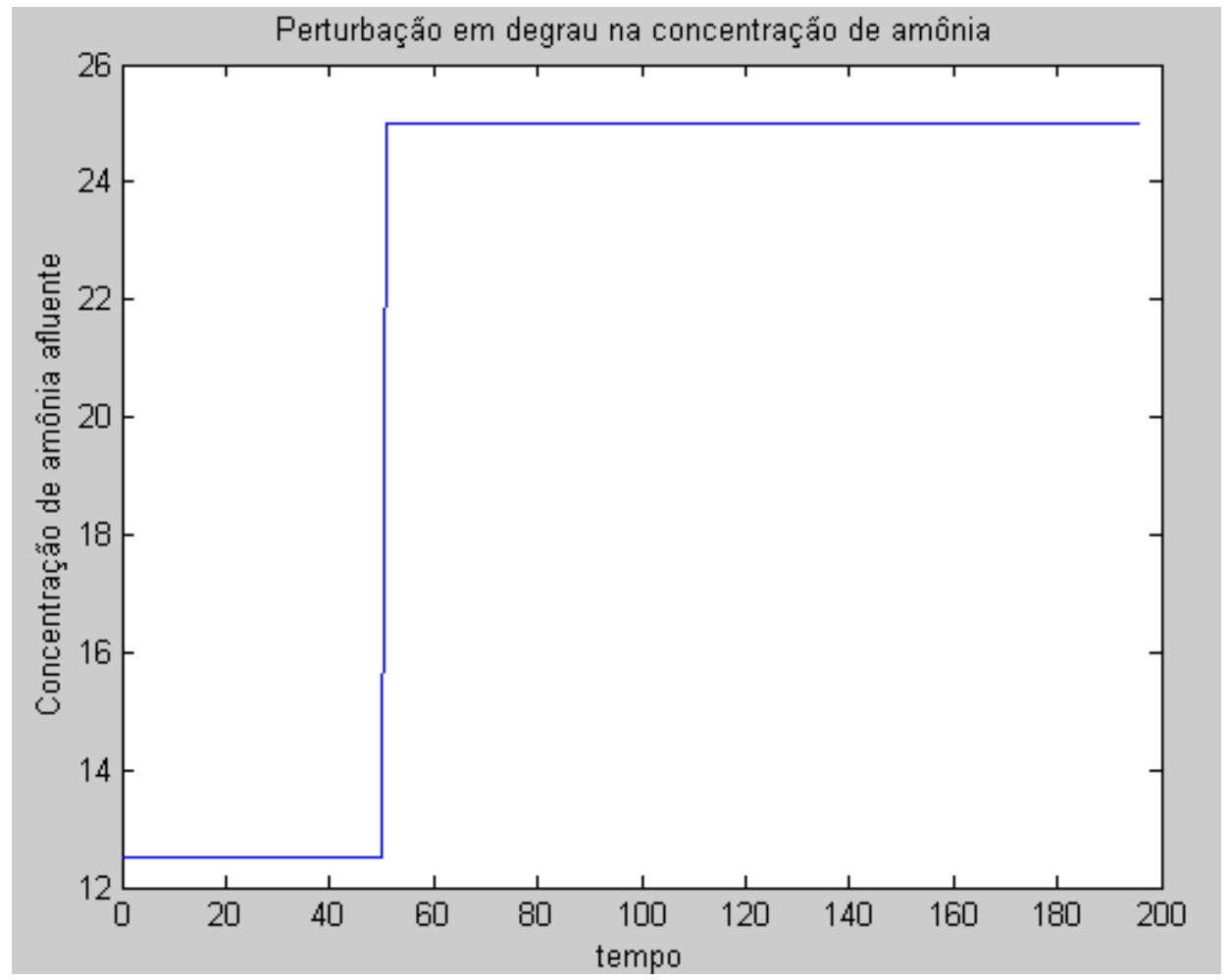

Figura 4.2. Perturbação em degrau na concentração de amônia afluente 


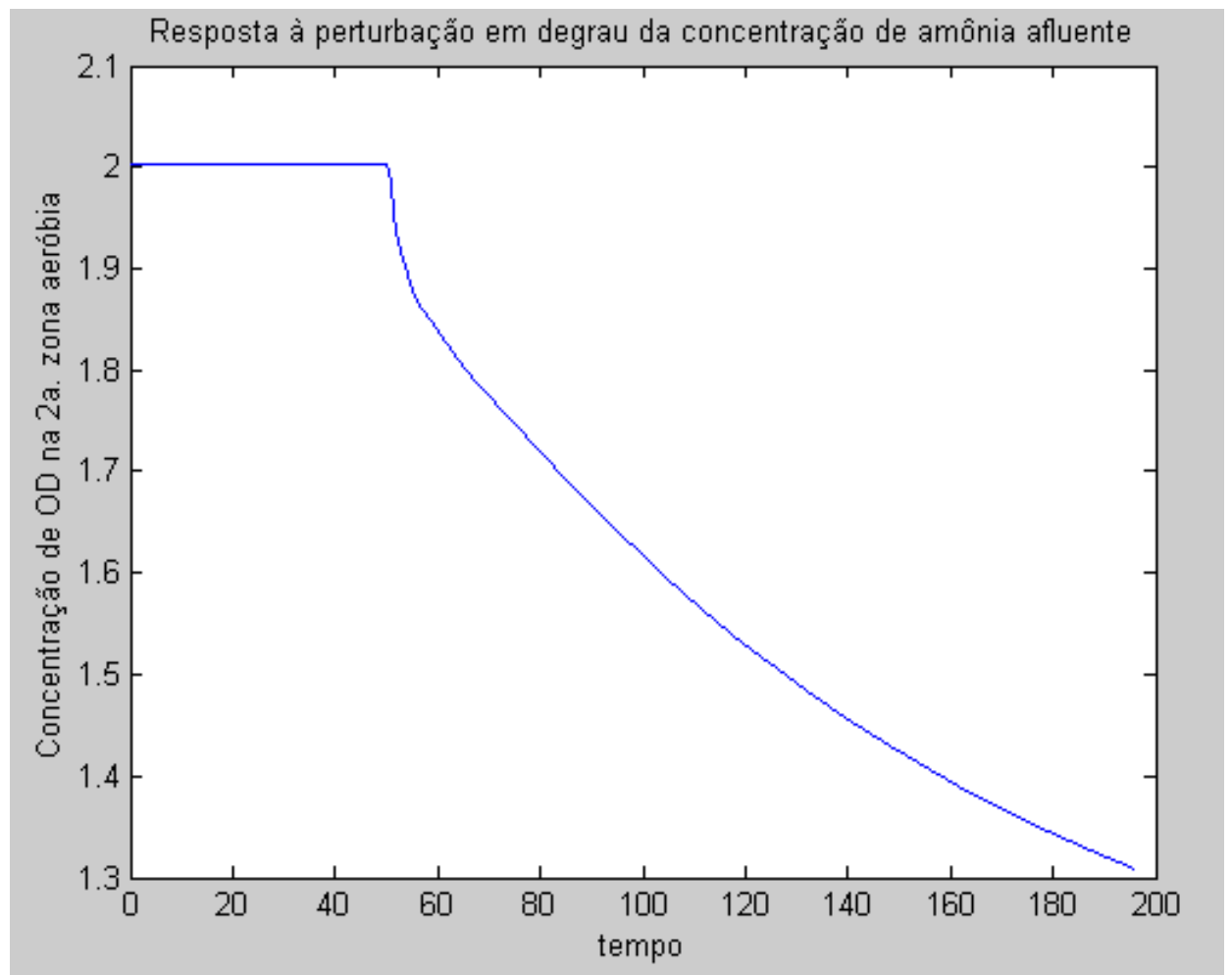

Figura 4.3. Resposta do OD à perturbação em degrau na concentração de amônia afluente

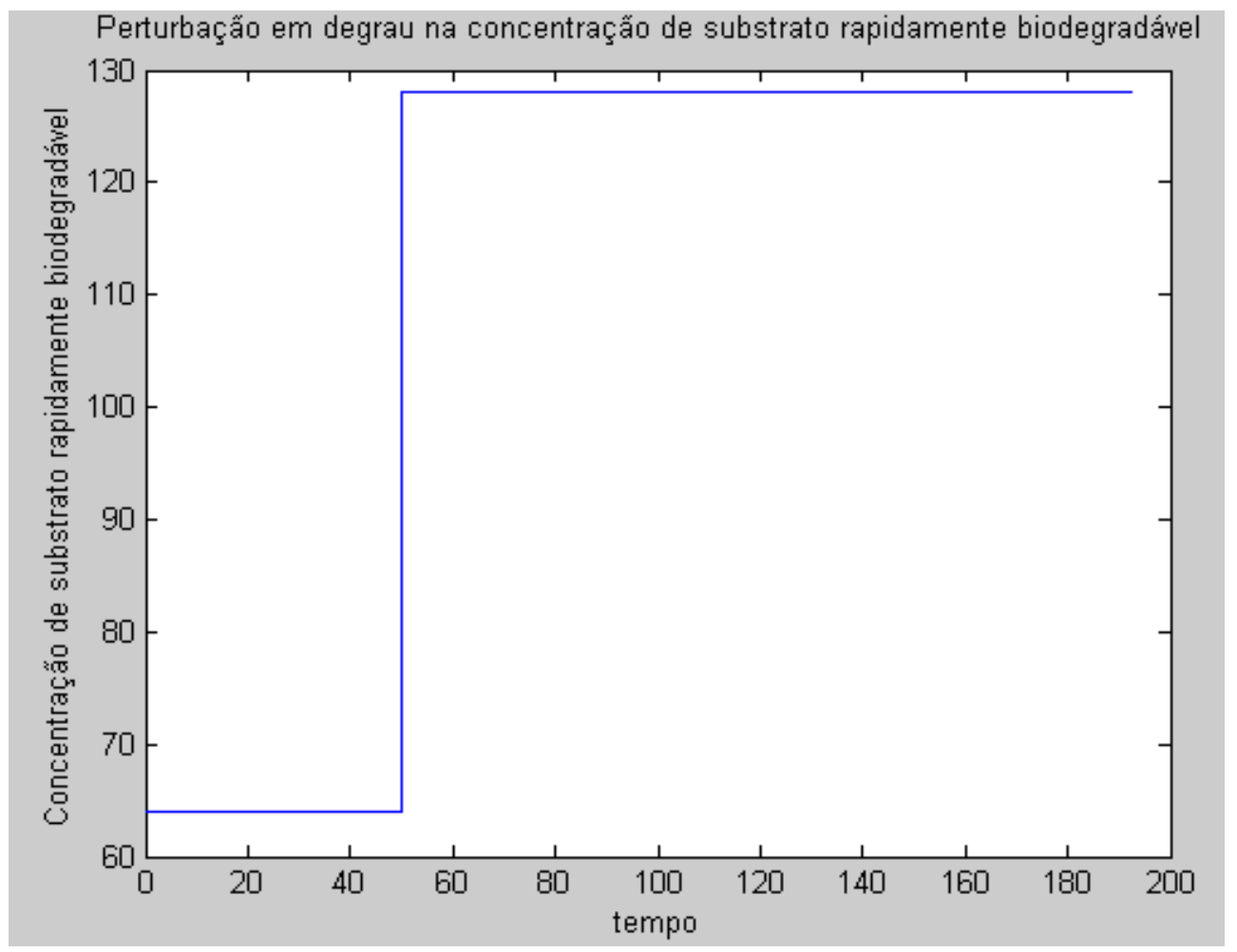

Figura 4.4. Perturbação em degrau na concentração afluente de $S_{S}$ 


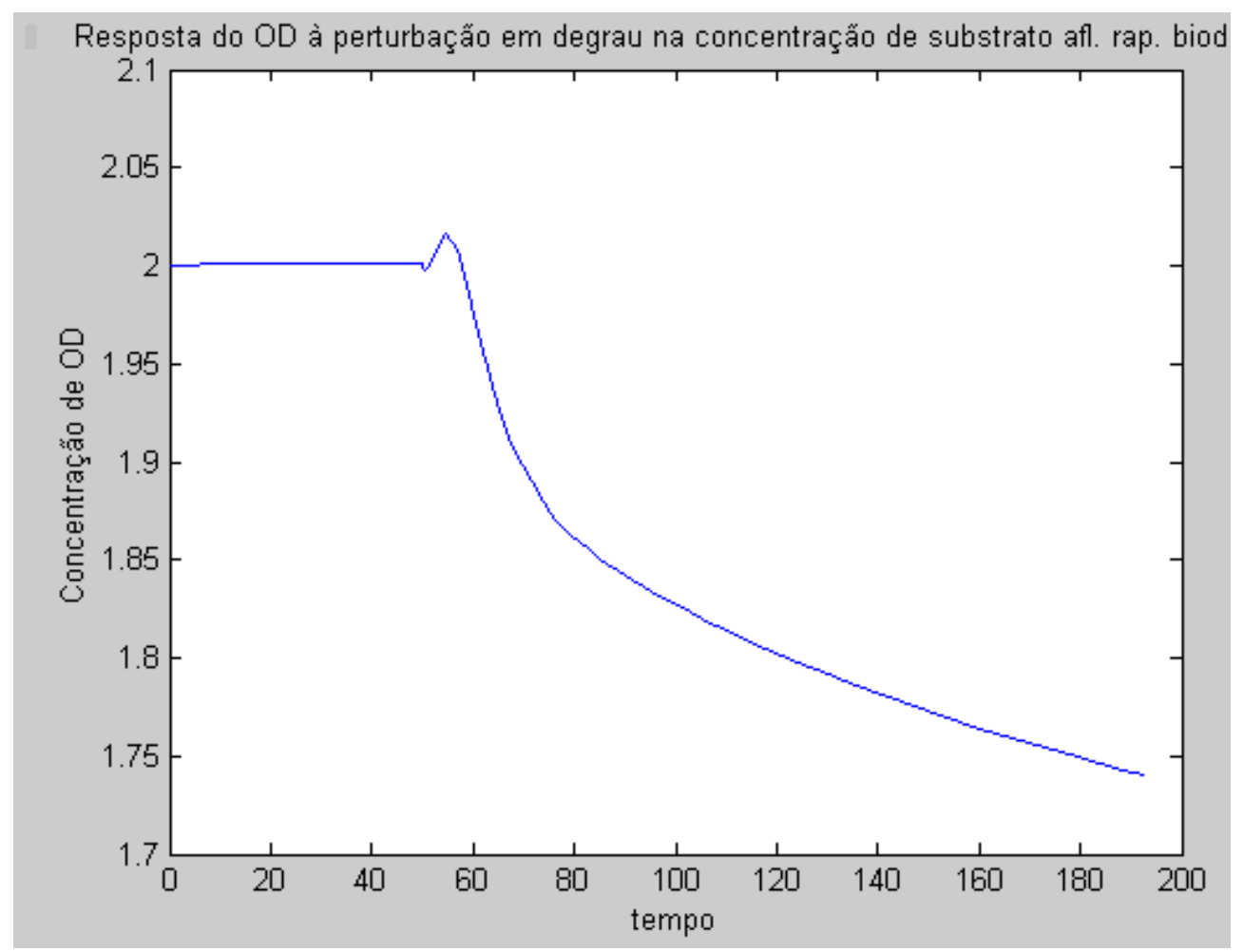

Figura 4.5. Resposta do OD à perturbação em degrau na concentração afluente de $S_{S}$

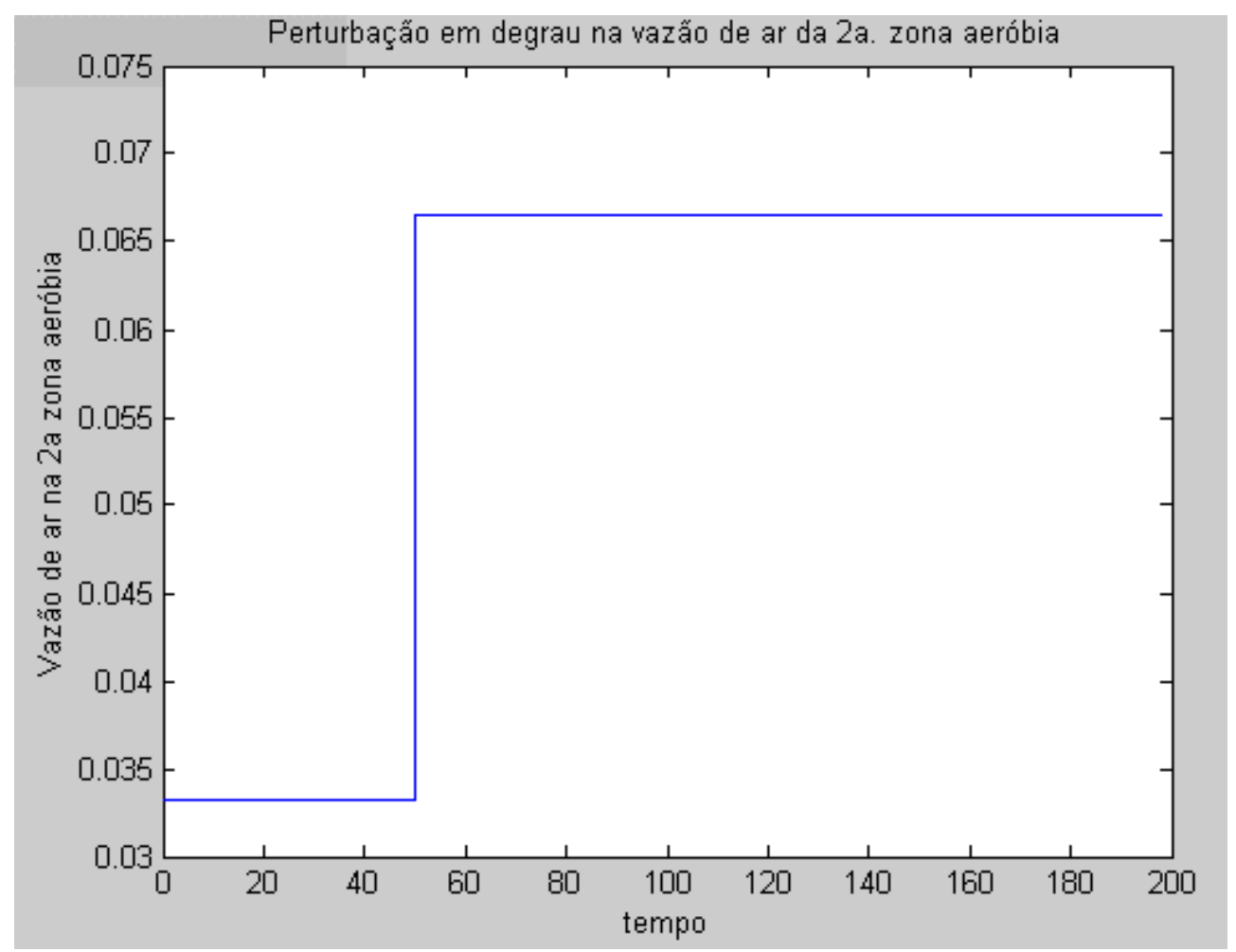

Figura 4.6. Perturbação em degrau na vazão de ar na $2^{\mathrm{a}}$ zona aeróbia 


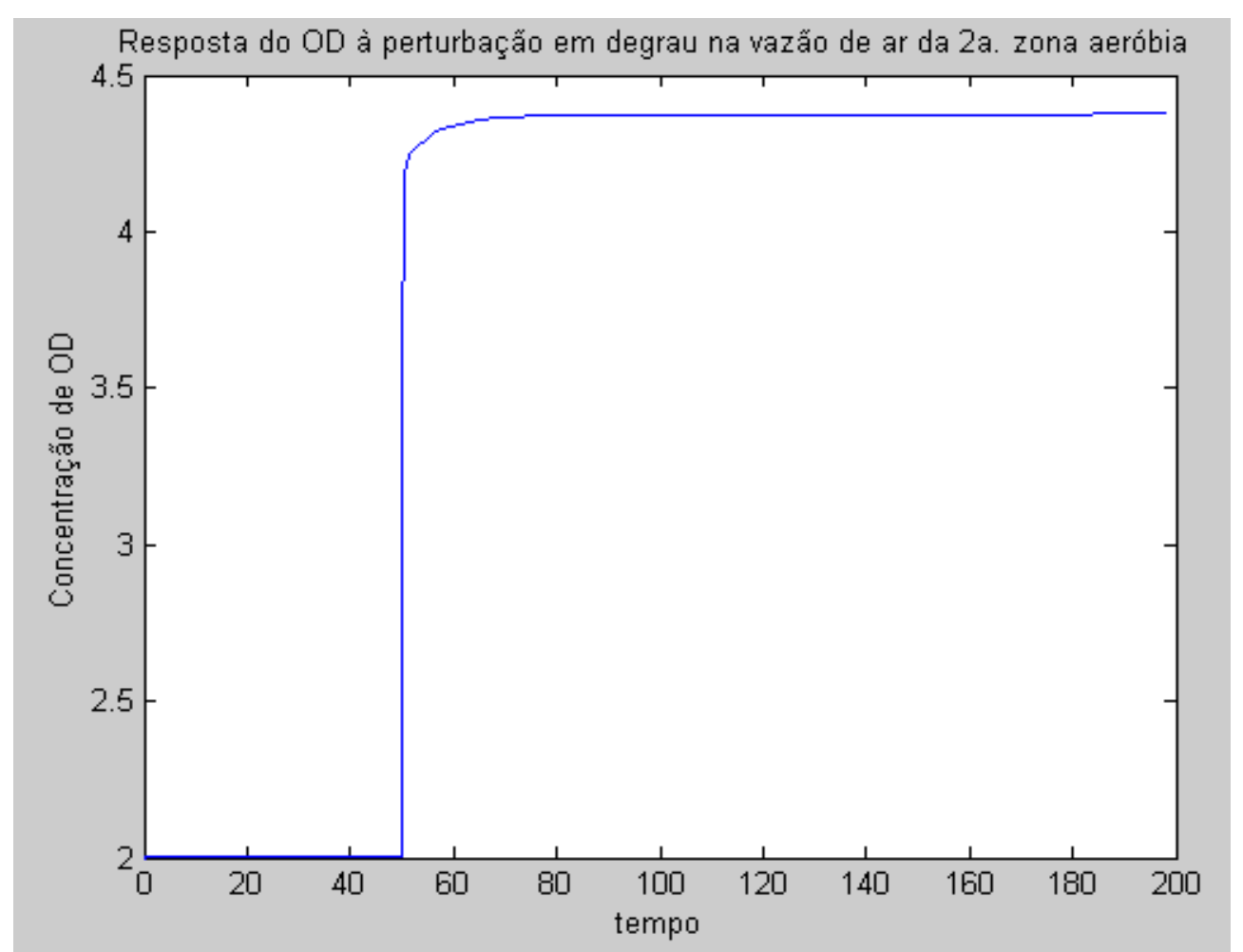

Figura 4.7. Resposta do OD à perturbação em degrau na vazão de ar na $2^{\mathrm{a}}$ zona aeróbia

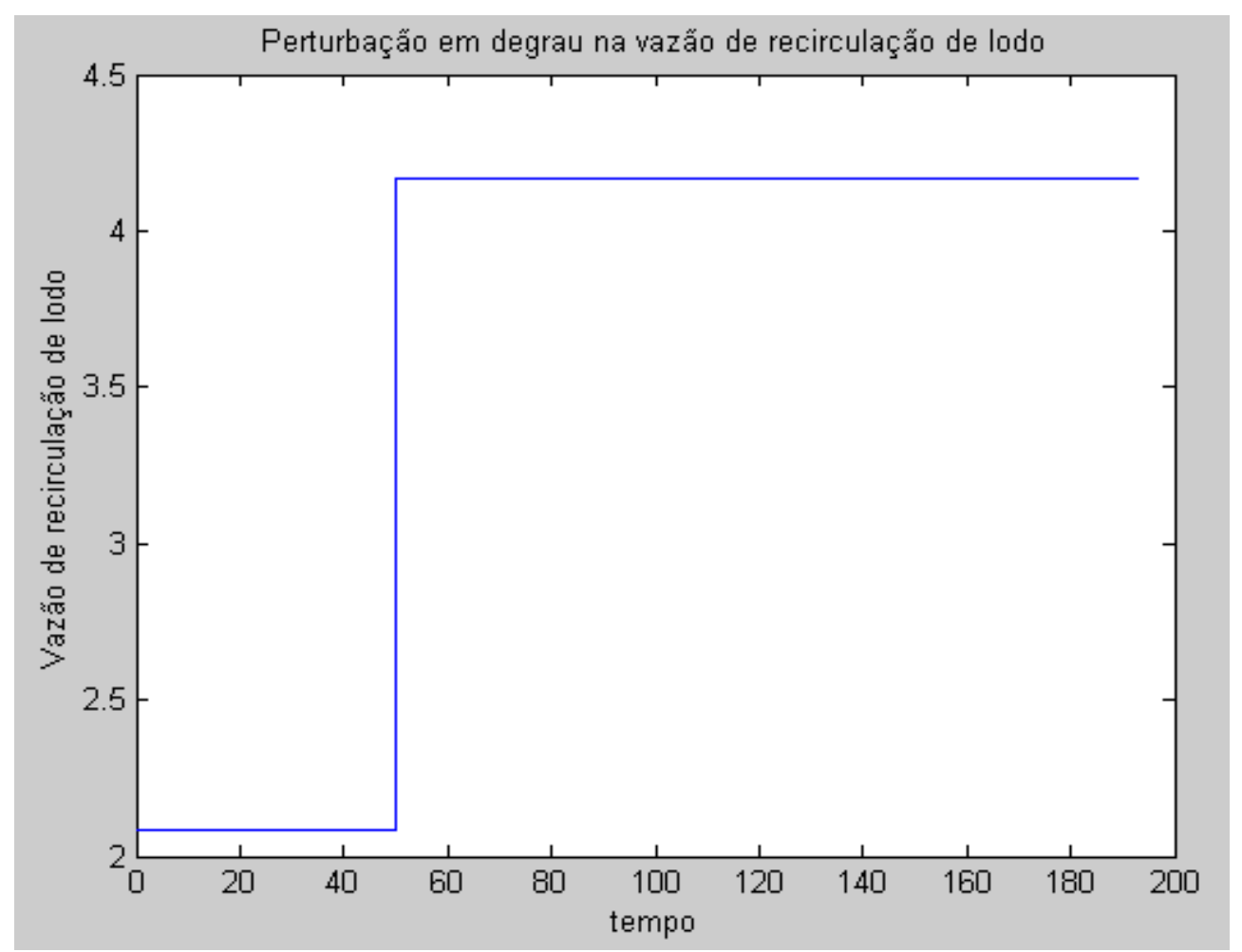

Figura 4.8. Perturbação em degrau na vazão de recirculação de lodo 


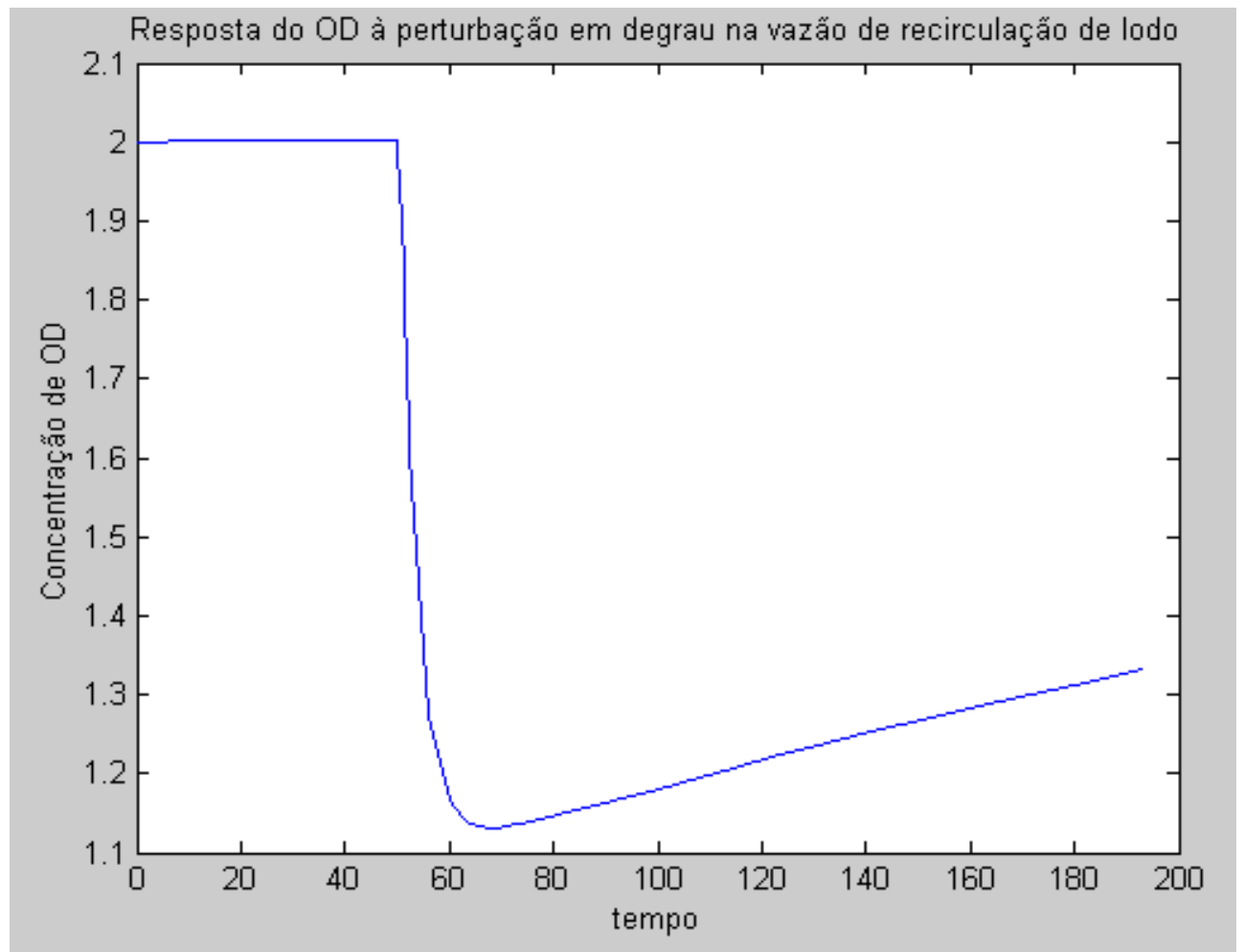

Figura 4.9. Resposta do OD à perturbação em degrau na vazão de recirculação de lodo

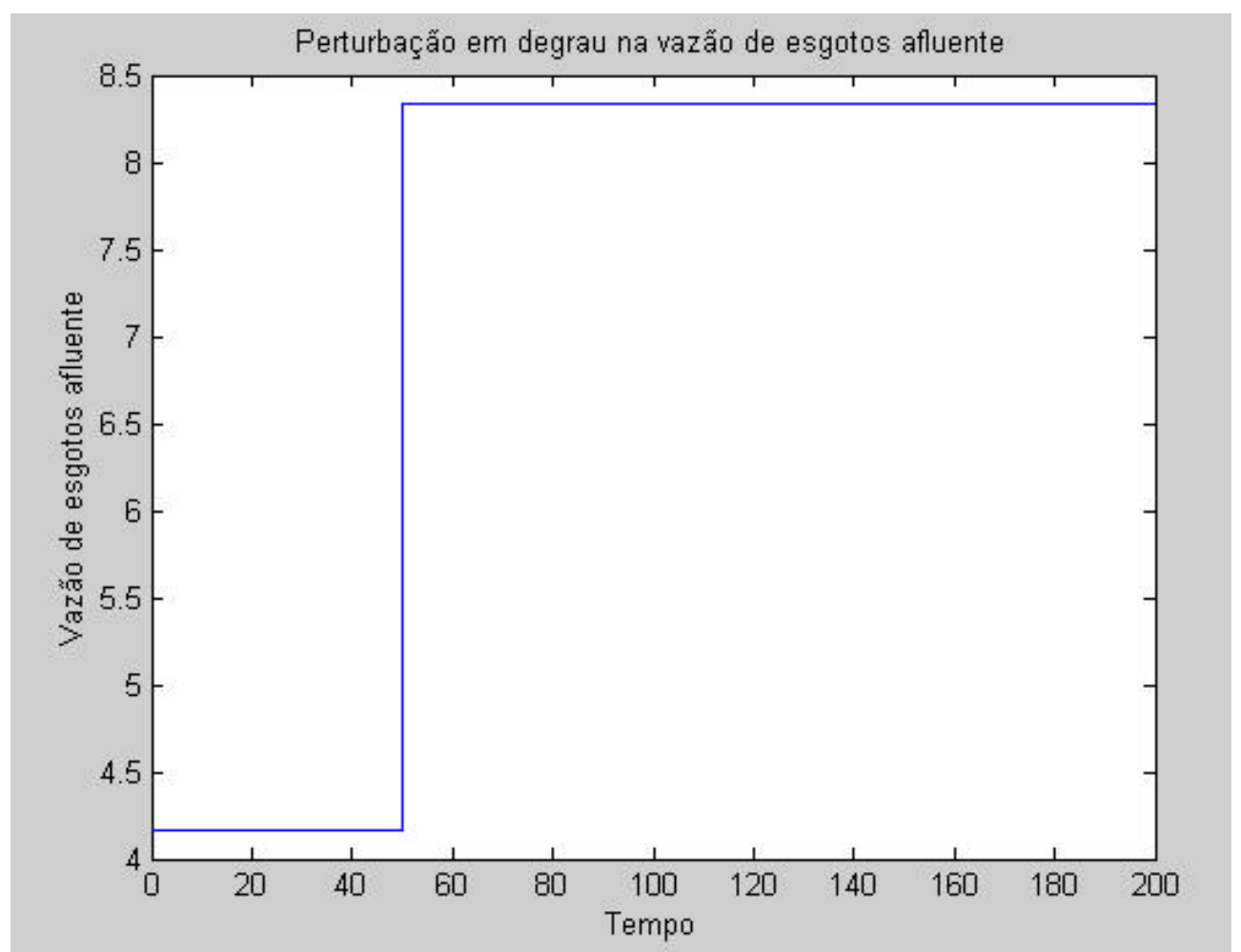

Figura 4.10. Perturbação em degrau na vazão de esgotos afluente 


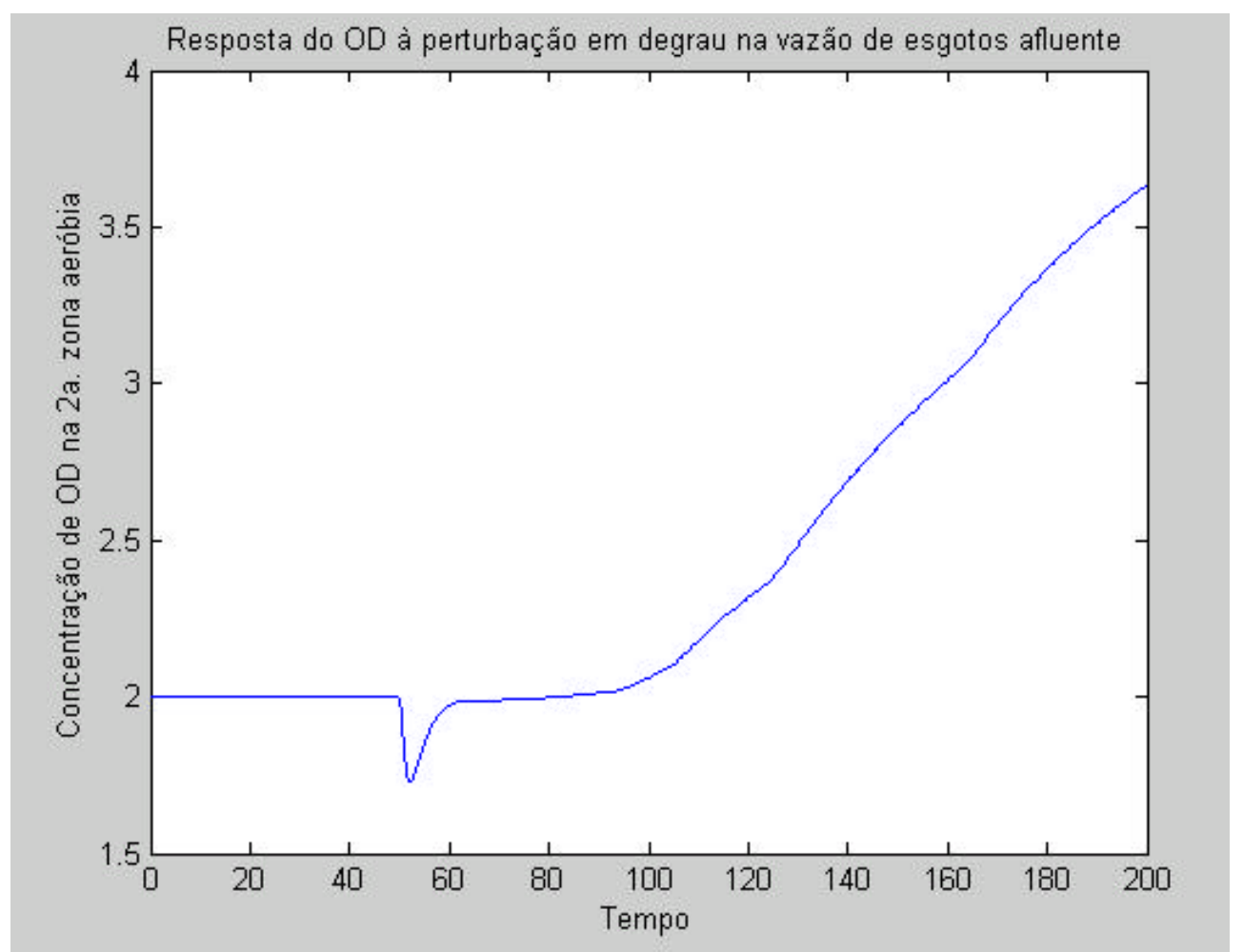

Figura 4.11. Resposta do OD à perturbação em degrau na vazão de esgotos afluente

A ausência de tempo morto pode ser observada nas figuras 4.2 a 4.11 pela resposta imediata da variável de saída a todas variáveis de entradas consideradas. Aguirre (2000) argumenta, entretanto, que tal procedimento só é válido para sistemas com ruído suficientemente baixo nas entradas. O que se propõe, então, é adotar um procedimento para determinação de tempo morto que também valha para sinais com ruído elevado. Tal procedimento consiste no cálculo da função de correlação cruzada (FCC) entra cada uma das entradas e a saída. A entrada será considerada com tempo morto em relação à saída, se a curva de FCC estiver fora de um determinado intervalo de confiança. O intervalo de confiança é a região delimitada da FCC onde esta deve permanecer para ser considerada nula. O cálculo do tempo morto é feito através da localização do instante em que ocorre o máximo da FCC fora do intervalo de confiança. Para a análise do tempo morto nesse trabalho, foi considerado um intervalo de confiança de $95 \%$, sendo seus limites aproximadamente $\pm 1,96 /(N)^{1 / 2}$, onde $\mathrm{N}$ é o tamanho do registro de dados disponíveis. Para o caso das variáveis de entrada adotadas para o modelo a ser construído nesta dissertação, não foi observado tempo morto em nenhuma das variáveis de entrada, conforme figuras 4.12 a 4.16. 


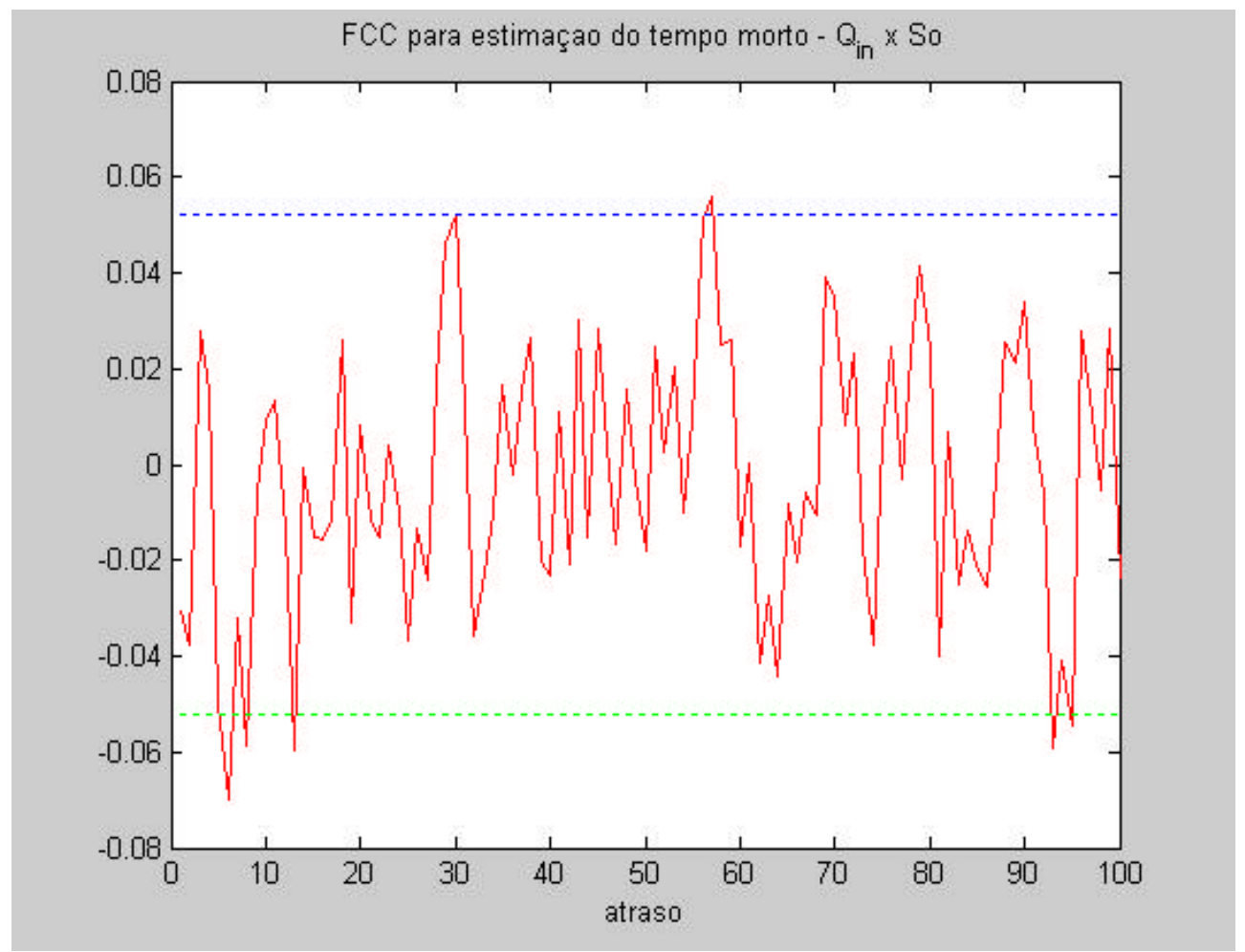

Figura 4.12. Análise de tempo morto de $Q_{i n} \mathrm{x} S_{o}$

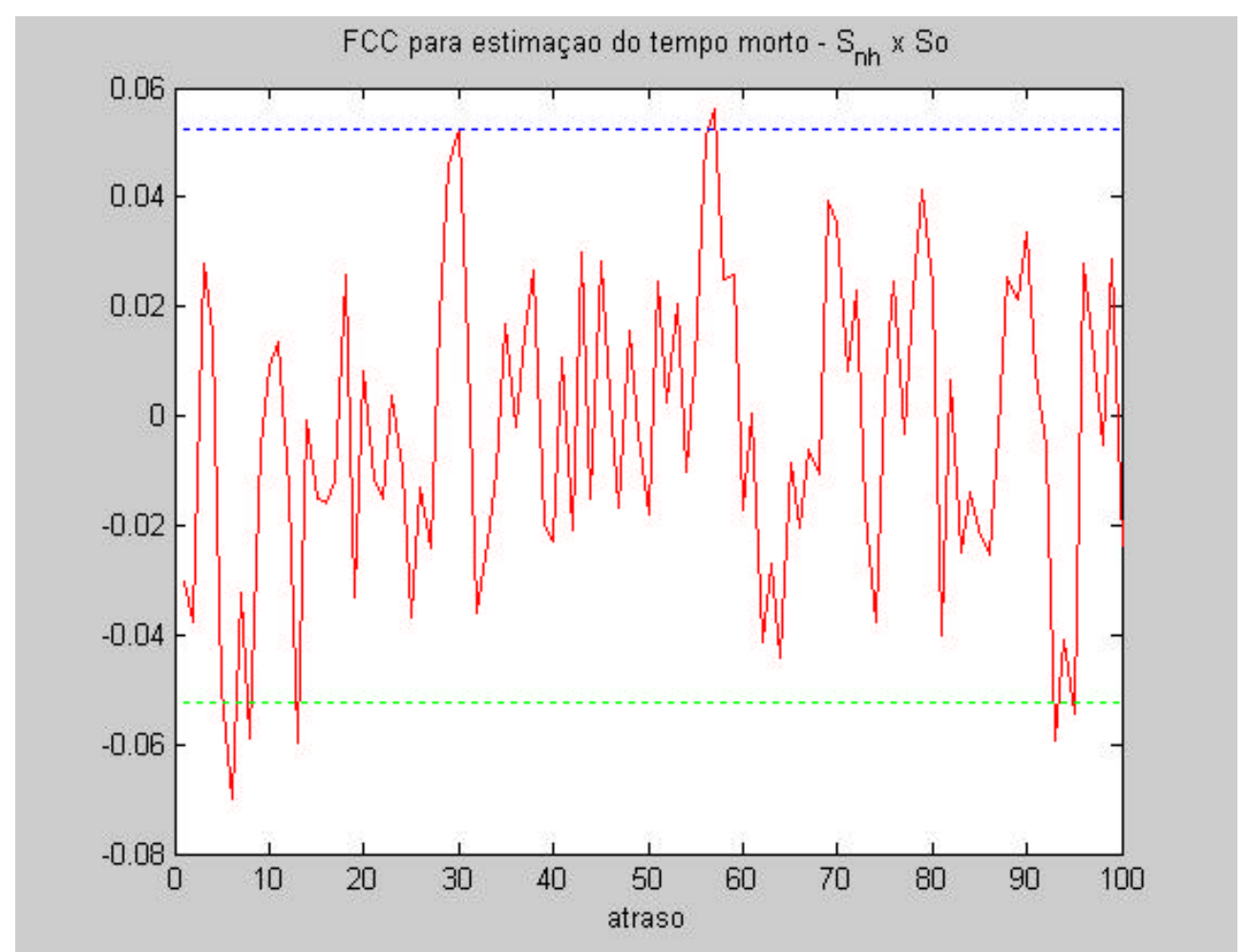

Figura 4.13. Análise de tempo morto de $S_{n h 3} \mathrm{x} S_{o}$ 


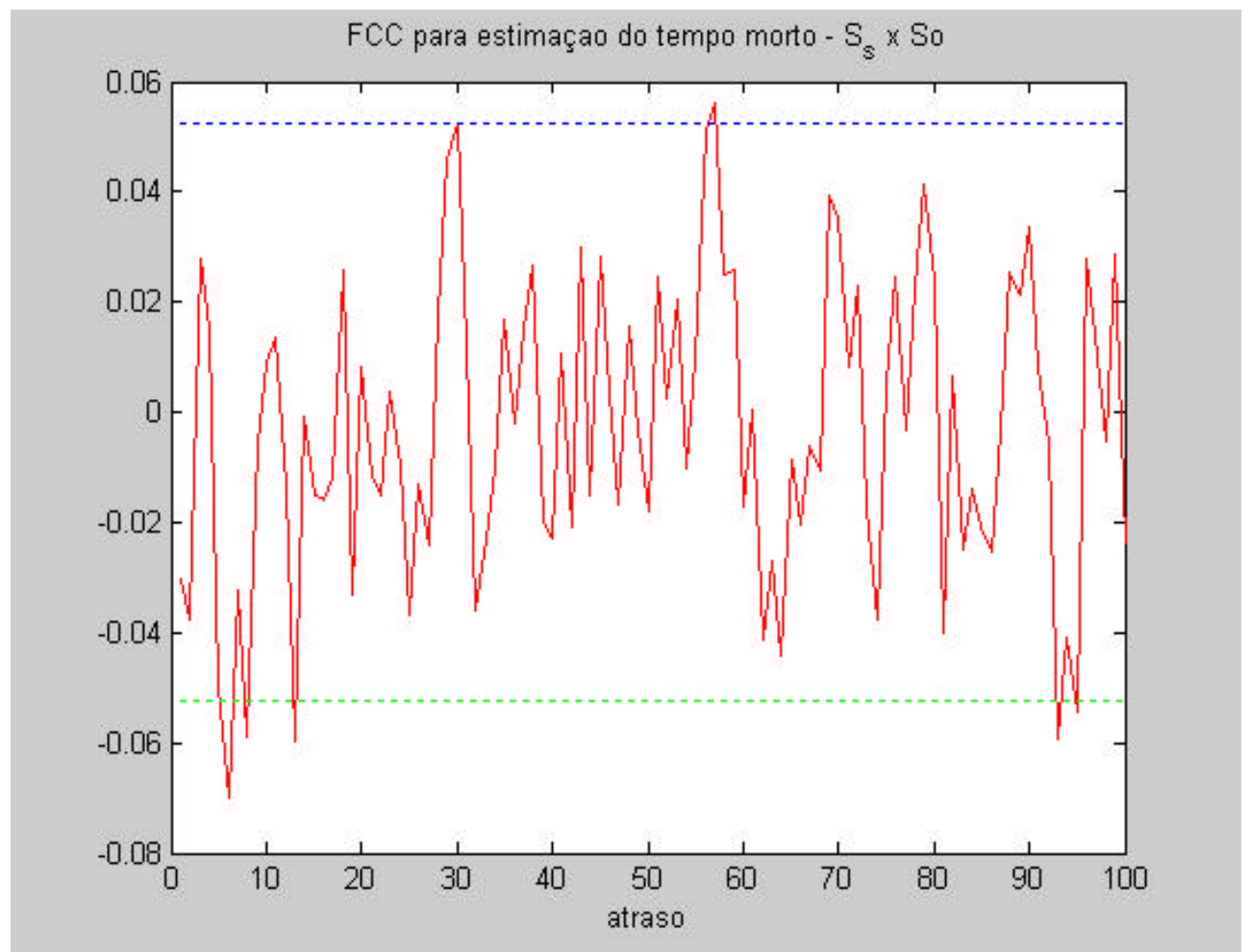

Figura 4.14. Análise de tempo morto de $S_{S} \mathrm{x} S_{o}$

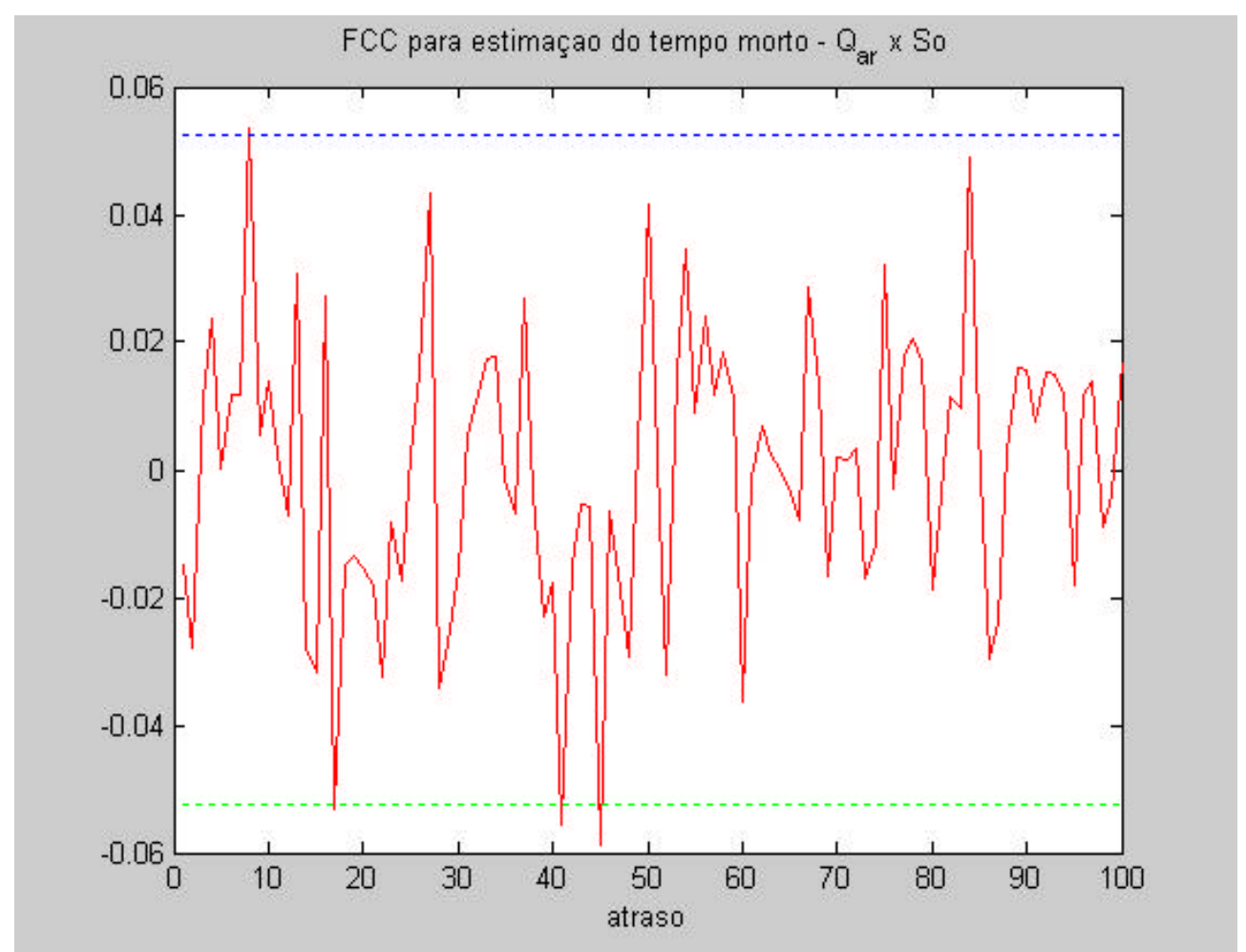

Figura 4.15. Análise de tempo morto de $Q_{a r} \mathrm{x} S_{o}$ 


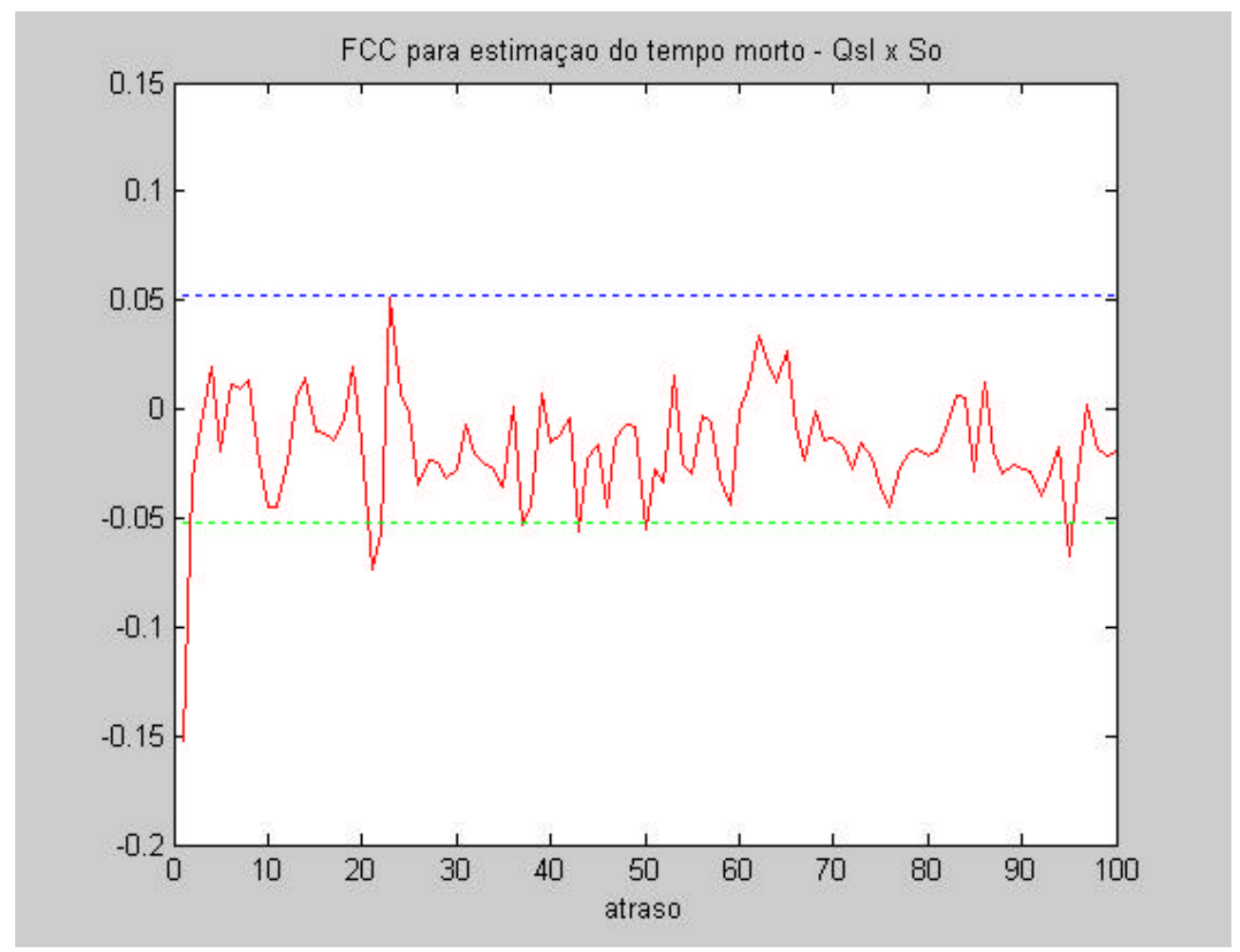

Figura 4.16. Análise de tempo morto de $Q_{s l} \mathrm{X} S_{o}$

\subsubsection{Escolha do tempo de amostragem}

Embora, na prática a freqüência de amostragem seja escolhida entre 5 a 10 vezes a maior freqüência de interesse contida nos dados, a utilização deste critério não é trivial, visto que às vezes esta frequiência não é conhecida de antemão.

Para que se verifique se um sinal está sendo amostrado satisfatoriamente, Aguirre (2000) propôs um critério simples que tem se mostrado eficaz na obtenção de tempos de amostragem em diversas plantas reais. Este critério assume que o sinal de teste $y^{*}(k)$ é obtido com um tempo de amostragem muito pequeno (muito menor que o necessário), portanto estando superamostrado. Dessa forma, $y^{*}(k)$ deve ser decimado, visando a obtenção de $y(k)$ com um tempo de amostragem apropriado, o que é conseguido através da verificação do grau de correlação (redundância) entre observações adjacentes de $y^{*}(k)$. Quanto maior for a correlação entre duas amostras consecutivas, mais superamostrado estará $y^{*}(k)$. 
A medida dos efeitos da superamostragem de $y^{*}(k)$ pode ser calculada por funções de autocovariância, uma linear e outra não linear, conforme as equações 4.1 e 4.2:

$$
\begin{aligned}
& r_{y^{*}}(\tau)=E\left[\left(y^{*}(k)-\overline{y^{*}(k)}\right)\left(y^{*}(k-\hat{\mathrm{o}})-\overline{y^{*}(k)}\right)\right] \\
& r_{y^{* 2^{\prime}}}(\tau)=E\left[\left(y^{* 2}(k)-\overline{y^{* 2}(k)}\right)\left(y^{* 2}(k-\hat{o})-\overline{y^{* 2}(k)}\right)\right]
\end{aligned}
$$

A escolha do tempo de amostragem de $y(k)$ é realizada primeiramente obtendo-se os primeiros mínimos das funções de autocorrelação acima e a partir desses atrasos, determinando-se o valor mínimo. Este mínimo deverá estar entre 10 e 20 (ou 5 e 25 , de modo relaxado).

O tempo de amostragem escolhido para a presente modelagem foi $T_{s}=0,16 \mathrm{~h}$ (de acordo com Sotomayor, 2002), que pode ser verificado com a observação das duas curvas de autocorrelação (figuras 4.17 e 4.18).

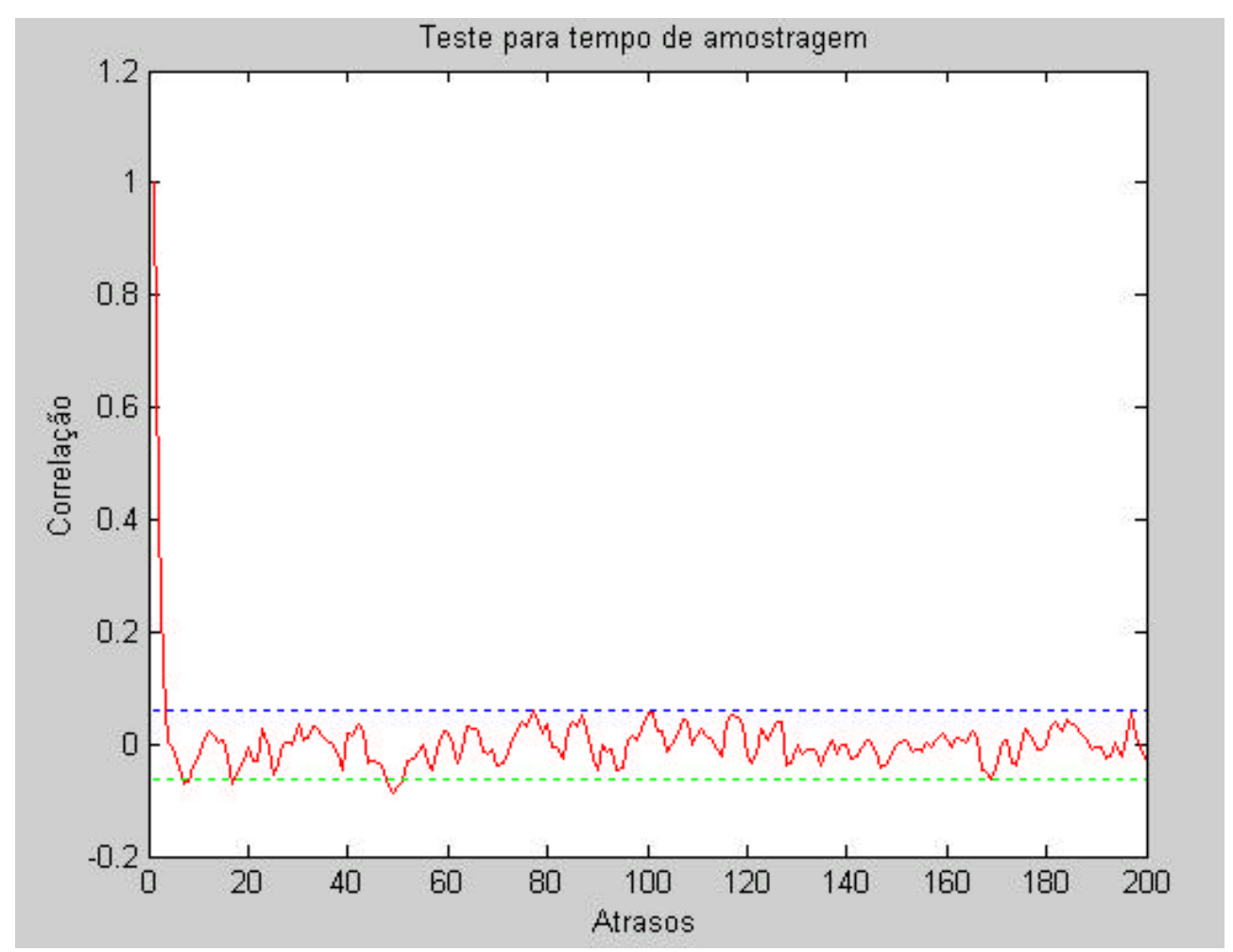

Figura 4.17. Análise de correlação linear 


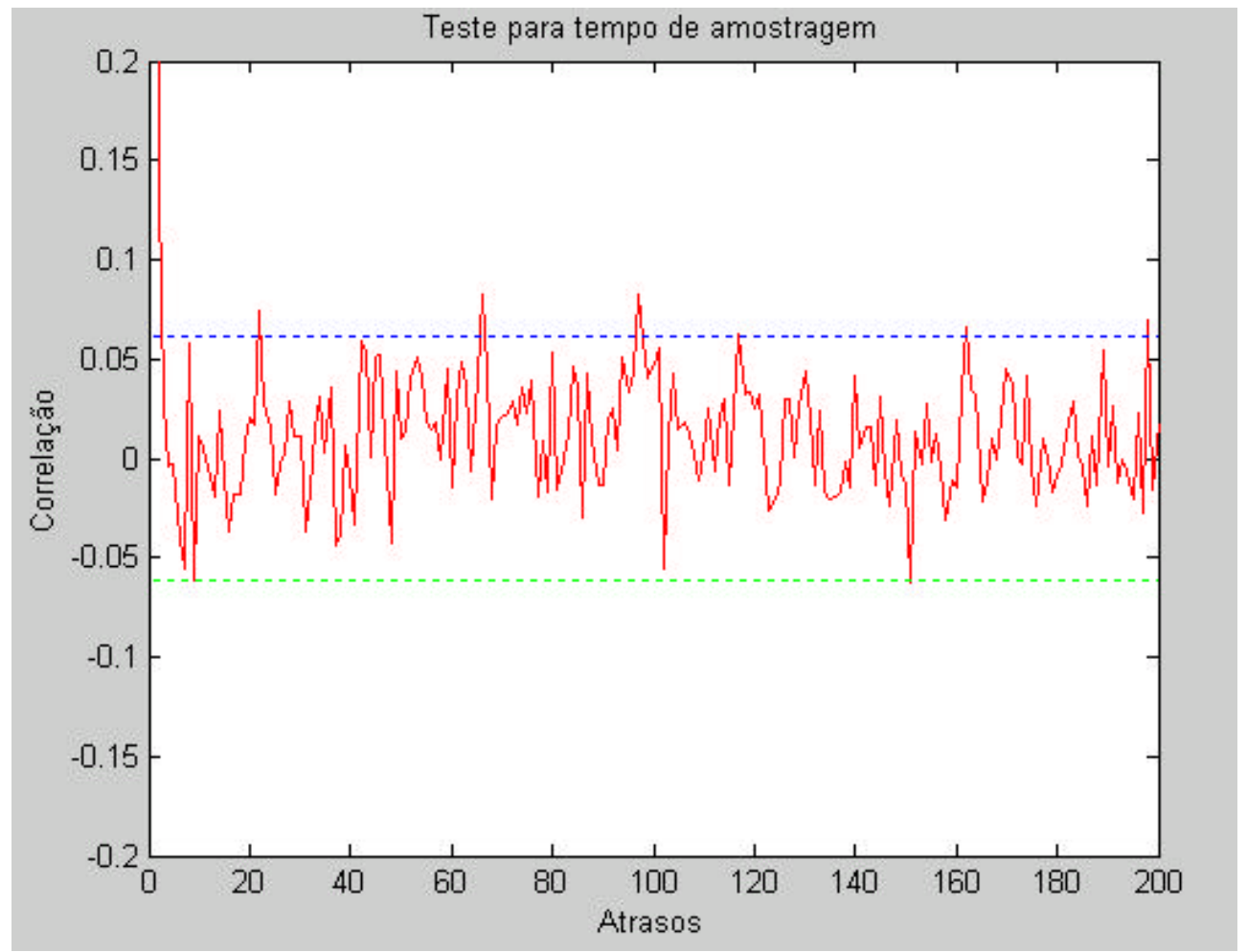

Figura 4.18. Análise de correlação não linear

O atraso observado para a análise de correlação linear para um tempo de amostragem de $0,16 h$ foi igual a 6 períodos de amostragem e o mesmo atraso para a análise de correlação não-linear foi igual a 5 períodos de amostragens. Portanto, segundo Aguirre (2000), pelo critério relaxado, este tempo de amostragem seria adequado à coleta dos sinais de entrada do treinamento do modelo.

\subsubsection{Estrutura do modelo}

O modelo nebuloso será estruturado de modo que a saída será função de seu(s) valor(es) anterior(es) bem como dos valores anteriores da(s) entrada(s). Assim, a configuração do modelo terá a configuração $y(k)=f\left(y\left(k-n_{1}\right) y\left(k-n_{2}\right) \ldots y\left(k-n_{a}\right) u_{1}\left(k-m_{1}\right)\right.$ $\left.u_{1}\left(k-m_{2}\right) \ldots u_{1}\left(k-m_{b}\right) \quad u_{2}\left(k-w_{1}\right) \quad u_{2}\left(k-w_{2}\right) \ldots u_{2}\left(k-w_{c}\right) \quad u_{z}\left(k-x_{1}\right) u_{z}\left(k-x_{2}\right) \ldots u_{z}\left(k-x_{e}\right)\right)$, onde $y$ é a saída, $u_{1}, u_{2}$ e $u_{z}$ são entradas, $n_{1}, n_{2}, \ldots, n_{a}$ são os atrasos da saída $y, m_{1}, m_{2}, \ldots, m_{b}$ são os atrasos da entrada $u_{1}, w_{1}, w_{2}, \ldots, w_{c}$ são os atrasos da entrada $u_{1}$, e $x_{1}, x_{2}, \ldots, x_{e}$ são os atrasos da entrada $u_{z}$. 
Shaw e Simões argumentam que cada entrada deve ter de 3 a 7 funções de pertinência (FPs), para o sistema de inferência nebuloso possuir uma melhor precisão. Assim, para o modelo obtido poderá ter uma quantidade de termos lingüísticos que se aproxime mais da forma de raciocínio humano.

Para este trabalho, propõe-se modelar a concentração de OD da $2^{\mathrm{a}}$ zona aeróbia utilizando-se como variáveis de entrada a concentração de amônia afluente, a vazão de ar na $2^{\text {a }}$ zona aeróbia, a vazão de esgoto afluente, a concentração de substrato rapidamente biodegradável afluente e a vazão de recirculação de lodo. Os demais parâmetros serão considerados constantes.

O sistema de inferência nebuloso construído será do tipo de Takagi-Sugeno (Takagi e Sugeno, 1985). A construção deste modelo utilizará as técnicas de otimização não linear ANFIS (neuro-nebuloso) do toolbox fuzzy do Matlab e a discretização nebulosa com regras limitadas para a obtenção dos parâmetros antecedentes e conseqüentes. A figura 4.19 representa a estrutura do procedimento de coleta dos dados de treinamento.

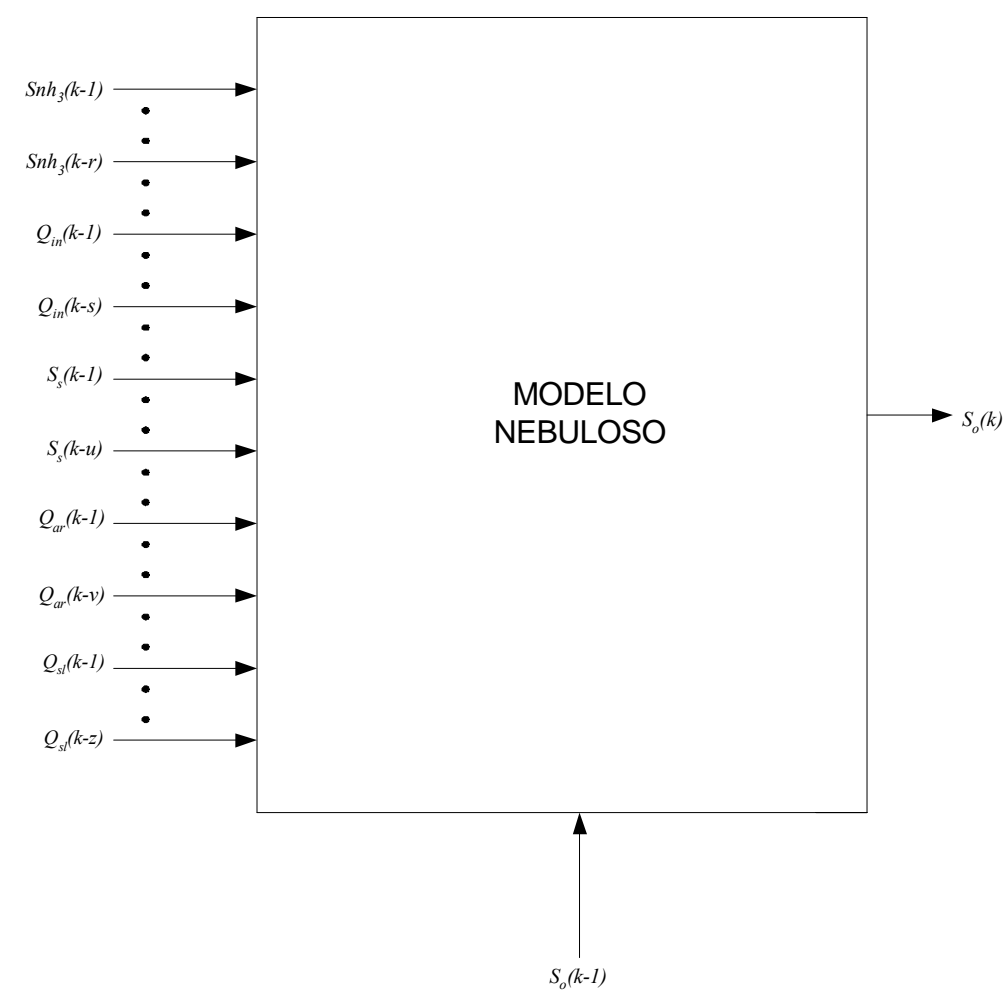

Figura 4.19. Modelo proposto 
onde $S_{n h 3}$ é a concentração de amônia afluente, $Q_{i n}$ é a vazão de esgotos afluente, $S_{s}$ é a concentração de substrato rapidamente biodegradável afluente, $Q_{a r}$ é vazão de ar na $2^{\text {a }}$. zona aeróbia, $Q_{s l}$ é a vazão de recirculação de lodo e $S_{o}$ é a concentração de oxigênio dissolvido na $2^{\mathrm{a}}$. zona aeróbia.

\subsection{Modelagem nebulosa da planta}

Para o desenvolvimento do modelo foram coletados 1400 pontos referentes às entradas e à saída para a geração de um vetor de treinamento. Tais pontos foram gerados a partir de sinais aleatórios aplicados simultaneamente em todas as entradas, coletados a cada tempo de amostragem. As figuras 4.20 a 4.24 mostram uma amostra dos sinais aplicados às entradas que excursionam entre a metade e o dobro dos respectivos valores nominais. Foi escolhido como método de obtenção da função nebulosa inicial a sub-clusterização com funções de pertinência gasussianas e onde o raio de influência foi escolhido de forma que se pudesse observar o comportamento do modelo para particionamentos dos universos de discurso das variáveis de entrada que fossem de 3 a 7 agrupamentos por variável. A escolha da sub-clusterização para a geração do modelo nebuloso inicial se deve à maldição da dimensionalidade ("curse of dimensionality") do método "grid partition" já observada em ensaios realizados durante o desenvolvimento desta dissertação, onde o número de regras de inferência nebulosa aumentava em uma relação exponencial com o aumento de número de regressores das entradas. Esse aumento exponencial de regras acaba por provocar lentidão de processamento e, por muitas vezes, a superação da capacidade de memória do computador utilizado para modelagem. 


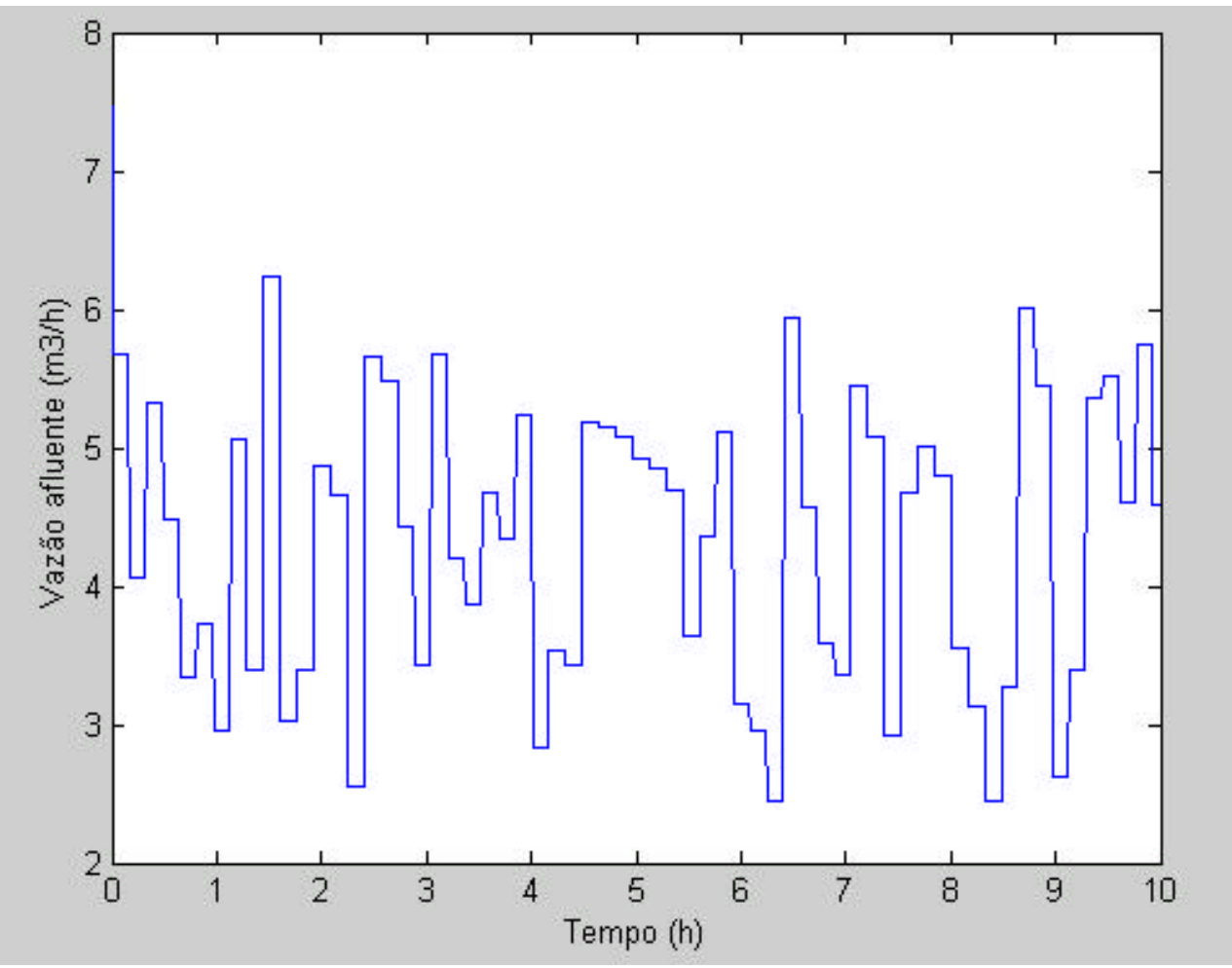

Figura 4.20.Amostra de entrada de vazão de esgotos afluente

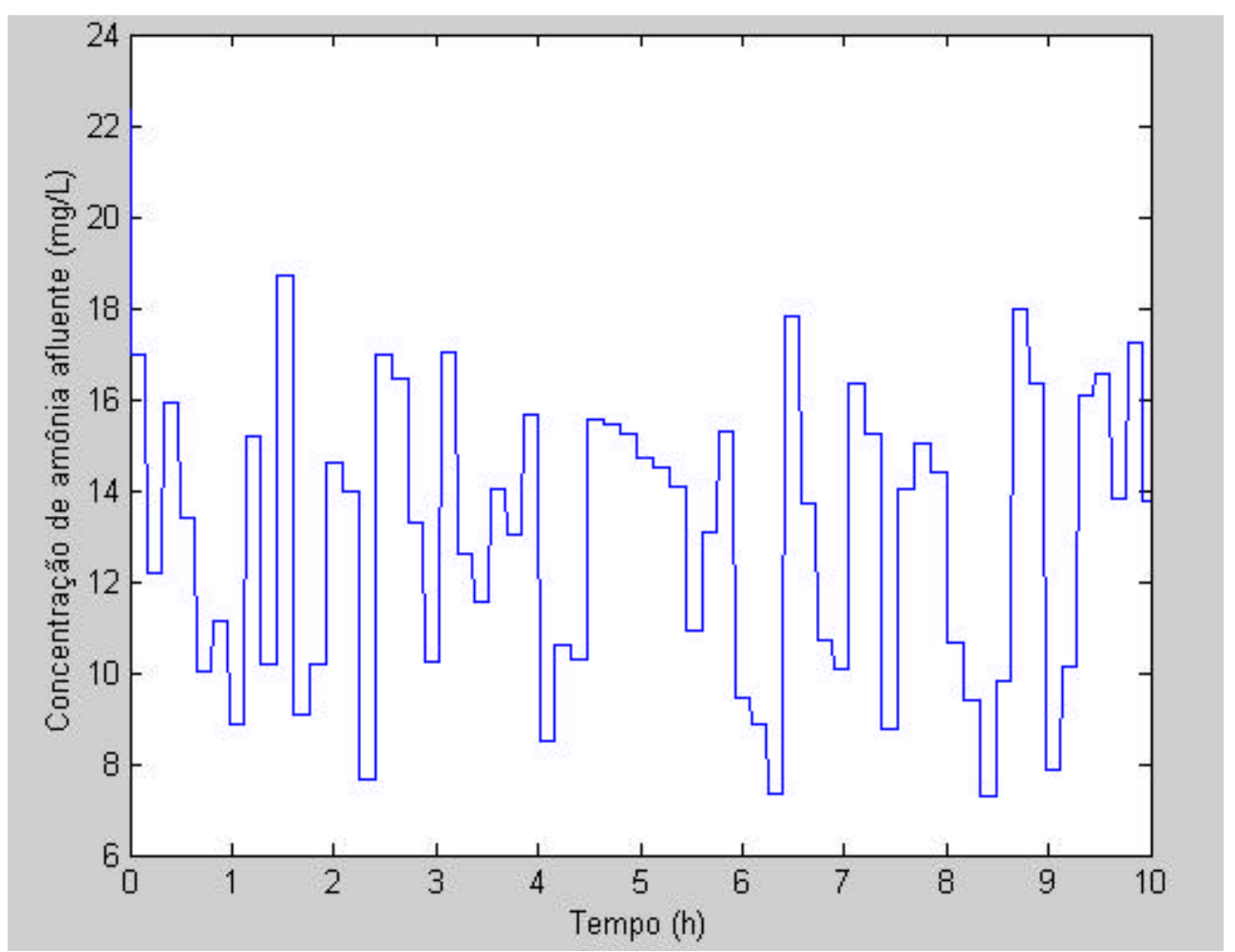

Figura 4.21.Amostra da entrada de concentração de amônia afluente 


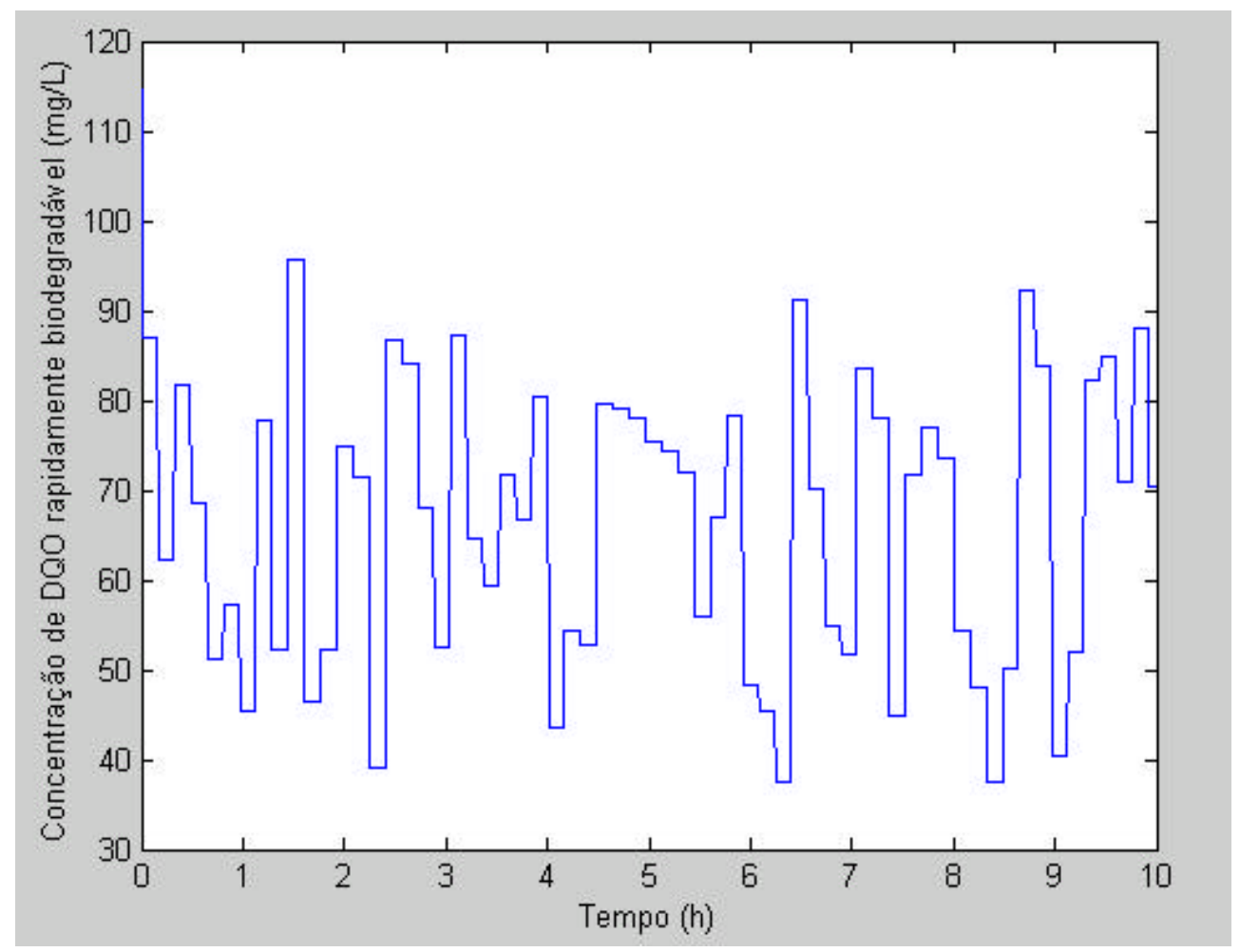

Figura 4.22.Amostra da entrada de DQO rapidamente biodegradável afluente

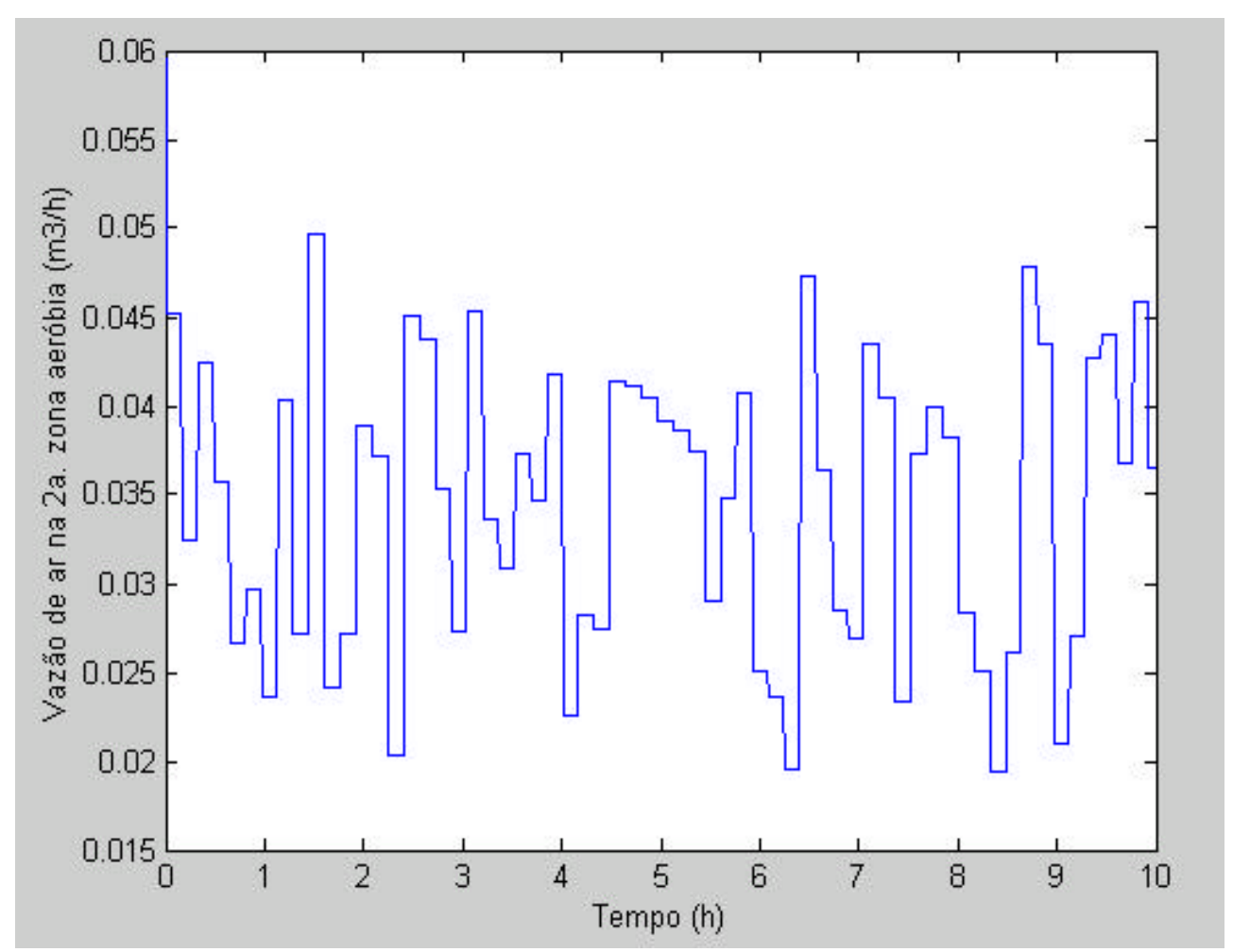

Figura 4.23.Amostra da entrada de vazão de ar na $2^{\mathrm{a}}$.zona aeróbia 


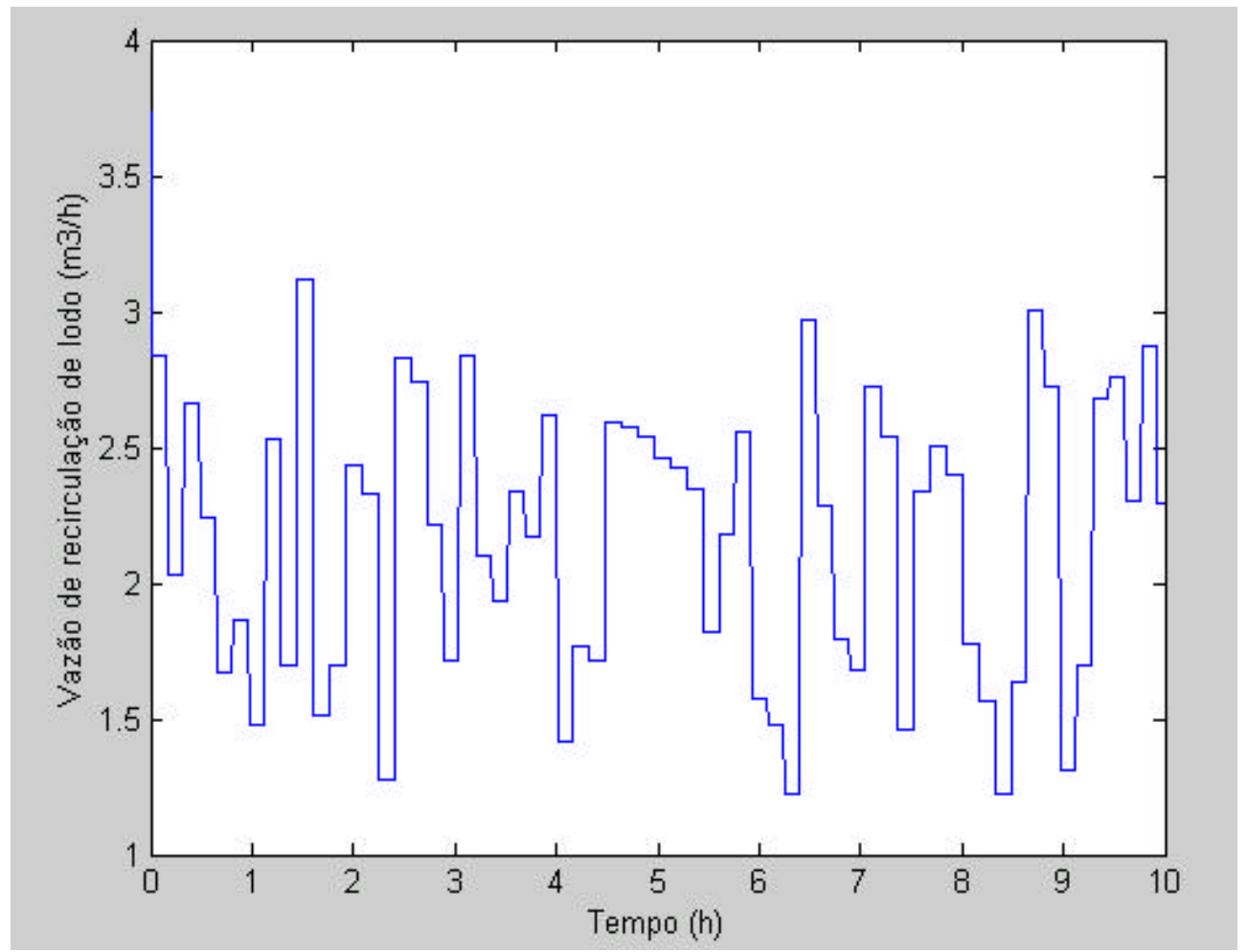

Figura 4.24.Amostra da entrada de vazão de recirculação de lodo

Para a escolha da estrutura, realizou-se um procedimento de busca em que foi estabelecido que uma das entradas seria sempre o regressor do primeiro instante anterior da variável de saída $\left(S_{o}(k-1)\right)$, tendo-se em vista a ausência de tempo morto entre as entradas e a saída bem como pelo fato de ser sujeita a erros que se propagam na validação por simulação livre. O número de regressores das demais entradas foi determinado através de processo de tentativa e erro, observando-se os resultados das respectivas validações. As estruturas (4.3) a (4.6) foram testadas:

- $\quad S_{o}(k)=f\left(S_{n h 3}(k-1), Q_{i n}(k-1), S_{s}(k-1), Q_{a r}(k-1), Q_{s l}(k-1), S_{o}(k-1)\right)$

- $S_{o}(k)=f\left(S_{n h 3}(k-1), S_{n h 3}(k-2), Q_{i n}(k-1), Q_{i n}(k-2), S_{s}(k-1), S_{s}(k-2), Q_{a r}(k-1), Q_{a r}(k-2)\right.$, $\left.Q_{s l}(k-1), Q_{s l}(k-2), S_{o}(k-1)\right)$

- $S_{o}(k)=f\left(S_{n h 3}(k-1), S_{n h 3}(k-2), S_{n h 3}(k-3), Q_{i n}(k-1), Q_{i n}(k-2), Q_{i n}(k-3), S_{s}(k-1), S_{s}(k-2)\right.$, $\left.S_{s}(k-3), Q_{a r}(k-1), Q_{a r}(k-2), Q_{a r}(k-3), Q_{s l}(k-1), Q_{s l}(k-2), Q_{s l}(k-3), S_{o}(k-1)\right)$ 
- $S_{o}(k)=f\left(S_{n h 3}(k-1), S_{n h 3}(k-2), S_{n h 3}(k-3), S_{n h 3}(k-4), Q_{i n}(k-1), Q_{i n}(k-2), Q_{i n}(k-3), Q_{i n}(k-\right.$ 4), $S_{s}(k-1), S_{s}(k-2), S_{s}(k-3), S_{s}(k-4), Q_{a r}(k-1), Q_{a r}(k-2), Q_{a r}(k-3), Q_{a r}(k-4), Q_{s l}(k-1)$, $\left.Q_{s l}(k-2), Q_{s l}(k-3), Q_{s l}(k-4), S_{o}(k-1)\right)$

\subsection{Validação}

Para validação das estruturas de modelo propostas, foram utilizados 1000 pontos de mesmo sinal aleatório em $160 \mathrm{~h}$ de simulação, porém com semente diferente. O método de validação usado foi o de simulação livre em que os termos regressores da saída correspondem a valores estimados nos passos anteriores, conforme mostrado na figura 4.25. Aguirre (2000) observa que validações com preditores um passo à frente geralmente proporcionam resultados exitosos, mesmo para modelos pobres. Nesse sentido, sugere-se uma validação que utilize a saída do próprio modelo e não da planta, para que se inclua em seus cálculos os erros presentes nos valores estimados.

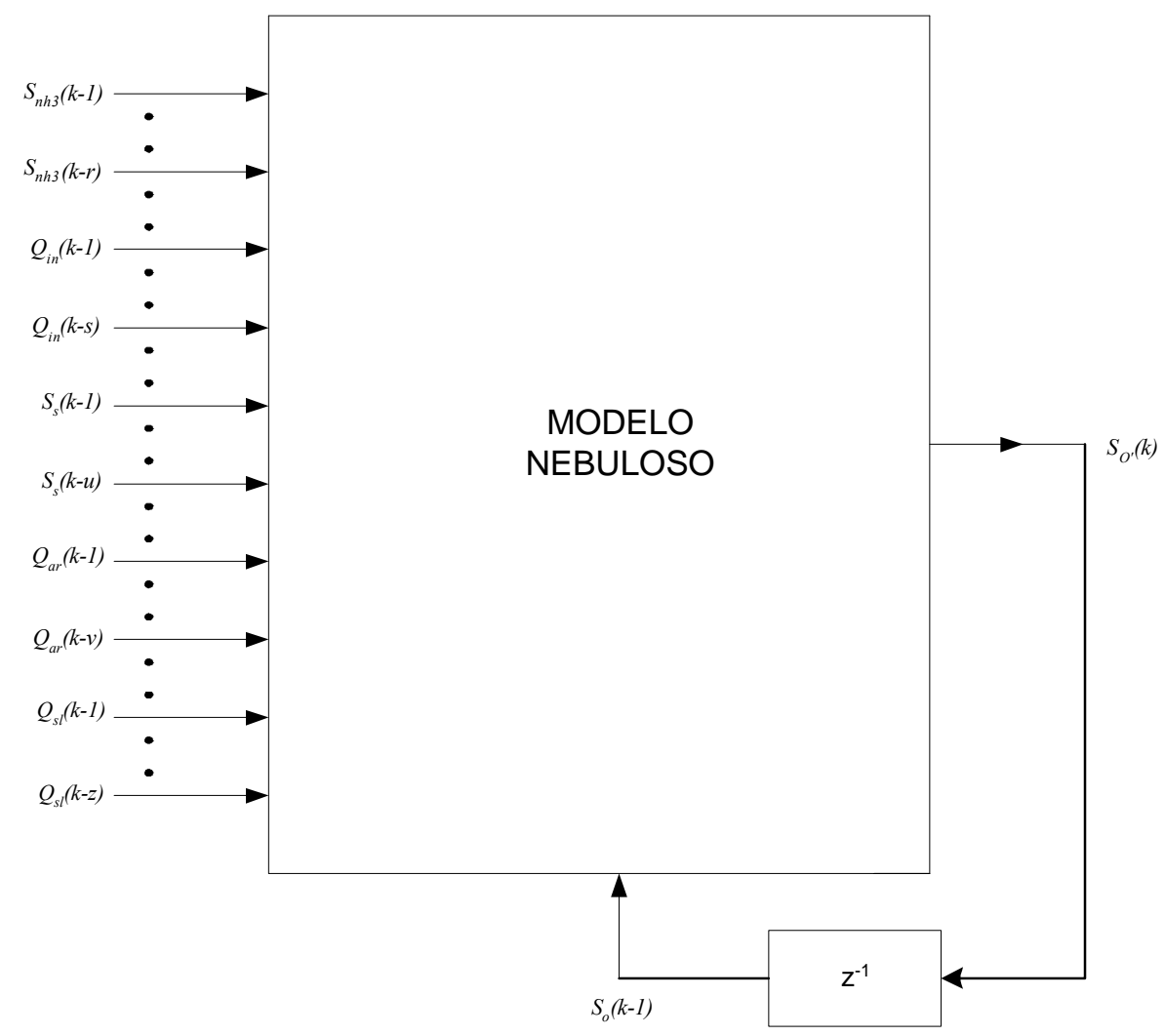

Figura 4.25. Diagrama de Validação do Modelo 
Os experimentos para a verificação dos resultados da modelagem nebulosa do OD constituíram-se de aplicação das entradas do modelo com estruturas de 1, 2, 3 e 4 regressores por variável e dentro dessas estruturas a utilização de 3, 4, 5, 6 e 7 clusters. Os modelos foram treinados por 10 iterações com erro de tolerância de 0,000001. Foram observados o máximo erro de cada modelagem, bem como a respectiva somatória dos erros quadráticos (ISE), conforme tabelas 4.1 a 4.8 .

\begin{tabular}{|c|c|c|c|c|c|}
\hline Modelagem & 3 & 4 & 5 & 6 & 7 \\
& REGRAS & REGRAS & REGRAS & REGRAS & REGRAS \\
\hline ANFIS & 9,3110 & 8,6811 & 8,7421 & 8,2567 & 8,2377 \\
\hline Regras Limitadas & 11,3564 & 14,7833 & 15,0949 & 18,6823 & 18,7920 \\
\hline
\end{tabular}

Tabela 4.1. Comparativo do ISE para 1 Regressor por Variável de Entrada

\begin{tabular}{|c|c|c|c|c|c|}
\hline Modelagem & 3 & 4 & 5 & 6 & 7 \\
& REGRAS & REGRAS & REGRAS & REGRAS & REGRAS \\
\hline ANFIS & 9,9980 & 9,3692 & 9,0191 & 9,9550 & 8,4307 \\
\hline Regras Limitadas & 11,7730 & 14,9940 & 14,7391 & 18,1686 & 18,0509 \\
\hline
\end{tabular}

Tabela 4.2. Comparativo do ISE para 2 Regressores por Variável de Entrada

\begin{tabular}{|c|c|c|c|c|c|}
\hline Modelagem & 3 & 4 & 5 & 6 & 7 \\
& REGRAS & REGRAS & REGRAS & REGRAS & REGRAS \\
\hline ANFIS & 10,8430 & 10,4756 & 9,4337 & 10,6610 & 10,2845 \\
\hline Regras Limitadas & 12,6350 & 15,6437 & 14,8439 & 18,0401 & 17,7414 \\
\hline
\end{tabular}

Tabela 4.3. Comparativo do ISE para 3 Regressores por Variável de Entrada 


\begin{tabular}{|c|c|c|c|c|c|}
\hline Modelagem & 3 & 4 & 5 & 6 & 7 \\
& REGRAS & REGRAS & REGRAS & REGRAS & REGRAS \\
\hline ANFIS & 12,1214 & 10,9506 & 10,8141 & 10,4738 & 11,4194 \\
\hline Regras Limitadas & 13,9673 & 16,7621 & 15,4590 & 18,3972 & 17,9362 \\
\hline
\end{tabular}

Tabela 4.4. Comparativo do ISE para 4 Regressores por Variável de Entrada

\begin{tabular}{|c|c|c|c|c|c|}
\hline Modelagem & 3 & 4 & 5 & 6 & 7 \\
& REGRAS & REGRAS & REGRAS & REGRAS & REGRAS \\
\hline ANFIS & 0,3063 & 0,3137 & 0,3207 & 0,3364 & 0,2839 \\
\hline Regras Limitadas & 0,3634 & 0,4307 & 0,4518 & 0,4801 & 0,4509 \\
\hline
\end{tabular}

Tabela 4.5. Comparativo do erro máximo para 1 Regressor por Variável de Entrada

\begin{tabular}{|c|c|c|c|c|c|}
\hline Modelagem & 3 & 4 & 5 & 6 & 7 \\
& REGRAS & REGRAS & REGRAS & REGRAS & REGRAS \\
\hline ANFIS & 0,2909 & 0,3167 & 0,3174 & 0,4249 & 0,2873 \\
\hline Regras Limitadas & 0,3795 & 0,4456 & 0,4589 & 0,4926 & 0,4625 \\
\hline
\end{tabular}

Tabela 4.6. Comparativo do erro máximo para 2 Regressores por Variável de Entrada

\begin{tabular}{|c|c|c|c|c|c|}
\hline Modelagem & 3 & 4 & 5 & 6 & 7 \\
& REGRAS & REGRAS & REGRAS & REGRAS & REGRAS \\
\hline ANFIS & 0,3168 & 0,3268 & 0,3654 & 0,4484 & 0,4020 \\
\hline Regras Limitadas & 0,3975 & 0,4622 & 0,4689 & 0,5079 & 0,4729 \\
\hline
\end{tabular}

Tabela 4.7. Comparativo do erro máximo para 3 Regressores por Variável de Entrada 


\begin{tabular}{|c|c|c|c|c|c|}
\hline Modelagem & 3 & 4 & 5 & 6 & 7 \\
& REGRAS & REGRAS & REGRAS & REGRAS & REGRAS \\
\hline ANFIS & 0,3440 & 0,3507 & 0,4015 & 0,4431 & 0,4317 \\
\hline Regras Limitadas & 0,4166 & 0,4831 & 0,4803 & 0,5246 & 0,4876 \\
\hline
\end{tabular}

Tabela 4.8. Comparativo do erro máximo para 4 Regressores por Variável de Entrada

Os modelos nebulosos obtidos podem ser construídos através da utilização dos parâmetros otimizados disponíveis nos arquivos com terminação ".fis" do toolbox fuzzy do Matlab. As tabelas 4.9 a 4.11 mostram os parâmetros obtidos com a modelagem nebulosa com uma estrutura de 1 regressor por variável e 3 funções de pertinência (FP) por variável usando o ANFIS e 3 clusters usando a técnica de discretização nebulosa com regras limitadas.

\begin{tabular}{|c|c|c|c|c|c|c|}
\hline FP & $S_{n h 3}(k-1)$ & $Q_{i n}(k-1)$ & $S_{s}(k-1)$ & $Q_{a r}(k-1)$ & $Q_{s l}(k-1)$ & $S_{o}(k-1)$ \\
\hline 1 & {$[3,530$} & {$[1,178$} & {$[18,070$} & {$[0,013$} & {$[0,589$} & {$[0,752$} \\
& $12,350]$ & $4,119]$ & $63,210]$ & $0,022]$ & $2,059]$ & $1,823]$ \\
\hline 2 & {$[3,530$} & {$[1,178$} & {$[18,100$} & {$[-0,010$} & {$[0,589$} & {$[0,752$} \\
& $16,400]$ & $5,477]$ & $83,500]$ & $0,041]$ & $2,740]$ & $2,460]$ \\
\hline 3 & {$[3,530$} & {$[1,178$} & {$[18,100$} & {$[0,069$} & {$[0,589$} & {$[0,752$} \\
& $8,650]$ & $2,890]$ & $44,500]$ & $0,012]$ & $1,450]$ & $1,160]$ \\
\hline
\end{tabular}

Tabela 4.9. Parâmetros antecedentes para 1 Regressor por Variável de Entrada/ANFIS

Os parâmetros antecedentes da função gaussiana são o valor da variável em sua extremidade inicial bem como seu valor para um grau de pertinência igual a 1 . 


\begin{tabular}{|c|c|c|c|c|c|c|c|}
\hline Modelagem & $S_{n h 3}(k-1)$ & $Q_{\text {in }}(k-1)$ & $S_{s}(k-1)$ & $Q_{a r}(k-1)$ & $Q_{s l}(k-1)$ & $S_{o}(k-1)$ & $c t e$ \\
\hline & $-0,01729$ & $-0,007041$ & 0,005935 & 0,006593 & 0,022150 & 0,943200 & $-0,075540$ \\
\cline { 2 - 8 } & $-1,859000$ & $-0,753100$ & 0,339200 & 0,687900 & 2,30200 & 0,939200 & $-0,027270$ \\
\cline { 2 - 9 } & 0,000670 & 0,000223 & 0,003431 & 1,763 e-6 & 0,000112 & 0,920500 & $-0,088390$ \\
\hline \multirow{2}{*}{$\begin{array}{c}\text { RNFIS } \\
\text { Limitadas }\end{array}$} & 0,7584 & 0,9194 & $-0,2369$ & 0,9994 & 0,9547 & 0,9317 & $-0,0723$ \\
\cline { 2 - 9 } & 0,7582 & 0,9193 & $-0,2380$ & 0,9994 & 0,9597 & 0,9440 & $-0,0093$ \\
\cline { 2 - 8 } & 0,7581 & 0,9193 & $-0,2386$ & 0,9994 & 0,9597 & 0,9413 & 0,0735 \\
\hline
\end{tabular}

Tabela 4.10. Comparativo dos parâmetros conseqüentes para 1 Regressor por variável de entrada

\begin{tabular}{|c|c|c|c|c|c|c|}
\hline $\begin{array}{c}\text { Número } \\
\text { de } \\
\text { Clusters }\end{array}$ & $S_{n h 3}(k-1)$ & $Q_{i n}(k-1)$ & $S_{s}(k-1)$ & $Q_{a r}(k-1)$ & $Q_{s l}(k-1)$ & $S_{o}(k-1)$ \\
\hline 1 & 8,4057 & 2,8042 & 43,03730 & 0,0224 & 1,4021 & 1,1581 \\
\hline 2 & 12,6876 & 4,2326 & 64,9607 & 0,0338 & 2,1163 & 1,8947 \\
\hline 3 & 16,9245 & 5,6460 & 86,6534 & 0,0450 & 2,8230 & 2,5079 \\
\hline
\end{tabular}

Tabela 4.11. Centros de clusters da técnica de regras limitadas para 1 Regressor por variável de entrada .

Na figura 4.26 pode-se observar o gráfico de validação do modelo ANFIS para 1 regressor e 3 funções de pertinência por variável. A figura 4.27 apresenta três saídas: a do modelo ANFIS, a do modelo de discretização nebulosa com regras limitadas e a saída do processo validado. 


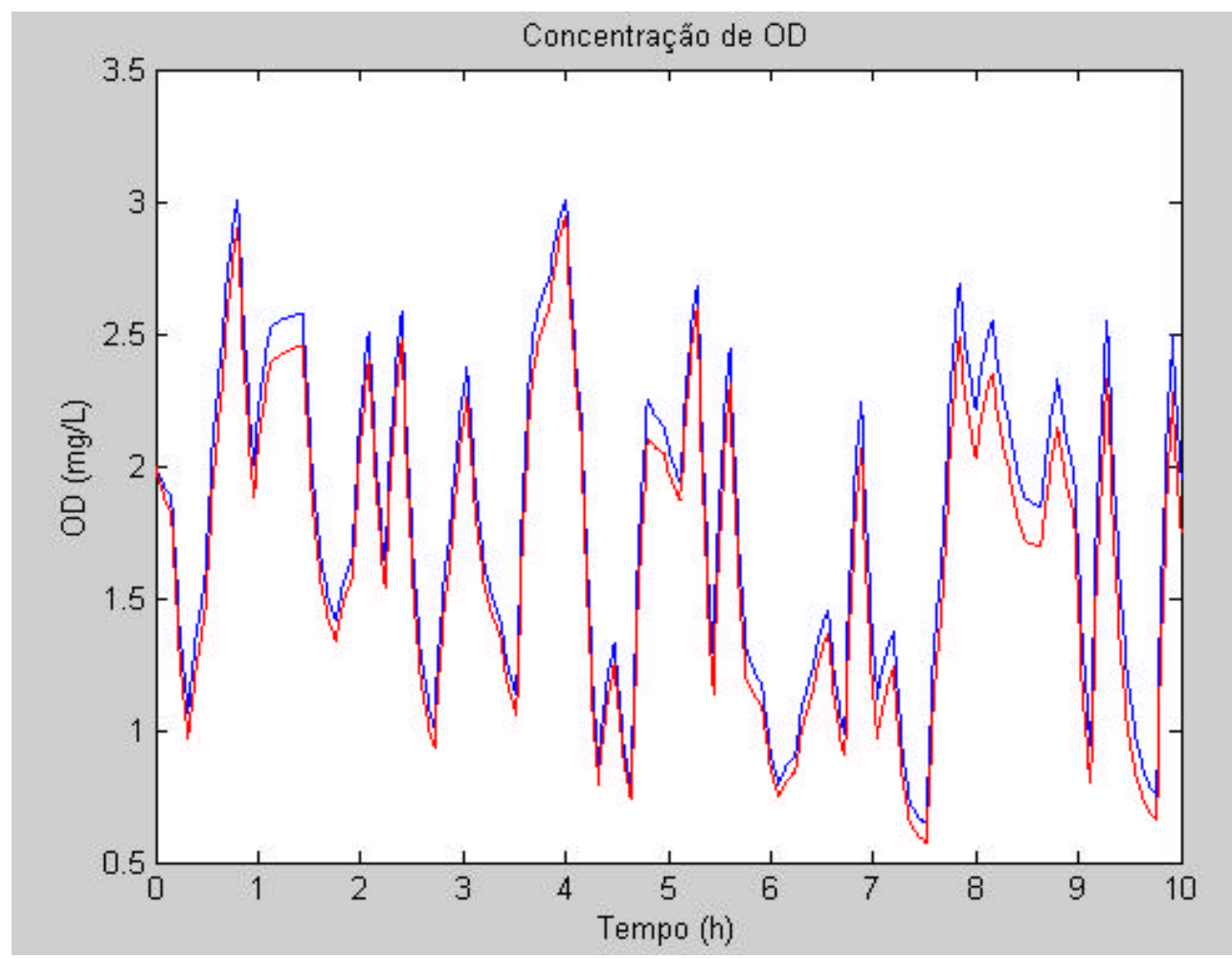

Figura 4.26. Saída de Validação do Modelo ANFIS para 1 Regressor por variável de entrada

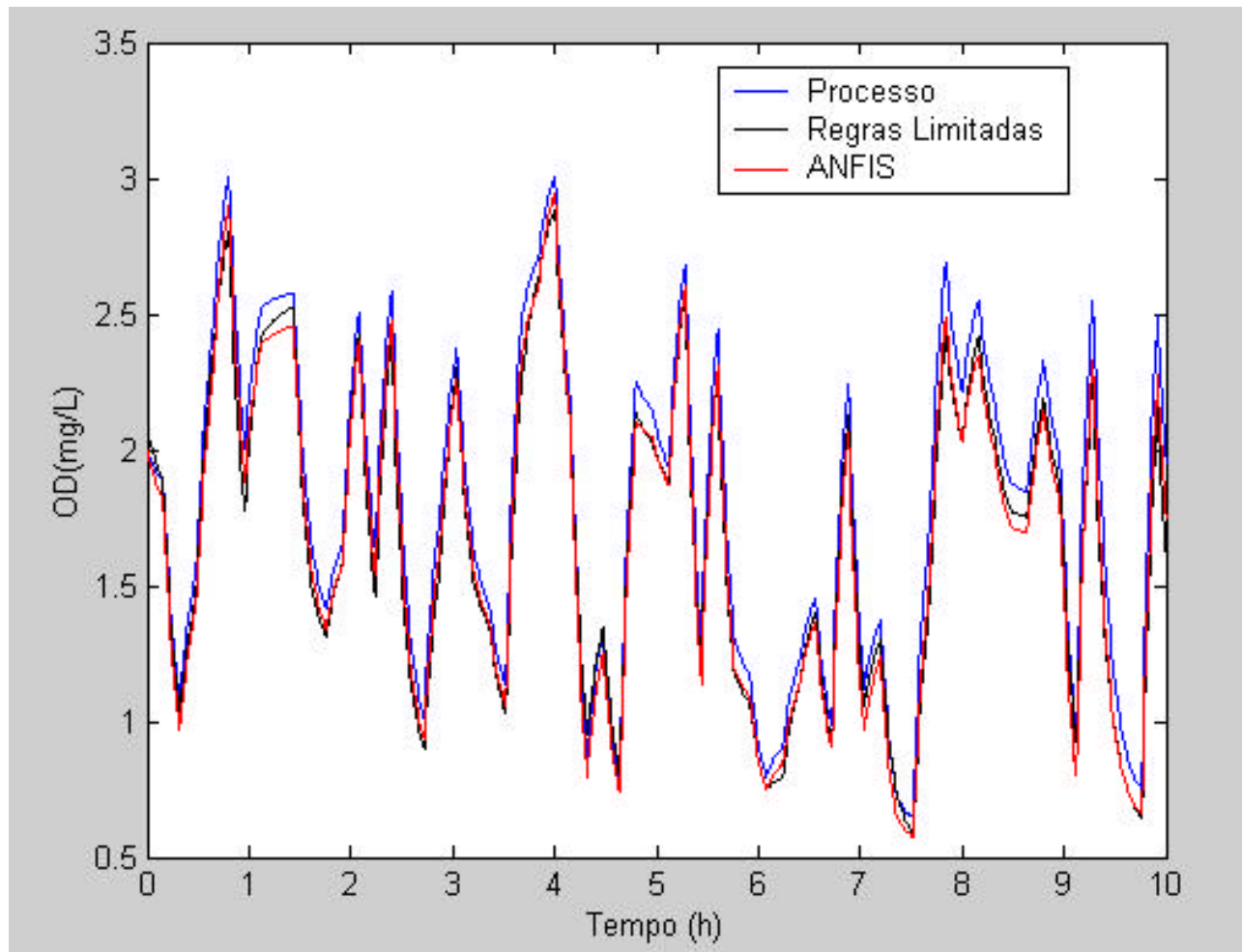

Figura 4.27.Comparativo da saída de validação dos modelos com o processo para 1 Regressor por variável de entrada 


\section{Capítulo 5. \\ Conclusões e perspectivas de trabalhos futuros}

\subsection{Conclusões}

Os modelos existentes de plantas de tratamento de esgotos por lodos ativados, convertidos em sua maioria em simuladores, têm sido baseados em equações fenomenológicas de comportamento acentuadamente não-linear. A parametrização de tais modelos não tem se mostrado amigável aos operadores de tais plantas, o que acarreta em investimentos elevados sub-utilizados. A praticidade da utilização de uma modelagem de processo que possa ser "parametrizada" em uma linguagem similar ao raciocínio humano, por si só já torna a lógica nebulosa uma ferramenta poderosa na modelagem desse tipo de processo biológico.

Nesse sentido, este trabalho procurou avaliar o desempenho da utilização de tal ferramenta para a modelagem do comportamento da concentração de oxigênio dissolvido no tanque de aeração de um benchmark construído para a remoção de matéria carbonácea e nitrogenada. Com o intuito de testar a robustez da técnica, optou-se pela utilização de formas de modelagem nebulosa que não dispusessem de conhecimento prévio de um especialista. Foram então escolhidas a técnica de modelagem neuro-nebulosa (ANFIS) e a discretização nebulosa com regras limitadas.

A modelagem neuro-nebulosa, como os resultados mostrados no capítulo 4 podem demonstrar, indicou um desempenho melhor que a técnica de discretização nebulosa com regras limitadas. Tal constatação não se deve somente às menores somatórias dos erros quadráticos da modelagem ANFIS (a técnica de discretização nebulosa não apresentou resultados referentes às medidas de erro tão distantes da modelagem neuro-nebulosa), mas também à possibilidade de visualização das funções de 
pertinência de forma mais nítida e à maior velocidade de processamento do algoritmo à medida que se experimentava um maior número de variáveis de entrada $\mathrm{e}$ um maior número de clusters.

Observando-se os resultados do capítulo anterior, pode-se observar que a estrutura mais simples da modelagem ANFIS (1 regressor e 3 funções de pertinência por variável de entrada) deve ser adotada por representar a contento o comportamento da variável de saída, exigir menos esforço computacional e possuir um número de termos lingüísticos (3) razoável para a expressão do raciocínio humano.

É ainda importante ressaltar que a maldição da dimensionalidade observada em outros algoritmos de modelagem nebulosa também pode ser verificada na forma neuro-nebulosa, se a partir de um determinado número de variáveis de entrada, de clusters e de pontos de coleta de dados houver a utilização do modo "grid partition" para geração do modelo nebuloso inicial. Essa forma de geração do modelo nebuloso inicial trabalha com a totalidade de regras possíveis à estrutura do modelo. Para um número elevado de entradas, clusters e pontos, foi observado que a melhor forma de geração do modelo nebuloso inicial é o sub-clustering que otimiza o número de regras, estabelecendo uma quantidade otimizada de clusters igual ao número de regras.

O bom desempenho da utilização da lógica nebulosa para a modelagem da variável mais importante do processo de tratamento de esgotos por lodos ativados motiva um uso mais abrangente de tal técnica para o estabelecimento de modelos mais completos de tais plantas, ou mesmo o desenvolvimento de sensores virtuais de variáveis deste processo de forma a proporcionar uma redução dos gastos com a manutenção periódica da instrumentação correlata. Outra aplicação promissora que merece ser citada é a utilização de controle nebuloso dos processos unitários das plantas de tratamento de esgotos. 


\subsection{Perspectivas de trabalhos futuros}

A utilização de modelos de processos de tratamento de esgotos tem sido direcionada principalmente para a construção de simuladores que têm sido ferramentas eficientes para a otimização das estações de tratamento. Assim, evitando as técnicas de modelagem matemática tradicionais, seria importante o aprofundamento do estudo da modelagem nebulosa com suas variantes.

Outras técnicas de otimização dos parâmetros de modelos nebulosos têm sido empregadas como, por exemplo, algoritmos genéticos. A possibilidade de comparação de tais modelos com aqueles desenvolvidos neste trabalho seria de grande importância para se ter mais indicadores que medissem a robustez das estruturas destes últimos.

Aproveitando os modelos obtidos nesta dissertação, poder-se-ia ainda realizar o controle da variável de saída (concentração de oxigênio dissolvido) utilizando-se controle nebuloso e, assim, analisar o comportamento da iteração da modelagem e controle nebulosos.

Um trabalho que seria mais complexo, porém de grande interesse prático, seria a modelagem completa de uma estação de tratamento de esgotos por lodos ativados para remoção exclusiva de material carbonáceo, que é uma configuração de processo mais comum no Brasil. Tal modelagem poderia ter seus resultados comparados com simuladores de mercado que têm custo de aquisição elevado e são de difícil parametrização. Essa modelagem nebulosa não necessariamente deveria ser do tipo Takagi-Sugeno, podendo haver o aproveitamento do conhecimento dos operadores em uma experiência com a abordagem de Mamdani.

Além da modelagem total de uma estação de tratamento de esgotos, há o interesse crescente dos profissionais da área de saneamento pelo desenvolvimento de sensores virtuais. Tal fato se deve à necessidade de aquisição de dados de variáveis de processo que normalmente não estão disponíveis continuamente, seja pela ausência 
de instrumentação confiável, pelo seu elevado custo ou pela necessidade de uma limpeza freqüente. Como exemplos, podem ser citados os analisadores de DQO, $\mathrm{DBO}_{5}$ (cuja análise laboratorial demora 5 dias) e de amônia, entre outros. Mesmo parâmetros cinéticos que reflitam o comportamento de determinado tipo de microrganismo ao longo da estação poderiam ser estimados com base no conhecimento de especialistas. 


\section{Referências Bibliográficas}

1. AGUIRRE, L.A. Introdução à identificação de sistemas- Técnicas lineares e não-lineares aplicada a sistemas reais. Belo Horizonte: Editora UFMG, 2000.

2. AUBRUN, C.; THEILLIOL; D.; HARMAND, J.; STEYER, J.P. Software sensor design for COD in na anaerobic fluidized bed reactor. Water Science and Technology, v. 41, n.7, p. 115-120, 2001.

3. BABUSKA, R. (2001). Fuzzy systems, modelling and identification. http://lcewww.et.tudelft.nl/ babuska.

4. BECK, M.B. Identification, estimation and control of biological wastewater treatment processes. Proc. Inst. Elec. Eng., v.133, p.254-264, 1986.

5. CARVAlHO, A.L.; PENA, R.T.; BRAGA, A.P.; CHERNICHARO, C.A.L. Utilização de técnicas neurais para modelagem de um reator UASB. In: CONGRESSO BRASILEIRO DE ENGENHARIA SANITÁRIA E AMBIENTAL, $20^{\circ}$, Rio de Janeiro, Anais, p.875-884, 1999. 1 CD-ROM.

6. CATUNDA, S.Y.C.; DEEP, G.S.; VAN HAANDEL, A.C.; FREIRE, R.C.S. Métodos alternativos para medição da taxa de consumo de oxigênio em sistemas de lodo ativado. SBA Controle \& Automação, v.9, n.2, Maio/Junho/Julho/Agosto, 1998.

7. CHAN, J.; ATKINSON, J.; PELZER, M.; SAVARA, A. Advanced process control technical papers- St. Marys sewage treatment plant. Sidney, 1987. 
8. CHENG, C.Y.; RIBAROVA, I. Activated sludge system modelling and simulations for improving the effluent water quality. Water Research, v.39, n.8, p. 93-98, 1999.

9. DUNN, I. J.; HEINZLE E.; INGHAM, J. e PRENOSIL, J. E. Biological Reaction Engineering. Weinheim: VCH, 1992.

10. GHAVIPANJEH, F.; TAYLOR, C.J.; YOUNG, P.C.; CHOTAI, A. Data-based modelling and proportional-integral-plus(pip) control of nitrate in an activated sludge benchmark. Water Science and Technology, v.44, n.1, p.87-94, 2001.

11. HASSELBLAD , S.; BJÖRLENIUS; CARLSSON, B. Use of dynamic models to study secondary clarifier performance. Water Science and Technology, v.37, n.12, p.207-212, 1998.

12. HELLENDOORN, H; DRIANKOV, D. Fuzzy model identification-selected approaches. Munich: Springer, 1997.

13. HENZE, M.; GRADY, C.; GUJER, W.; G. MARAIS, G.v.R.; MATSUO, T. Activated sludge model $\mathbf{N}^{\circ}$. 1. IAWPRC Scientific and Technical Report $\mathrm{N}^{\mathrm{O}} .1$, IAWPRC Task Group on Mathematical Modelling for Design and Operation of Biological Wastewater Treatment, London, IAWPRC, p.33, 1987.

14. JANG, J. S. R. ANFIS: Adaptive-Network-Based Fuzzy Inference System. IEEE Transactions on Systems, Man, and Cybernetics, v.23, n.3, p. 665-685, May/June, 1993.

15. JEPPSSON, U. Modelling aspects of wastewater treatment processes. 1996. $\mathrm{PhD}$ thesis. Lund Institute of Technology. Lund, Sweden. 
16. JEPPSSON, U.; OLSSON, G. Reduced order models for on-line parameter identification of the activated sludge process. Water Science and Technology, v.28, n.11-12, p.173-183, 1993.

17. JULIEN, S.; BABARY, J.P.; LESSARD, P. Theoretical and practical identifiability of a reduced order model in an activated sludge process doing nitrification and denitrification. Water Science and Technology, v.37, n.12, p.309-316, 1998.

18. KETCHEN, S. Wastewater modelling can analyze treatment perfomance. Environmental Science \& Engineering Magazine, March, 1997.

19. LANT, P.A.; STEFFENS M.A. Benchmarking for process control: "should I invest in improved process control?". Water Science and Technology, 21, 37 (12), pp. 49-54, 1998.

20. LINDBERG, C.F. Control and estimation strategies applied to the activated sludge process. 1997. PhD thesis. Department of Materials Science-Systems and Control Group. Uppsala University, Uppsala, Sweden.

21. LJUNG, L. System identification, theory for the user. New Jersey: Prentice Hall, 1987.

22. MARSILI-LIBELLI, S.; GIOVANNINI, F. On-line estimation of the nitrification process. Water Res., v.31, n.1, p.179-185, 1997.

23. MATHWORKS. Simulink v2.2- A program for simulating dynamic system, and Matlab v.5.2- The language of technical computing. Natick, MA: The MathWorks Inc., 1998.

24. NOLASCO, D.; HELOU, L.C. (1998). Emprego de modelos dinâmicos em projetos e otimização de estações de tratamento de águas residuárias. 
Engenharia Sanitária e Ambiental, v.3, n.3, Julho/Setembro e n.4, Outubro/Dezembro, p. 107-112, 1998.

25. NOLASCO, D., STEPHENSON, J. e DE ANGELIS, B. Maximizing the use of existing facilities at Metro Toronto's Main Treatment Plant using the process audit approach. Environment Science \& Engineering, June/July, 1994.

26. OLSSON, G. Advancing ICA technology by eliminating the constraints. Water Science and Technology, v.28, n.11-12, p.1-7, 1993.

27. QUEINNEC, I.; DOCHAIN, D. Modelling and simulation of the steady-state of secondary settlers in wastewater treatment plants. Water Science and Technology, v.43, n.7, p. 39-46, 2001.

28. SAMPAIO, A.O.; GONÇALVES, M.C. Custos operacionais de estações de tratamento de esgoto por lodos ativados: Estudo de caso ETE- Barueri. In: CONGRESSO BRASILEIRO DE ENGENHARIA SANITÁRIA E AMBIENTAL, $20^{\circ}$, Rio de Janeiro, Anais, p.676-685, 1999. 1 CD-ROM.

29. SHAW, I.S.; SIMÕES, M.G. Controle e modelagem fuzzy. São Paulo: Edgard Blücher/FAPESP, 1999.

30. SOTOMAYOR, O.A.Z. Modelagem, identificação e controle de sistemas de tratamento de lodo ativado. 2002. Tese de doutorado. Escola Politécnica da Universidade de São Paulo, São Paulo, Brasil.

31. SOTOMAYOR, O.A.Z.; Park, S.W.; GARCIA, C. Recursive identification of activated sludge wastewater treatment plants. In: IFAC System Identification, Santa Barbara, 2000. 
32. SOTOMAYOR, O.A.Z.; PARK, S.W.; GARCIA, C. A general benchmark for simulation of innovating control strategies in biological wastewater treatment. Brazilian Journal of Chemical Engineering, v.18, n.1, p. 81-101, 2001.

33. TAKÁCS, I.; PATRY, G.G.; NOLASCO, D.A. A dynamic model of clarification-thickening process. Water Research, v.25, n.10, p.1263-1271, 1991.

34. TAKAGI, T.; SUGENO, M. Fuzzy identification of systems and its applications to modelling and control. IEEE Transactions on Systems, Man, and Cybernetics, v.. SMC-15, n.1, p. 116-132, January/February, 1985.

35. VAN HAANDEL, A.; MARAIS, G. O comportamento do sistema de lodo ativado. Campina Grande: UFPB, 1999.

36. VANROLLEGHEM, P.; JEPPSON, U., CARSTENSEN, J., CARLSSON, B. e OLSSON, G. Integration of WWT plant design and operation: a systematic approach using cost functions. Water Science \& Technology, v.34, n.3-4, p.159171,1996

37. VON SPERLING, M. Princípios do tratamento biológico de águas residuárias. Belo Horizonte: DESA, UFMG, 1997.

38. WANG, L.; LANGARI, R. Complex systems modeling via fuzzy logic. IEEE Transactions on Systems, Man, and Cybernetics- Part B: Cybernetics, v.26, n.1, p. 100-106, February, 1996. 